\title{
TONI RICARDO MARTINS
}

Citologia líquida e teste molecular para HPV de alto risco: avaliação de novas modalidades de rastreio para prevenção de câncer de colo do útero na rede pública de Saúde do Estado de São Paulo

Tese apresentada à Faculdade de Medicina da Universidade de São Paulo para obtenção do título de Doutor em Ciências

Programa de: Doenças Infecciosas e Parasitárias

Orientador: Dr. José Eduardo Levi 
Dados Internacionais de Catalogação na Publicação (CIP)

Preparada pela Biblioteca da

Faculdade de Medicina da Universidade de São Paulo

Creprodução autorizada

Martins, Toni Ricardo

Citologia líquida e teste molecular para HPV de alto risco : avaliação de novas modalidades de rastreio para prevenção de câncer de colo do útero na rede pública de saúde do Estado de São Paulo / Toni Ricardo Martins. -- São Paulo, 2016.

Tese(doutorado)--Faculdade de Medicina da Universidade de São Paulo.

Programa de Doenças Infecciosas e Parasitárias.

Orientador: José Eduardo Levi.

Descritores: 1.Neoplasias do colo do útero 2.Citologia líquida 3.Teste molecular para HPV 4.Rastreio 5.Prevenção

USP/FM/DBD-488/16 
Dedicatória 
Dedico este trabalho às mulheres com câncer de colo do útero, incansáveis na luta diária pela cura; em especial, a todas mulheres que contribuíram para que este estudo fosse possível. 
Agradecimentos 
Ao meu orientador, Dr. José Eduardo Levi, por acreditar em mim e me dar a oportunidade de realizar este trabalho tão importante, além da amizade nesta etapa de mudança e crescimento profissional e pessoal. Minha especial gratidão, obrigado pelo desafio! Admiro seu exemplo de dedicação à pesquisa, OBRIGADO Dudi!

Ao Prof. Dr. José Eluf Neto, que me acolheu na Fundação Oncocentro de São Paulo. Agradeço a confiança e a oportunidade de colaborar em seu projeto.

À Diane Dede Cohen, meu especial agradecimento pela ajuda em todas as etapas do desenvolvimento deste trabalho, pela brilhante coordenação de campo e por tornar mais alegre e otimista a espera pelo desfecho de todas as etapas, uma grande pessoa e amiga!

Ao Prof. Dr. Claudio Sérgio Pannuti e a Dra. Clarisse Martins Machado, pela acolhida no Laboratório de Virologia do IMT-USP.

À toda equipe da FOSP: Luiz Mário também amigo de Pós Graduação, Lise, Mércia, Meire, Sueli, Kléber, Sandra, Adriana, Gislene, Angélica, Cidinha e demais colaboradores que tornaram possível a realização deste projeto.

Ao Dr. Adhemar Longatto Filho e a Dra. Luisa Lina Villa pela acolhida neste estudo.

Á Juliana Yukari Kodaira Viscondi pela ajuda nos cálculos estatísticos do projeto. 
À Ana Carolina Soares de Oliveira, um especial agradecimento pelo convívio, amizade, auxílios, conversas, aprendizados, um exemplo de dedicação, de pesquisadora, de pessoa, que desde o início acompanhou esta caminhada.

Aos amigos Thiago e Célia pelo convívio, por terem me recebido tão bem no Laboratório de Virologia do IMT-USP.

Ao grupo do HPV do Laboratório de Virologia do IMT-USP, Luciana, Cristina e Cristiane.

Aos colegas do Laboratório de Virologia do Instituto de Medicina Tropical da USP pelas conversas, auxílio e convivência, em especial o Charlys, Luiz, Felipe, Paulo, à Camila, Cristina Fink, Lucy, Laura e Cynthia.

Ao Luciano Monteiro Silva e Sônia Ferraz, pelos exemplos de dedicação ao trabalho e por estarem sempre dispostos a ajudar.

Aos demais colegas do Laboratório de Virologia do Instituto de Medicina Tropical da USP pelo convívio e fazerem do nosso laboratório um ambiente agradável.

A todas equipes de profissionais das Unidades Básicas de Saúde envolvidos, que contribuíram para que este projeto fosse possível. 
Aos Prof. Dr. Aluisio Segurado, Prof. Dr. Sérgio Mancini Nicolau e Profa. Dra. Thaís Heinke, membros examinadores da Banca de Qualificação, pelas valiosas sugestões e correções.

Ao Prof. Dr. Heitor Franco de Andrade Junior, por ter aceitado ser meu supervisor no Programa de Aperfeiçoamento de Ensino (PAE) da FMUSP.

À Profa. Dra. Maria Luiza Bazzo da Universidade Federal de Santa Catarina pelo apoio na vinda para São Paulo, incentivo imprescindível para que este caminho se tornasse possível.

À Coordenação do Programa de Doenças Infecciosas e Parasitárias da FMUSP, pelo apoio prestado, pela possibilidade de participação no Eurogin 2016 (International Multidisciplinary Congress), Salzburg, Áustria.

Às secretárias do Programa de Pós-Graduação em Doenças Infecciosas e Parasitárias, Roseli e Letícia pelo suporte oferecido.

Aos meus pais, Antônio e Irene, pela formação moral e acadêmica que me proporcionaram e pelo exemplo de vida. Obrigado por todo amor, incentivo, apoio em minhas escolhas e por acreditarem sempre em minha vitória.

À minha filha Bettina, que neste período de distância sempre me apoiou, me ouviu, me entendeu e ensinou tantas coisas, obrigado Be, é por você que também estou aqui. 
Às minhas irmãs Karla e Rafaela, aos meus sobrinhos Kaio, Luna e Gaia, e ao Cyro pelo companheirismo e incentivo.

À Congregação das Irmãzinhas da Imaculada Conceição, em especial à Irmã Leodi Bolzan pela acolhida na chegada em São Paulo, tornando possível a realização deste objetivo.

Ao amigo Marlon Flôr pelas conversas e convívio durante este período.

À Coordenação de Aperfeiçoamento de Pessoal de Nível Superior (CAPES) pela concessão da bolsa de doutorado.

Ao INCT - HPV pela contribuição no financiamento deste projeto e por tornar possível minha participação no Eurogin 2016 (International Multidisciplinary Congress), Salzburg, Áustria.

À FAPESP 2008/57889-1 e CNPQ 573799/2008 pela contribuição no financiamento deste projeto.

À BD (Becton, Dickinson and Company) pelo financiamento deste estudo, suporte e possibilidade de participação no Eurogin 2016 (International Multidisciplinary Congress), Salzburg, Áustria.

Por fim, meu agradecimento a todos que, direta ou indiretamente, colaboraram para a realização deste trabalho. 
Epígrafe 
"Já ancorado na Antártica, ouvi ruídos que pareciam de fritura. Pensei: Será que até aqui existem chineses fritando pastéis? Eram cristais de água doce congelada que faziam aquele som quando entravam em contato com a água salgada. O efeito visual era belíssimo. Pensei em fotografar, mas falei pra mim mesmo - Calma, você terá muito tempo para isso... Nos 637 dias que seguiram o fenômeno não se repetiu. As oportunidades são únicas”. 
Normatização adotada 
Esta tese está de acordo com as seguintes normas, em vigor no momento de sua publicação:

Referências: adaptado de International Committee of Medical Journals Editors (Vancouver).

Universidade de São Paulo. Faculdade de Medicina. Divisão de Biblioteca e Documentação. Guia de apresentação de dissertações, teses e monografias. Elaborado por Anneliese Carneiro da Cunha, Maria Julia de A.L.Freddi, Maria F.Crestana, Marinalva de Souza Aragão, Suely Campos Cardoso, Valéria Vilhena. $3^{\underline{a}}$ ed. São Paulo: Divisão de Biblioteca e Documentação; 2011.

Abreviatura dos títulos e periódicos de acordo com List of Journals Indexed in Index Medicus. 
Sumário 
Lista de siglas e abreviaturas

Lista de símbolos

Lista de figuras

Lista de tabelas

Lista de gráficos

Resumo

Abstract

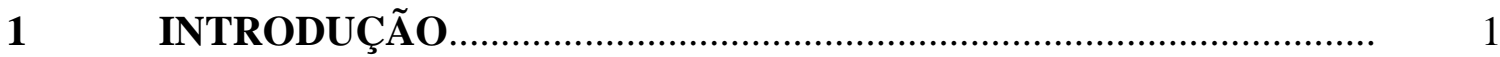

$2 \quad$ REVISÃO DA LITERATURA..................................................................... 7

2.1 HPV um breve histórico................................................................. 8

2.1.1 Classificação, Biologia e Nomenclatura dos HPVs.................................. 8

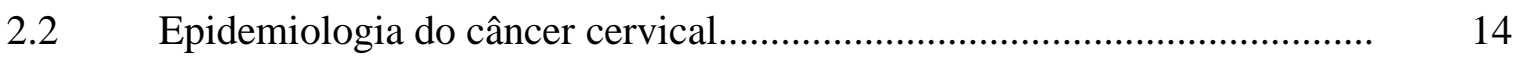

2.3 História natural das infecções pelo hpv, câncer cervical e suas lesões

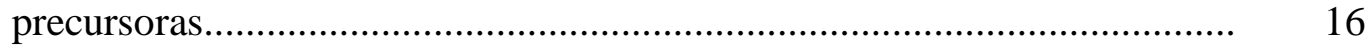

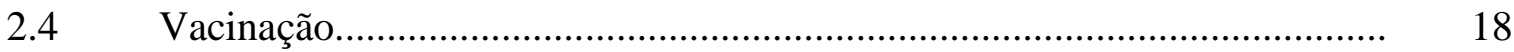

2.5 Métodos de detecção e tipagem do hpv........................................................ 19

2.5.1 Diagnóstico Morfológico do HPV ……...................................................... 19

2.5.1.1 Método de rastreamento: Citologia Oncótica ou Citopatologia................... 20

2.5.1.2 Citologia em base Líquida (LBC) ......................................................... 22

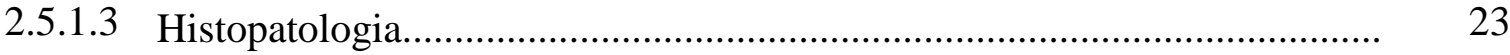

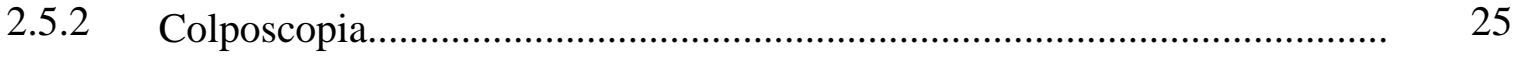

2.5.3 Diagnóstico molecular do HPV ............................................................... 26

2.5.3.1 Teste de Amplificação de sinal - Captura de Híbridos................................ 27

2.5.3.2 Testes com base em PCR (Polymerase Chain Reaction)............................ 29

2.5.3.3 PCR em tempo real.......................................................................... 31

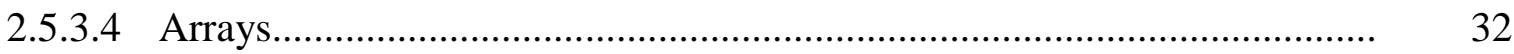

2.5.3.5 Detecção do RNA mensageiro viral para as oncoproteínas E6 e E7 (E6/E7 mRNA) - NASBA (Nucleic Acid Sequence Based Amplification).............. 33

2.5.3.6 Hibridização in situ.................................................................................. 34

2.6 Uso dos testes de HPV no rastreio primário do câncer cervical................... 34

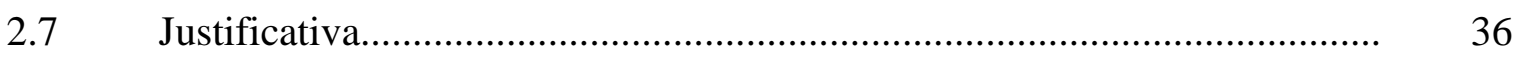

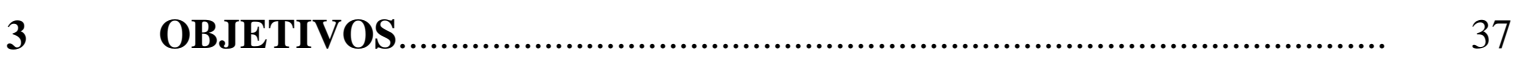

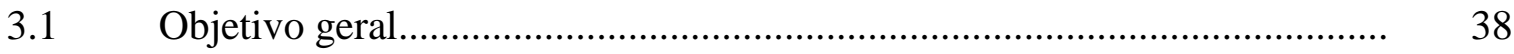


3.2 Objetivos específicos.......................................................................... 38

4. MATERIAL E MÉTODOS.................................................................. 39

$4.1 \quad$ Metodologia ................................................................................... 40

4.2 Comitê de Ética..................................................................................... 40

4.2.1 Registro internacional............................................................................ 40

4.3 Amostragem e critérios de inclusão............................................................. 40

4.4 Coleta e preparo das amostras citológicas................................................. 41

4.5 Avaliação pelo BD FOCALPOINT TM GS...…………………………...... 43

4.5.1 Classificação das citologias........................................................................... 43

4.5.1.1 Discrepâncias de classificação.....................................................................

4.5.2 Teste molecular para HrHPV ..................................................................... 44

4.5.2.1 BD Onclarity HPV Assay (BD Diagnostics, Sparks,MD)®.............. 44

4.5.2.2 Preparo das amostras............................................................................... 45

4.5.2.3 Extração, amplificação e detecção..............................................................

4.6 Colposcopia............................................................................... 4

$4.7 \quad$ Biópsia........................................................................................ 48

$4.8 \quad$ Fluxograma metodológico........................................................................ 49

4.8.1 Mulheres com 25 anos ou mais................................................................... 49

4.8.2 Mulheres com menos de 25 anos .............................................................. 50

$4.9 \quad$ Estratégias de rastreamento do câncer cervical............................................ 51

4.10 Análise estatística e avaliação do algoritmo................................................. 52

$5 \quad$ RESULTADOS...................................................................................... 54

5.1 Amostras por Unidade de Saúde................................................................... 55

5.2 Avaliação da amostra e junção escamo colunar por unidade......................... 56

5.3 Citologia oncótica ou citopatologia............................................................. 58

$5.4 \quad$ Teste de HrHPV ................................................................................ 59

$5.5 \quad$ Tipos de HPV e citologia oncótica........................................................... 63

5.6 Focal point e distribuição das infecções simples e coinfecção pelo HPV.... 65

$5.7 \quad$ HPV e escolaridade..................................................................................... 67

$5.8 \quad$ HrHPV, citologia, colposcopia e biópsia...................................................... 68

5.9 Comparação de estratégias (algoritmos) de rastreio e triagem tendo como desfecho os casos NIC 2+................................................................ $\quad 75$

5.10 Comparação de estratégias (algoritmos) de rastreio e triagem tendo como 86 
desfecho os casos NIC $3+$

6.1 Citologia oncótica e HrHPV.

6.2 Comparação de estratégias (algoritmos) de rastreio do câncer de colo do útero incorporando diferentes combinações de citologia, teste de hpv e

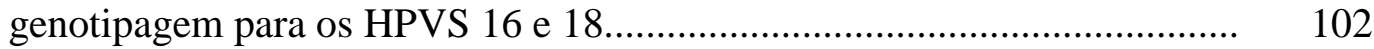

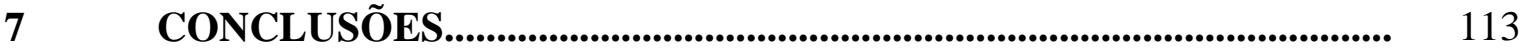

7.1 Sumário dos resultados........................................................................ 115

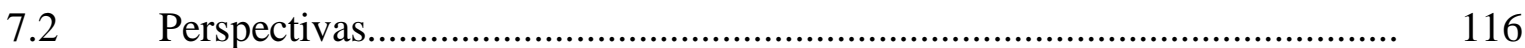

7.3 Participação do aluno e produção científica............................................... 117

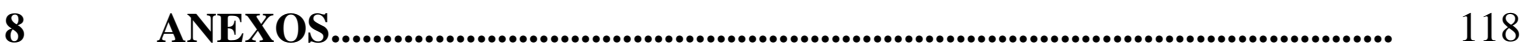

$9 \quad$ REFERÊNCIAS BIBLIOGRÁFICAS...................................................... 135

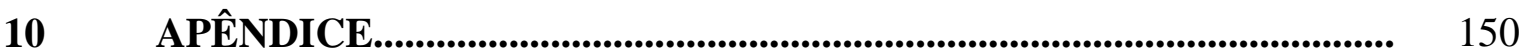


Listas 


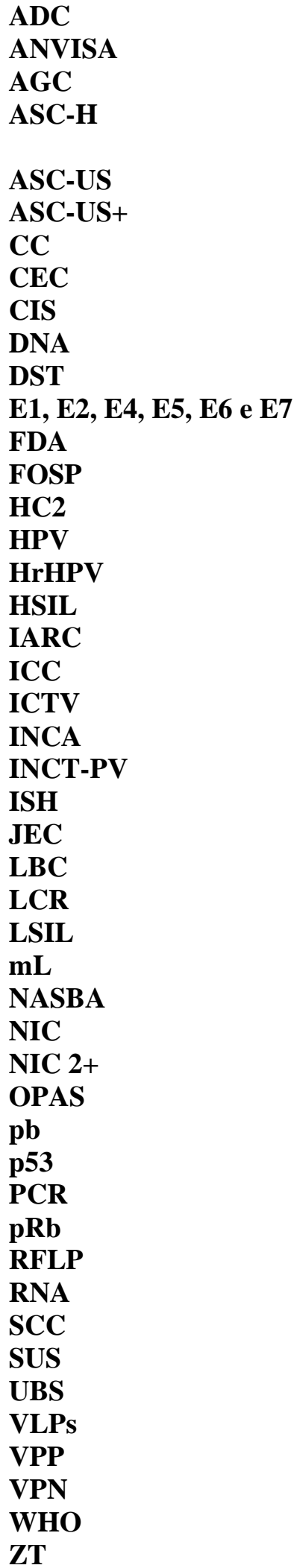

Adenocarcinoma

Agência Nacional de Vigilância Sanitária

Células Glandulares Atípicas

Células Escamosas Atípicas, não se pode excluir lesão intra-epitelial escamosa de alto grau

Células Escamosas Atípicas de Significado Indeterminado

Células Escamosas Atípicas de Significado Indeterminado ou anormalidade maior

Câncer Cervical

Carcinoma Epidermóide Invasor

Carcinoma in situ

Ácido Desoxiribonucléico

Doença Sexualmente Transmissível

E1, E2, E4, E5, E6 e E7 - Early regions 1-7 ou Regiões precoces 1-7

Food and Drug Administration

Fundação Oncocentro de São Paulo

Captura Híbrida versão 2

Papilomavírus Humano

Papilomavírus Humano de Alto Risco

Lesão Escamosa Intraepitelial de Alto Grau, inclui Ca in situ

International Agency for Research on Cancer

Invasive Cervical Cancer

International Committee on the Taxonomy of Viruses

Instituto Nacional do Câncer

Instituto Nacional de Ciência e Tecnologia das Doenças dos Papilomavírus

Hibridização Molecular in situ

Junção Escamo Colunar

Citologia em Base Líquida

Long control region ou Região regulatória

Lesão Escamosa Intraepitelial de Baixo Grau

Mililitro

Nucleic Acid Sequence Based Amplification

Neoplasia Intraepitelial Cervical

Neoplasia Intraepitelial Cervical grau 2 ou lesão de grau maior

Organização Pan-Americana da Saúde

Pares de bases

Gene supressor tumoral

Reação em Cadeia da Polimerase

Gene do Retinoblastoma

Restriction Fragment Lenght Polymorphism

Ácido Ribonucleico

Squamous Cell Carcinoma

Sistema Único de Saúde

Unidade Básica de Saúde

Vírus-like particles

Valor Preditivo Positivo

Valor Preditivo Negativo

World Health Organization - Organização Mundial de Saúde

Zona de Transformação 
$\% \quad$ Percentagem

${ }^{\mathbf{0}} \mathrm{C}$ Graus Celsius

$\boldsymbol{\mu L} \quad$ Microlitro 
Tabela 1 Distribuição dos resultados citológicos por faixa etária.

Tabela 2 Distribuição dos resultados das 15.945 amostras para o DNA do HPV segundo a classificação na citologia oncótica.......................................... 60

Tabela 3 Número de tipos de HPV detectados segundo a classe citológica............. 67

Tabela 4 Diagnóstico histológico de acordo com a faixa etária............................... 70

Tablea 5 Distribuição dos HPVs 16 e 18 e demais HrHPVs de acordo com a classificação histológica.

Tabela 6 Perfil das amostras NIC 2+ observadas no estudo de acordo com os testes molecular e citológico

Tabela 7 Estimativas das razões de chances para Lesões de Alto Grau de acordo com o resultado do teste de HPV

Tabela 8 Resultados das diferentes estratégias para a detecção de NIC 2+... 79

Tabela 9 Número de colposcopias e sensibilidade para NIC 2+ das diferentes estratégias utilizadas

Tabela 10 Resultados das diferentes estratégias para a detecção de NIC 3+ 87 
Figura 1 Representação esquemática do genoma do HPV .............................. 9

Figura 2 Esquema representativo dos gêneros do HPV e seus tipos. ................ 12

Figura 3 Ilustração do ciclo celular da infecção e principais etapas do ciclo do HPV

Figura 4 Representação das taxas brutas de incidência de câncer do colo do útero por 100 mil mulheres, estimadas para o ano de 2016 segundo Unidade da Federação.

Figura 5 Fluxo das amostras no laboratório da FOSP após processamento pelo Sistema BD Totalys

Figura 6a Distribuição dos 14 tipos de HrHPV para detecção na placa de PCR.

Figura 6b Demonstração da placa de PCR utilizada no ensaio BD Onclarity HPV

Figura 7 Esquema de seleção de amostras para o cálculo da razão de chances (odds ratio) de acordo com os genótipos 16, 18 e demais HrHPVs para os casos de NIC $2+$

Figura $8 \quad$ Estratégia 1 - HPV isolado........................................................... 81

Figura $9 \quad$ Estratégia 2 - Citologia isolada...................................................... 81

Figura 10 Estratégia 3 - Coteste com corte em ASC-US................................... 82

Figura 11 Estratégia 4-Citologia ASC-US com teste reflexo de HPV.............. 82

Figura 12 Estratégia 5 - HPV (+) seguido de triagem citológica........................ 83

Figura 13 Estratégia 6 - HPV com genotipagem 16/18 ................................. 83

Figura 14 Estratégia 7 - Genotipagem 16 e $18+$ demais HrHPVs $\rightarrow$ Cito, corte em $\geq$ ASC-US

Figura 15 Estratégia 8 - Genotipagem 16 e $18+$ demais HrHPVs $\rightarrow$ Cito, corte em > ASC-US

Figura 16 Estratégia 9 - Citologia preconizada no Brasil................................. 85

Figura 17 Estratégia 10 - Citologia preconizada no Brasil 25 a 64 anos............. 85

Figura 18 Estratégia 3 - Genotipagem 16 e $18+$ demais HrHPVs $\rightarrow$ Cito, corte em $\geq$ ASC-US. 
Gráfico 1 Distribuição das 15.991 amostras colhidas por Unidade de Saúde...... 56

Gráfico 2 Distribuição da presença de células da JEC por Unidade de Saúde em 15.945 amostras.................................................................. 57

Gráfico 3 Distribuição da presença de células da JEC por faixa etária em 57 15.945 amostras.

Gráfico 4 Frequência dos tipos de HPVs identificados em 15.991 amostras....... 61

Gráfico 5 Presença do DNA do HPV estratificados por faixa etária em 15.991 mulheres analisadas no estudo.................................................... 62

Gráfico 6 Distribuição dos genótipos de HPV de acordo com as faixas etárias.......

Gráfico 7 Distribuição dos tipos de HPV de acordo com a classificação citológica em 15.945 amostras........................................................... 65

Gráfico 8 Distribuição das classes citológicas de acordo com os quintis do Focalpoint......

Gráfico 9 Distribuição dos grupos positivos e negativos para o DNA do HPV de acordo com a variável escolaridade.

Gráfico 10 Sensibilidade para NIC 2+ e número de colposcopias requeridas de acordo com cada estratégia utilizada. 
Resumo 
Martins TR. Citologia líquida e teste molecular para HPV de alto risco: avaliação de novas modalidades de rastreio para prevenção de câncer de colo do útero na rede pública de saúde do Estado de São Paulo [Tese]. São Paulo: Faculdade de Medicina, Universidade de São Paulo; 2016.

Introdução/Objetivos: Anualmente são estimados cerca de 16.000 novos casos de câncer de colo do útero no Brasil. As novas tecnologias podem levar a uma redução deste número, permitindo não só uma expansão da população abrangida pelo rastreio, mas também melhorando a taxa de detecção de lesões precursoras. Casuística e Métodos: Mulheres com idade entre 12 e 90 anos provenientes de duas regiões da cidade de São Paulo, rotineiramente realizando seus exames citopatológicos e histopatológicos com a FOSP, foram recrutadas para este estudo no período de dezembro de 2014 até março de 2016, totalizando 15.991 amostras. As amostras foram transportadas para a FOSP onde foram submetidas paralelamente ao teste Onclarity para DNA de HPV de alto risco (HrHPV) e citologia em base líquida (LBC), ambos produtos da empresa BD (Becton-Dickinson, EUA). O ensaio BD Onclarity® HPV detecta 14 genótipos de alto risco, com identificação individual dos tipos 16, 18, 31, 45, 51, 52 e os demais tipos em três grupos distintos: P1 (HPVs 33, 58); P2 (HPVs 56, 59, 66) e P3 (HPVs 35,39,68). Mulheres com resultado citológico ASC-US ou superior e/ou positivas para HrHPV foram encaminhadas para a colposcopia e eventual biópsia a critério médico. Resultados: Entre as 15.991 amostras analisadas, 15.945 (99,7\%) foram satisfatórias para a citologia, destas 7,2\% (1.152/15.945) apresentaram alguma anormalidade e foram classificadas como positivas, da seguinte forma: ASC-US 546 (3,4\%); ASC-H 119 (0,7\%); LSIL 392 (2,5\%); HSIL 87 (0,5\%), dois casos $(0,01 \%)$ de CEC e seis $(0,04 \%)$ de AGC. O teste molecular para a pesquisa do HrHPV mostrou $2.398(15 \%)$ amostras positivas. O DNA do HPV foi detectado em $12,1 \%$ das citologias classificadas como negativas, em 31,1\% dos casos de ASC-US; $58,8 \%$ de ASC-H; 73,2\% de LSIL; 87,4\% dos casos de HSIL, nas duas amostras classificadas como CEC e em 16,7\% das AGC. Os tipos de HPVs mais frequentes foram representados pelo grupo P3 em 3,8\% das amostras seguidos do grupo P2 em 3,6\%; HPV 16 (3,2\%); HPV 52 (2,4\%); grupo P1 (2,3\%); HPV 31 (1,9\%); HPV $51(1,4 \%)$; HPV $18(1,2 \%)$ e HPV $45(0,9 \%)$. Pelo protocolo, $2.309(14,4 \%)$ amostras foram encaminhadas para a colposcopia e destas $1.287(55,7 \%)$ realizaram o procedimento. Trezentos e trinta e quatro foram biopsiadas, revelando 147 (44\%) resultados histopatológicos alterados, distribuídos da seguinte forma: 75 (51\%) casos de NIC 1; 59 $(40,1 \%)$ de NIC 2; sete $(4,8 \%)$ de NIC 3; dois $(1,4 \%)$ de Carcinomas in situ; dois $(1,4 \%)$ de Carcinomas epidermóides invasivos (CEC) e dois $(1,4 \%)$ de Adenocarcinomas. O DNA do HPV foi detectado em 98,6\% (71/72) dos casos de NIC $2+$, destes, 18 apresentaram citologias negativas, incluindo um adenocarcinoma. Entre os casos de NIC $3+(\mathrm{N}=13)$, o HrHPV foi detectado em 100\% sendo o HPV 16 o mais frequente, presente em 53,8\% (7/13) enquanto a citologia foi negativa em dois destes. Conclusões: $O$ teste de DNA do HPV detectou um número significativo de pacientes com lesões pré-malignas não detectadas por citologia. Ainda, a citologia forneceu uma classificação que de acordo com o algoritmo atual, atrasaria a detecção de NIC2 + devido a adição de um ciclo de citologia repetida em 6 meses - 1 ano. Se for adotado o rastreamento por DNA do HPV, de modo a evitar um aumento na demanda de exames colposcópicos, será muito importante adicionar um marcador de valor preditivo positivo elevado às amostras HrHPV+ antes de referir à colposcopia. O limite inferior de idade de 30 anos para o rastreamento baseado em HPV empregado na Europa provavelmente 
não é ideal para o Brasil, onde não é incomum observar-se mulheres jovens com NIC 2 +. As taxas de NICs verificadas permitiram uma avaliação robusta dos ensaios, algoritmos e estratégias de gestão. O uso da genotipagem 16/18 e triagem citológica para os demais HrHPVs forneceu um equilíbrio entre sensibilidade e especificidade, número de testes e colposcopias requeridas para detecção de NIC $2+$, e pode ser uma alternativa de uso combinado dos dois testes. A implantação na rede pública é viável mas deve ser previamente analisada sua custo-efetividade.

Descritores: neoplasias do colo do útero; citologia líquida; teste molecular para HPV; rastreio; prevenção. 
Abstract 
Martins TR. Liquid based cytologyand molecular testing for high-risk HPV: evaluation of new screening modalities for cervical cancer prevention in the Public Health System of the Sao Paulo State [Thesis]. São Paulo: "Faculdade de Medicina, Universidade de São Paulo"; 2016.

Background / Objectives: Every year there are approximately 16,000 new cases of cervical cancer in Brazil. New technologies may lead to a reduction of this number by allowing an expansion of the screening covered population but also by improving the detection rate of precursor lesions. Methods: Women participating in a routine CC primary screening program were invited to enroll in this study. An LBC sample was collected in SurePath medium and transported to Fundação Oncocentro where BD Totallis prepared, in parallel, slides for cytology and an aliquot for the BD Onclarity ${ }^{\mathrm{TM}}$ HPV Assay (HrHPV). A positive HrHPV test and/or cytology class > ASC-US referred the patient to colcoscopic examination and biopsy, if found necessary by the clinican. Results: In between December 2014 and March 2016 15,991 women joined this study. Among samples analyzed, 15,945 (99.7\%) were satisfactory for cytology, of these $7.2 \%$ $(1,152 / 15,945)$ had some abnormality and were classified as positive, as follows: ASCUS 546 (3.4 \%); ASC-H 119 (0.7\%); LSIL 392 (2.5\%); HSIL in 87 (0.5\%), two cases $(0.01 \%)$ of ICC and six $(0.04 \%)$ of AGC. HPV DNA testing showed 2,398 (15\%) positive samples, detected in $12.1 \%$ of the samples cytology classified as NILM, in $31.1 \%$ of ASC-US cases; $58.8 \%$ ASC-H; $73.2 \%$ LSIL; $87.4 \%$ of the cases of HSIL, in $100 \%$ samples classified as ICC and in $16.7 \%$ of the AGC. The most frequent HPV types were represented by the $\mathrm{P} 3$ group in $3.8 \%$ of these, followed by the $\mathrm{P} 2$ group in $3.6 \%$; HPV 16 (3.2\%); HPV 52 (2.4\%); P1 group (2.3\%); HPV 31 (1.9\%); HPV51 (1.4\%); HPV $18(1.2 \%)$ and HPV $45(0.9 \%)$. By protocol, 2,309 (14.4\%) were referred to colposcopic study and 1,287 (55.7\%) submitted to the procedure. Of these 334 samples were biopsied, revealing 147 (44\%) positive results distributed as follows: 75 (51\%) cases of CIN 1; 59 (40.1\%) of CIN 2; 7 (4.8\%) of CIN 3; 2 (1.4\%) SCC; 2 $(1.4 \%)$ of ICC and $2(1.4 \%)$ of adenocarcinomas. HrHPV was detected in $98.6 \%$ (71/72) cases of CIN $2+$, of these, 18 were negative by cytology, including an adenocarcinoma and was present in $100 \%$ of the 13 cases of CIN 3+, whereas cytology missed two of them. Among CIN3+ cases HPV 16 was the most frequent type, found in 53.8\% (7/13). Conclusions: HPV DNA testing detected a significant number of patients with premalignant lesions missed by cytology. In another fraction, cytology provided a classification that would, according to the current algorithm, delay the CIN2+ detection due to a loop of repeating cytology in 6 mo - 1 year. If HPV DNA screening is to be adopted, it will be a challenge to avoid an increase in the need for colposcopic examinations. Towards that, it will be very important to add one marker of high positive predictive value to HrHPV+ samples, before referral and analyzed in the same primary cervical smear. The European age cut-off of 30 yo for HPV basedscreening is probably not ideal in Brazil, where is not uncommon to observe young women with CIN2+. The CIN rate allowed a thorough evaluation of the assays and management strategies. The use of 16/18 HPV genotyping and cytological triage for the other HrHPVs provided a balance between sensitivity and specificity, number of tests and colposcopies required for detection of CIN 2+. The implementation in the public health system is feasible upon a positive cost effectiveness evaluation.

Descriptors: uterine cervical neoplasms; liquid cytology; molecular testing HPV-DNA, screening; prevention. 
1. Introdução 
Em contraste com a melhora geral da situação socioeconômica da população brasileira nos últimos anos, patologias que são características de uma deficiente assistência à saúde persistem (Schmidt et al., 2011). Entre elas, o câncer cervical (CC) é emblemático, um tema de grande relevância por sua alta incidência e elevadas taxas de mortalidade, ainda representa um grave problema de saúde pública em países em desenvolvimento, onde ocorrem oitenta por cento desses óbitos (Ferlay et al., 2008). O Instituto Nacional do Câncer (Inca), órgão do Ministério da Saúde no Brasil responsável pelo combate ao câncer, estimou que em 2016 ocorreriam 16.340 mil novos casos de câncer do colo uterino (Inca, 2016).

Globalmente, a maior parte dos programas de rastreio de câncer cervical (CC) usa o teste citológico (Papanicolaou) como ferramenta primária de prevenção. O Papanicolaou convencional tem uma história vitoriosa no decréscimo da incidência e mortalidade do $\mathrm{CC}$, e constitui o teste de rastreamento com a maior contribuição para o controle de um câncer específico - estima-se em $80 \%$ a redução da mortalidade por CC decorrente do uso deste exame (Ault, 2011). No entanto, o teste citológico convencional é bastante trabalhoso, e apresenta várias limitações: baixa a moderada sensibilidade (o que requer a realização de exames frequentes, especialmente no início), baixa reprodutibilidade, e grande dependência de treinamento e controle de qualidade (Koss, 1989; Longatto-Filho \& Schmitt, 2010). Avanços nos métodos moleculares e no conhecimento da história natural da doença culminaram em novas tecnologias para o rastreio, cujo alvo é o material genético do papilomavírus humano (HPV), especificamente dos tipos de alto risco, que são os agentes causais do CC. São técnicas automatizadas, compatíveis com grandes rotinas como é o caso do rastreio populacional. A maior sensibilidade dos testes moleculares de detecção do DNA HPV 
em relação ao teste convencional é amplamente reconhecida (Schiffman, et al., 2011; Arbyn et al., 2009).

Um algoritmo mais racional derivado desses estudos (Rijkaart et al., 2012; Dijkstra et al., 2014; Ronco et al., 2014; Tota et al., 2014) sugere o emprego do teste molecular no rastreio primário, e a citologia, por sua maior especificidade, restrita às amostras HPV-DNA positivas, em que esses HPVs são do grupo denominado de alto risco (HrHPV) para câncer. Nesse sentido, a citologia de base líquida (LBC), além de representar a evolução técnica da citologia convencional, oferece um único meio de coleta, que preserva os ácidos nucleicos e permite o transporte e armazenamento das amostras à temperatura ambiente, perfeitamente compatível com este algoritmo.

Várias projeções e modelos sugerem ainda que a substituição do rastreio primário citológico pelo molecular é custo-efetivo. Embora este tipo de análise seja absolutamente específico para cada país e realidade de seu sistema de saúde, o rastreio molecular mostrou-se custo-efetivo em cenários tão distintos como a África do Sul (Vijayaraghavan et al., 2009) e a Holanda (van Rosmalen, de Kok, van Balleggijen, 2012).

No entanto, cabe ressaltar que tais iniciativas não são consensuais. As diretrizes da US Preventive Services Task Force para rastreio do câncer cervical não recomendam o rastreio primário com teste de HrHPV, porém recomendam o co-teste HrHPV + citologia para mulheres entre 30 e 65 anos de idade, como uma opção para aumentar o intervalo de rastreio de 3 para 5 anos (Moyer, 2012).

Há cerca de uma década acumulam-se fortes evidências de que o teste de Papanicolaou coletado em meio líquido (citologia de base líquida, do inglês Liquid Base Citology) tem sensibilidade e especificidade semelhantes às da citologia convencional (Siebers et al., 2009). A citologia líquida proporciona preparados homogêneos e limpos 
e de campos reduzidos e bem delimitados, que facilitam a leitura e possibilitam melhor desempenho dos citotécnicos e citologistas reduzindo significativamente a proporção de esfregaços insatisfatórios (Ronco et al., 2007), além de permitir a leitura por sistema automatizado (Wilbur et al., 2009). Esses meios líquidos trazem ainda valores agregados que rentabilizam sua utilização, ao fornecerem meios adequados para se preservar idealmente DNA, RNA e proteínas. Com isso, os testes que identificam os HrHPVs são facilmente realizados em LBC da mesma amostra colhida para o teste de Papanicolaou (Monsonego et al., 2012). Os testes moleculares para identificação de HrHPVs são significativamente mais sensíveis que a citologia para identificação de lesões associadas à infecção do HPV, principalmente HSIL+ (Ronco et al., 2014). Embora o teste, a priori, identifique infecção e não lesão (por isso mesmo ele é menos específico que a citologia), o rastreamento primário com teste de DNA de HrHPVs, seguido do Papanicolaou em mulheres HrHPV positivas, possibilita não só maior detecção de lesões de alto grau (HSIL+), como também maior especificidade do que a estratégia tradicional com somente citologia (Franco, 2009). Esses dados apontam para uma substituição do teste de Papanicolaou como primeira opção no rastreio primário, reservando a citologia para atuar como teste reflexo ao teste molecular (Longatto-Filho \& Schmitt, 2007), ou ainda para utilização de ambos os testes combinados (Saslow et al., 2012).

Um desafio ao uso de teste molecular para HrHPV no rastreio é a alta prevalência de HPV na população em geral, especialmente na faixa etária abaixo dos 30 anos (Bruni et al., 2010). Neste grupo, o teste molecular tem baixa especificidade, e levaria a uma taxa elevada de colposcopias, podendo inclusive interferir na futura saúde reprodutiva, por intervenções terapêuticas em sua maioria desnecessárias, uma vez que a maioria das infecções e lesões por HPV regridem espontaneamente nesta faixa etária 
(Castle et al., 2005). Em alguns países desenvolvidos que estão utilizando o algoritmo de rastreio com teste molecular para HrHPV, evita-se esta perda de especificidade adotando-se a política de início do rastreio após os 29 anos (Rijkkart et al., 2012). Esta estratégia está em desacordo com a diretriz oficial no Brasil, de início de rastreio aos 25 anos (MS-Inca, 2016). Por outro lado, dados do Registro Hospitalar de Câncer da FOSP mostram que a proporção de mulheres com menos de 30 anos com câncer cervical invasivo é pequena. Entre janeiro de 2000 e abril de 2012 foram contabilizados no Estado de São Paulo 13.760 casos de câncer cervical invasivo, dos quais 436 (3,2\%) ocorreram em mulheres entre 25 e 29 anos de idade e $122(0,9 \%)$ em mulheres entre 20 e 24 anos. O último boletim do Inca indica que cerca de $15 \%$ dos exames citopatológicos em São Paulo provém desta faixa etária (Inca, 2012). Neste estudo não foi impedida a entrada de mulheres com menos de 25 anos, no entanto, o algoritmo proposto para esta população seguiu uma conduta mais conservadora para aquelas com resultado isolado de HrHPV positivo.

A forma mais prática de se obter uma conjugação eficaz de citologia e teste molecular é através da realização da citologia reflexa para todas as mulheres com resultado HrHPV+, encaminhando-se à colposcopia apenas aquelas com alteração citológica. Outra sugestão é a repetição do teste molecular após 1 ano, e aquelas repetidamente positivas para HPV de alto risco sejam então referidas à colposcopia. Estes algoritmos podem ser ainda mais complexos pelo uso de fluxos diferentes de acordo com a idade da paciente, sempre sob a lógica do menor valor preditivo do resultado HrHPV+ nas mais jovens.

Outra estratégia de estratificação de risco que vem sendo sugerida na literatura é baseada na genotipagem do HPV de alto risco (Castle et al., 2011a). Esta estratégia decorre do reconhecimento da distinta capacidade oncogênica entre os HPVs de alto 
risco para câncer. Estudos com diferentes desenhos epidemiológicos mostraram que os HPVs 16 e 18 apresentam maiores riscos de desenvolvimento de doença (Khan et al., 2005; Stoler et al., 2012) e taxas de evolução de infecção para neoplasia intraepitelial cervical (NIC) e CC mais rápida que os outros HrHPVs não-16 e 18 (de San José et al., 2010). No entanto, outros genótipos de HrHPV podem ter uma oncogenicidade semelhante à do HPV 16 em populações específicas, como o HPV 58 em Taiwan (Chen et al., 2011). A maioria dos estudos realizados no Brasil identificou uma distribuição genotípica de HPV semelhante aos EUA e Europa Ocidental, com maior preponderância dos HPVs 16 e 18 nos CC (Rabelo-Santos et al., 2003). Dados do Instituto Nacional de Ciência e Tecnologia dos Papilomavírus Humano (INCT-HPV) revelaram uma frequência importante do HPV 56 em casos de NIC 2+ (Levi et al., 2014).

Este estudo visa avaliar o desempenho de novo teste molecular de HrHPV e LBC na elaboração de um novo algoritmo para implantação no programa de detecção de câncer de colo do útero no Estado de São Paulo. 
2. Revisão da Literatura 


\subsection{HPV um breve histórico}

Até o final da década de 1970 os Papilomavírus (PVs) eram conhecidos apenas como agentes causais de "verrugas" lesões benignas cutâneas em alguns mamíferos e seres humanos (Bernard et al., 2005). As verrugas genitais, também conhecidas como condilomas, são descritas desde a antiguidade (Clarck et al., 1965). Registros da Grécia antiga já faziam referência às lesões verrugosas ou papilomatosas em algumas regiões corporais, como as áreas genitais, palmares e plantares, sendo denominadas de Ficus, Thymus, Thimion ou Condyloma acuminatum. A primeira evidência da etiologia viral foi reportada na Itália no início do século XX (Ciuffo, 1907). No entanto, a demonstração da presença de partícula viral, por microscopia eletrônica, ocorreu apenas em 1949 (Strauss et al., 1949).

Após inúmeras pesquisas, Harald zur Hausen no final da década de 1970 sugeriu a associação entre o Papilomavírus Humano (HPV) e o câncer cervical ampliando o interesse por este vírus (zur Hausen, 1976). Por meio de métodos de biologia molecular foi demonstrado de forma indubitável a correlação do HPV e câncer cervical, motivo este que lhe conferiu o Prêmio Nobel de Medicina em 2008.

\subsubsection{Classificação, Biologia e Nomenclatura dos HPVs}

Os Papilomavírus (PVs) pertencem a um grupo de vírus encontrados em mais de 20 espécies de mamíferos, além de aves e répteis, sendo os Papilomavírus Humanos (HPVs) os mais estudados (de Villiers et al., 2004; Doorbar, 2005). 
Os HPVs são um grupo de vírus pequenos sem envelope, com o genoma de DNA de cadeia dupla circular com aproximadamente 8.000 pares de bases (pb). São exclusivamente epiteliotrópicos, sendo associados com diversas manifestações clínicas cutâneas ou mucosas que variam de desordens proliferativas benignas para câncer do trato genital, pele, orofaringe, laringe e esôfago (Castellsagué 2008; Schiffman et al., 2016).

O DNA circular pode ser dividido em três segmentos, Figura 1:

1. Região precoce: estes vírus apresentam seis genes precoces "E" (do inglês early) que codificam as proteínas não estruturais (E1, E2, E4, E5, E6 e E7) envolvidas na replicação viral e transformação;

2. Região tardia: dois genes tardios "L" (do inglês late) responsável pela síntese das proteínas do capsídeo L1 e L2;

3. Região regulatória "LCR" (do inglês long control region): região não codificante, contém a origem da replicação do DNA e elementos do controle da transcrição (Ferhmann e Laimins, 2003).

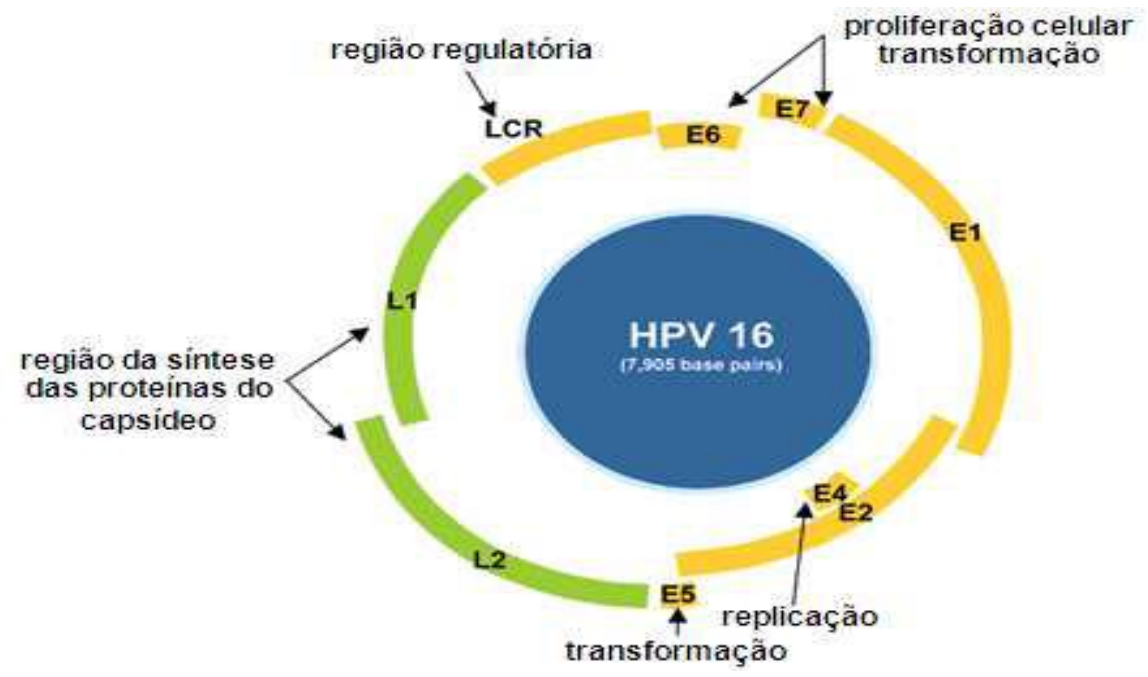

Figura 1- Representação esquemática do genoma do HPV (Adaptado de Villa, 2006) 
De acordo com o International Committee on the Taxonomy of Viruses (ICTV), o HPV é membro da família Papillomaviridae, gêneros papilomavírus Alfa, Beta, Gama, Delta, Kappa, Lambda, Um, Nu e Zeta entre outros. A Figura 2, apresenta os HPVs divididos em cinco grupos diferentes de acordo com o tropismo epitelial e associação à doença. Nos humanos, os HPVs podem ser divididos clinicamente em três grupos: - Gênero Alfapapillomavirus: considerados os clinicamente mais importantes por estarem associados a etiologia do câncer cervical e suas lesões precursoras, Betapapilomavírus: associados a lesões cutâneas, existem na forma latente na população, quando ativados estão associados a epidermodisplasia verruciforme, uma doença rara de base hereditária; e os Gamapapilomavírus: associados a verrugas cutâneas (de Villiers et al., 2004; Poljak et al., 2016).

A Agência Internacional para Pesquisa sobre o Câncer (IARC) classificou 12 tipos de HPVs como oncogênicos ou de alto risco por estarem associados com lesões intraepiteliais escamosas de alto grau (HSIL) ou câncer cervical, tipos: 16, 31, 33, 35, 52 e 58 (Alfa-9), 18, 39, 45 e 59 (Alfa-7), 51 (Alfa-5), 56 (Alfa-6), em que se destacam os HPVs 16 e 18, responsáveis por cerca de $70 \%$ do total de casos deste tipo de câncer. Os tipos 53, 66 e 68 entre outros são provavelmente carcinogênicos, enquanto os tipos 6,11, 40, 42, 43, 44 e 55 estão associados ao baixo risco de lesões e comumente relacionados aos condilomas acuminados, condilomas planos ou lesões intraepiteliais de baixo grau (LSIL), conhecidas como neoplasias intraepiteliais cervicais grau 1 (Iarc, 2014; Schiffman et al., 2016)

A classificação está baseada na análise das sequências de nucleotídeos do gene L1, altamente conservado no vírus. Um novo tipo é descrito quando as variações de nucleotídeos são superiores a 10\%, variações entre 2 e $10 \%$ determinam subtipos de 
HPV e recebem um número sequencial à medida que diferentes tipos são descobertos (de Villiers et al., 2004).

Dos mais de 200 tipos de HPVs identificados, aproximadamente 40 podem infectar o colo do útero. A variação do potencial oncogênico desses tipos de HPVs está relacionada em parte com a expressão de dois genes precoces, E6 e E7. Os HPVs infectam queratinócitos na camada basal do epitélio que fica exposta por microfissuras, como representado na Figura 3 (Frazer, 2004). Na infecção, os genomas virais permanecem no núcleo na forma epissomal com baixo número de cópias e os genes precoces virais são expressos. Após a divisão celular, ocorre a migração de uma célula filha da camada basal e ocorre a diferenciação celular. É nas células diferenciadas que ocorre a replicação dos genomas virais, o que caracteriza a fase produtiva do ciclo celular viral e que depende de síntese de DNA celular. A expressão das proteínas precoces E6 e E7 mantém as células diferenciadas do epitélio em fase S, desta forma permitindo a amplificação do genoma viral. Os genomas virais recém-sintetizados são encapsulados pelas proteínas da fase tardia L1 e L2 e então os vírions liberados das camadas externas do epitélio (Moody e Laimins, 2010). O potencial oncogênico dos HPVs está relacionado principalmente aos genes precoces, E2, E6 e E7, sendo que o primeiro é responsável pela regulação da transcricão dos outros dois. O mecanismo de indução à carcinogênese mediada pela infecção persistente por tipos oncogênicos do HPV é o resultado da ação conjunta das proteínas virais E6, E7 principais proteínas virais transformantes e E5 que aumenta a proliferação celular, podendo contribuir com a progressão do câncer (Moody e Laimins, 2010).

Nas lesões contendo o HPV na forma epissomal a proteína E2 funciona como reguladora positiva ou repressora da síntese das proteínas da fase precoce do ciclo viral, incluindo as oncoproteínas E6 e E7. A literatura descreve que um passo fundamental 
para a carcinogênese seria a integração do genoma viral ao genoma do hospedeiro. Neste processo, o HPV sofreria uma deleção no gene E2, tornando-o inativo, o que determina aumento da transcrição dos genes E6 e E7, acelerando o processo de transformação e imortalização celular, o que resulta em danos ao DNA. As proteínas E6 e E7 dos principais tipos de HPVs oncogênicos formam complexos com proteínas celulares envolvidas no controle do ciclo celular, supressoras de tumor, a p53 e a pRb inativando as suas funções como controladoras do mesmo, tendo como conseqüência uma maior atividade proliferativa e mitótica celular, e a expressão contínua destas proteínas na célula provoca inúmeros efeitos abolindo muitos pontos de checagem do ciclo celular que resultam na imortalização e transformação maligna da célula (Schiffman, 2011; Mclauglin-Drubin et al., 2013). No entanto, há estudos que detectaram somente cópias epissomais em tumores cervicais, o que indica outros fatores podem influenciar no mecanismo de carcinogênese, o que gera controvérsia sobre se a integração viral seria de fato pré requisito fundamental para a transformação maligna (Cheung et al., 2013). 


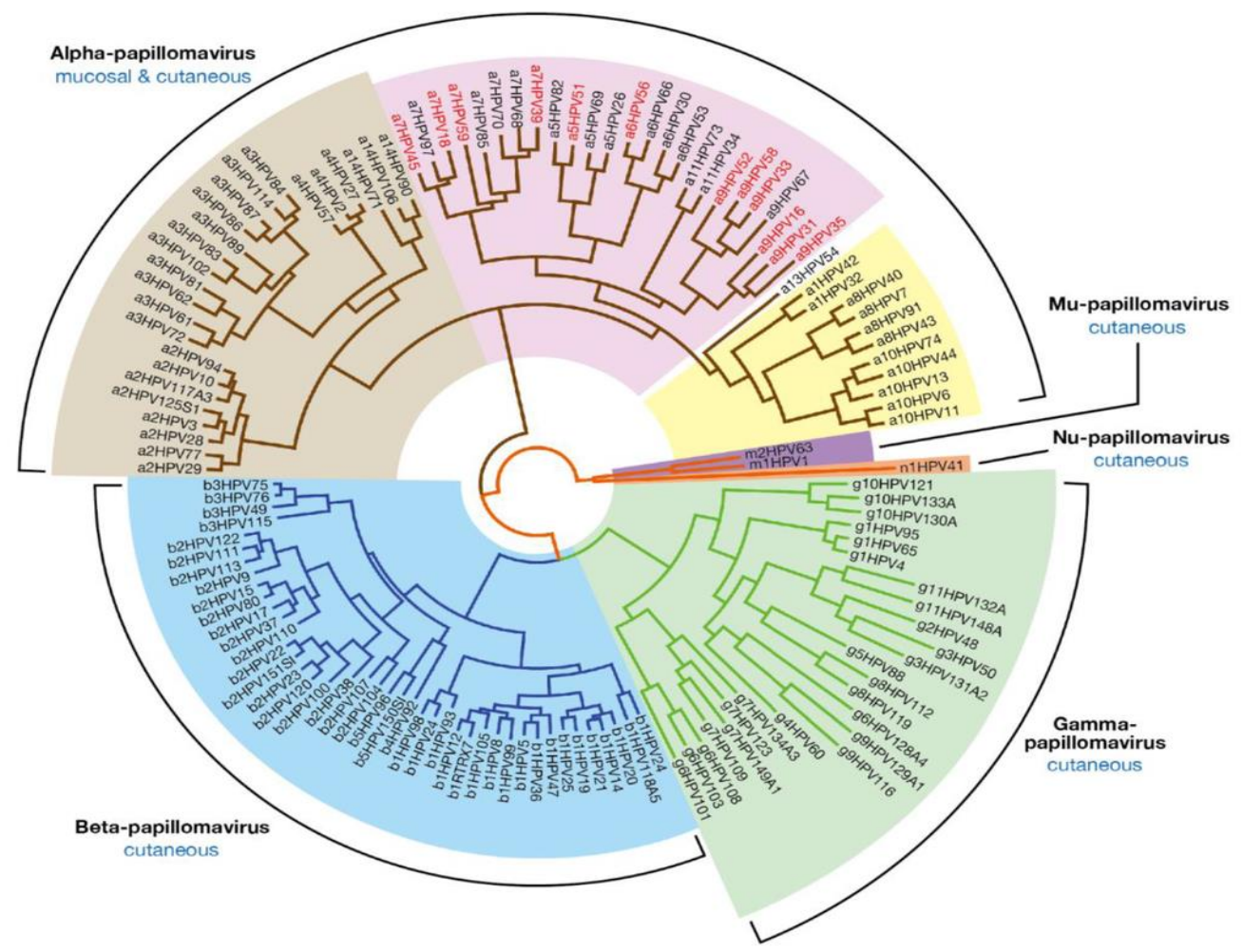

Figura 2- Esquema representativo dos gêneros do HPV e seus tipos. (Doorbar et al., 2015).

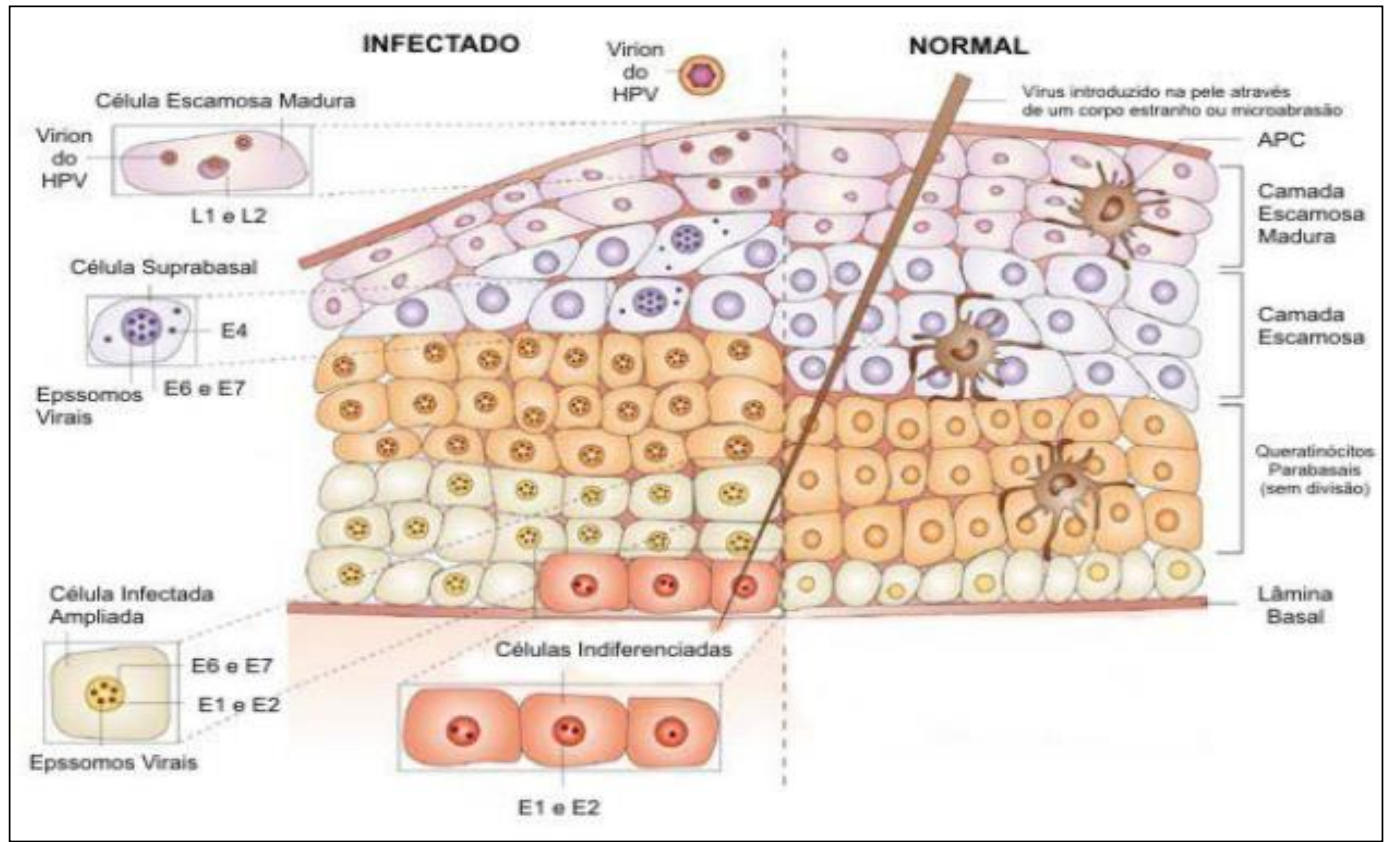

Figura 3- Ilustração do ciclo celular da infecção e principais etapas do ciclo do HPV (adaptado de Frazer, 2004). 


\subsection{Epidemiologia do câncer cervical}

O câncer de colo do útero é considerado um problema de saúde pública devido a sua elevada incidência e alta taxa de mortalidade. As estimativas mundiais sobre incidência e mortalidade por este câncer são de 527.624 casos/ano e 265.623 óbitos/ano, com a incidência maior em países em desenvolvimento. Representa a quarta causa de câncer mais comum entre as mulheres, e quando estratificado por faixa etária é o segundo mais frequente em mulheres com idade entre 15 e 44 anos (Who, 2014).

A infecção persistente por HPVs de alto risco desempenha um papel importante na etiologia desta neoplasia, o elevado índice de doença causada por HPV é um problema de saúde pública global. A Organização Mundial da Saúde (OMS) estima que haja no mundo cerca de 440 milhões de indivíduos com a infecção genital pelo HPV e que aproximadamente $10 \%$ de todas as mulheres estão infectadas por algum tipo de HPV (de Sanjosé et al., 2007).

A incidência é variável por região geográfica, as estimativas para o ano de 2012 mostraram que as maiores taxas de incidência por este tipo de neoplasia são observadas no continente africano (27,6/100.000 hab), com destaque para as regiões Leste (43/100.000 hab) e Sul (31,5/100.000 hab); na América Central (23,5/100.000 hab), na América do Sul (20/100.000 hab); no Sul da Ásia (19,3/100.000 hab), e as mais baixas (menor de 15 por 100.000 hab) ocorrem no Oeste Asiático (4,4/100.000 hab); na Oceania (Austrália e Nova Zelândia; 5,5/100.00 hab); América do Norte (6,6/100.00 hab) e Oeste Europeu (7,3/100.00 hab) (Who, 2014).

No Brasil, o câncer de colo do útero é o terceiro mais comum, precedido apenas pelo câncer de pele do tipo não-melanoma e pelo câncer de mama (Inca, 2016). Entre os anos de 1979 e 2000, houve um aumento de 33,1\% na mortalidade por câncer 
cervical (Rosemblatt et al., 2005). Este tipo de câncer é o mais incidente na região Norte (24/100.000 hab) desconsiderando-se os tumores de pele não melanoma, nas regiões Centro-Oeste (20,7/100.000 hab) e Nordeste (19,5/100.000 hab) ocupa a segunda posição, e nas regiões Sudeste (11,3/100.000 hab) e Sul (15,2/100.000 hab) ocupam a terceira e quarta posição respectivamente. No estado de São Paulo a estimativa para o ano de 2016 foi de 2.120 novos casos (9,5/100.000 hab), e na capital 720 casos novos (11,6/100.000 hab), em contraste com o Estado do Amazonas com uma taxa de 37,1 casos por 100.000 mulheres e a capital Manaus com 53,7 casos para cada 100.000 habitantes. A Figura 4 demonstra as taxas brutas de incidência de câncer de colo do útero por 100 mil habitantes estimadas para o ano de 2016, segundo Unidade da Federação (IncA, 2016).

Contudo, este é um tipo de câncer que pode ser evitado com o auxílio do diagnóstico precoce e do desenvolvimento de ações básicas organizadas de prevenção e políticas de proteção à saúde da mulher (Inca, 2016).

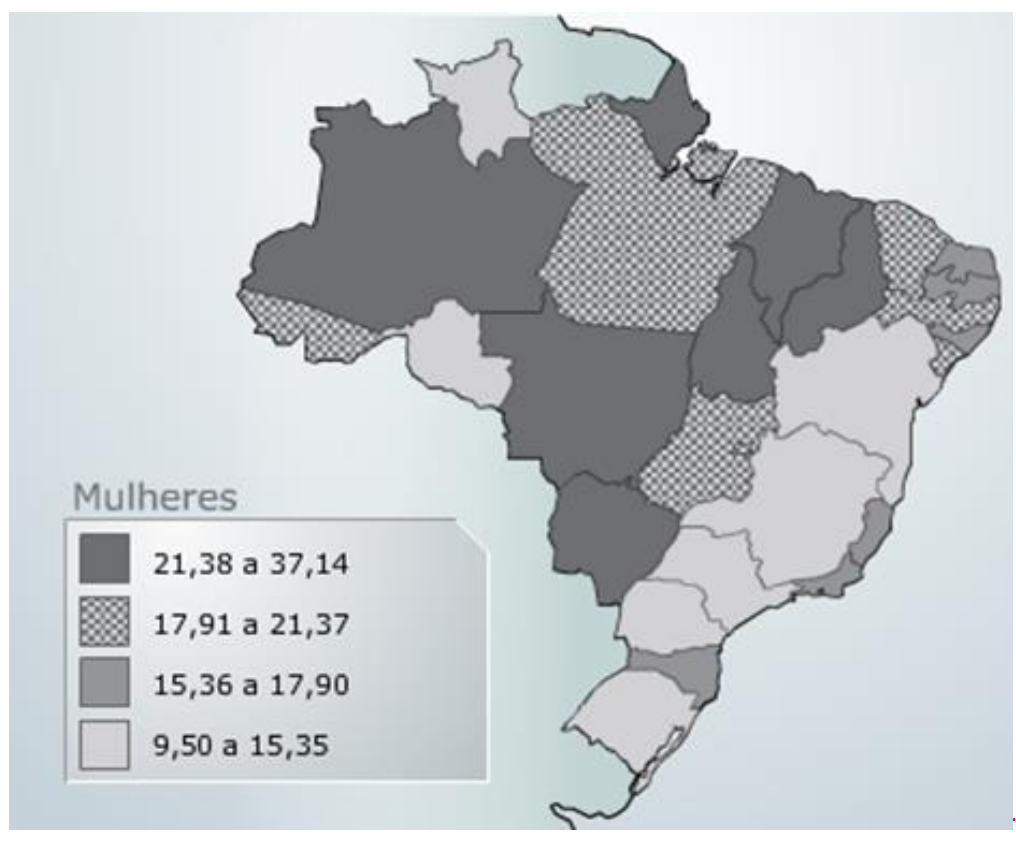

Figura 4- Representação das taxas brutas de incidência de câncer do colo do útero por 100 mil mulheres, estimadas para o ano de 2016 segundo Unidade da Federação (Inca, 2016). 


\subsection{História natural das infecções pelo hpv, câncer cervical e suas lesões precursoras}

A infecção pelo HPV acomete homens e mulheres, a transmissão do vírus se dá por contato direto com a pele ou mucosa infectada, sendo a via sexual a principal forma de transmissão que inclui contato oral-genital, genital-genital ou mesmo manual-genital (Inca, 2016). Apresenta prevalência em torno de $5 \%$ a $20 \%$ na população geral e de $20 \%$ a $40 \%$ entre as mulheres jovens (Santos et al, 2003, Thomisson, Thomas, Shroyer, 2008; Who, 2014).

Uma prevalência maior da infecção pelo HPV tem sido observada em mulheres com menos de 34 anos, diminuindo no grupo dos 35 a 44 anos e aumentando na faixa etária dos 45 aos 54 anos, com exceção em países da Ásia, onde a prevalência continua decrescendo nesse grupo etário (de Sanjosé et al., 2007). Na maioria dos indivíduos a infecção é assintomática e transitória; 70\% dos casos novos regridem em até um ano, e do restante, cerca de 90\% em dois anos (Steben \& Franco, 2007; OÑA et al., 2010).

Além da atividade sexual ser a maior causa, as mulheres adolescentes e jovens são mais propensas a infecção pelo HPV também por razões biológicas. Os estudos histológicos e colposcópicos mostram que a maioria das transformações epiteliais iniciais do colo desenvolve-se na zona de junção dos epitélios escamoso e cilíndrico, denominada zona de transformação. Na puberdade, o epitélio colunar transforma-se gradualmente em epitélio escamoso, processo denominado de metaplasia escamosa. Durante este processo, grandes áreas escamosas, glandulares e metaplásicas de transição são formadas e favorecem a infecção pelo HPV. Nesse período, não somente as células do colo uterino estão em proliferação, como favorecem a replicação do HPV e tornamse susceptíveis ao desenvolvimento de alterações induzidas pelo vírus e, se a infecção 
persistir, podem levar a progressão para lesões intraepiteliais escamosas de alto grau HSIL (Gompel \& Koss, 1997; Moscicki, 2005).

Estudos longitudinais com grande número de mulheres acompanhadas demonstraram que a persistência de HPV de alto risco confere uma chance significativa de desenvolvimento de lesões precursoras (Schiffman et al, 1993). Kjaer e colaboradores (2002), estudando mulheres com citologias normais demonstraram que a incidência de lesões intraepiteliais de alto grau (HSIL) foi 28,4 vezes maior nas mulheres que apresentaram persistência por HPV de alto risco quando comparadas as mulheres que tiveram clareamento da infecção (Kjaer et al., 2002). A persistência e a progressão das infecções pelo HPV variam de acordo com o genótipo do vírus, mesmo entre os HPVs de alto risco oncogênico (Matsumoto et al., 2011). Os tipos de HPV que mais contribuem para o câncer cervical são: HPV-16, 18, 58, 33, 45, 31, 52, 35, 59, 39, 51 e 56 (Li et al., 2011).

No Brasil, estudo realizado Schlecht e colaboradores (2003) demonstrou que na presença de HPVs de alto risco, o tempo médio de progressão de uma amostra com atipia escamosa de significado indeterminado (ASC-US) para uma lesão intraepitelial escamosa de baixo grau (LSIL) ou maior precede em 21 meses (67 vs 88) em relação às mulheres HPV negativas. Uma progressão em menor intervalo também foi observada nos casos de LSIL para uma lesão intraepitelial escamosa de alto grau (HSIL), 10,2 meses $(73,3$ vs 83,5$)$ quando associadas a presença de genótipos oncogênicos (Schlecht et al., 2003).

A estratificação de risco adicional pelo tipo de HrHPV pode ser usada na formulação de decisões do manejo clínico das pacientes. A detecção de HPVs de alto risco, particularmente dos tipos 16 e 18, é capaz de identificar lesões com maior 
propensão à progressão, ou que progredirão de forma mais rápida (Castle et al., 2011a; Stoler et al., 2012). O resultado negativo, ou a detecção de outros tipos de HPV diferentes de 16 e 18, identifica indivíduos com menor risco de desenvolver neoplasia, que poderão ser seguidos em intervalos mais espaçados, com redução de custos e de procedimentos desnecessários (Schiffman et al, 2011).

\subsection{Vacinação}

A prevenção primária por vacinação profilática é a intervenção mais eficaz a longo prazo para o controle de infecções por HPV de alto risco e em última análise do câncer cervical (Stanley et al, 2012). Atualmente estão disponíveis no Brasil duas vacinas, a bivalente que protege contra os tipos virais 16 e 18, e a vacina quadrivalente que inclui também os HPVs 6 e 11, responsáveis por cerca de 90\% das verrugas genitais (Portal Brasil, 2016a). As vacinas tem como base a indução de anticorpos neutralizantes capazes de prevenir a infecção pelo HPV, para isso os antígenos utilizados baseiam-se na proteína estrutural do capsídeo viral L1, gerando uma estrutura semelhante àquela encontrada nos vírions. Estas estruturas, morfologicamente assemelhadas ao vírus, porém vazias, foram denominadas de vírus-like particles (VLPs). As VLPs são destituídas de DNA ou produtos biológicos e consideradas seguras, pois induzem forte resposta imune sem o risco de infecção ou de produzir uma neoplasia. (Schiller et al., 2008).

No Brasil, desde junho de 2013 o Ministério da Saúde anunciou a decisão de introduzir a vacina quadrivalente a qual confere proteção contra os HPVs 6, 11, 16 e 18. O modelo adotado pelo Programa Nacional de Imunização (PNI) é baseado em duas 
doses (0 e 6 meses). Em 2014 esta vacina passou a ser oferecida para as meninas na faixa etária de 11 a 13 anos, e a partir de 2015 para meninas de 9 a 11 anos (Portal Brasil, 2016a). De modo a tornar prevenção mais eficaz, a partir de janeiro de 2017 o Ministério da Saúde do Brasil passa a disponibilizar a vacina contra o HPV para meninos de 12 a 13 anos na rotina do Calendário Nacional de Vacinação do Sistema Único de Saúde (SUS). A faixa etária será ampliada, gradativamente, até 2020, quando serão incluídos os meninos com 9 anos até 13 anos (Portal Brasil, 2016b).

Recentemente, foi aprovada pelo FDA, a vacina nonavalente, a qual se apresenta como alternativa segura e efetiva na prevenção de infecções persistentes e lesões pré neoplásicas associadas aos HPVs 16/18/31/33/45/52/58 que somados são responsáveis por aproximadamente $92 \%$ dos casos de câncer cervical, além das verrugas genitais relacionadas aos tipos de HPVs 6 e 11 (Chatterjee, 2014).

\subsection{Métodos de detecção e tipagem do hpv}

\subsubsection{Diagnóstico Morfológico do HPV}

O diagnóstico morfológico das infecções pelo HPV é amplamente utilizado tanto em esfregaços celulares quanto em cortes de tecido. A presença inequívoca de coilócitos ou disqueratócitos indica uma infecção produtiva por estes vírus. Entretanto, com o desenvolvimento de técnicas de detecção do DNA viral tornou-se evidente a baixa sensibilidade do diagnóstico morfológico, que geralmente resulta em um grande número de resultados falso-negativos (Farthing et al., 1994). 


\subsubsection{Método de rastreamento: Citologia Oncótica ou Citopatologia}

A primeira forma de detecção de alterações compatíveis com a infecção pelo HPV foi a coloração pelo método de Papanicolaou, introduzida no ano de 1949, antes mesmo da causa do câncer cervical ser conhecida (Gompel \& Koss, 1997).

O diagnóstico morfológico da infecção pelo HPV, por meio de esfregaços cervicais (citologia oncótica), conhecidos popularmente como exame preventivo de Papanicolaou, é amplamente utilizado para o rastreamento de populações com a finalidade de detectar as lesões pré-neoplásicas e neoplásicas do colo uterino. Atualmente é a estratégia preventiva (rastreamento) mais utilizada na rede de atenção básica à saúde por ser indolor, de baixo custo e eficaz (Inca, 2016).

A observação de alterações celulares típicas como presença de coilócitos, disceratose, anomalias celulares compatíveis com a infecção pelo HPV é definida em graus variados. A classificação dos resultados do Papanicolaou sofreu algumas modificações desde a introdução do método, e em 2014 com os avanços tecnológicos, introdução de novas modalidades na prevenção do câncer do colo do útero foi feita uma revisão e atualização com inclusão de informações adicionais na terminologia do sistema de Bethesda a qual é utilizada mundo afora. A atual classificação separa as anormalidades das células escamosas em: - ASC (células escamosas atípicas) subdividida em ASC-US (células escamosas atípicas de significado indeterminado) e $A S C-H$ (células escamosas atípicas de significado indeterminado em que não é possível excluir uma lesão intraepitelial de alto grau); LSIL (lesão intraepitelial escamosa de baixo grau), HSIL (lesão intraepitelial escamosa de alto grau) e SCC (carcinoma de células escamosas). Entre as atipias glandulares são consideradas aquelas de significado indeterminado (AGC), o adenocarcinoma in situ e invasor (Nayar \& Wilbur, 2015). O 
Brasil utiliza sua própria nomenclatura, a Nomenclatura Brasileira para Laudos Citopatológicos e condutas preconizadas, a qual apresenta similaridades com a codificação internacional do Sistema de Bethesda 2001 (MS-Inca, 2011).

Em 1998, o Ministério da Saúde no Brasil, implantou o Programa Nacional de Controle do Câncer de Colo do Útero e de Mama denominado "Viva Mulher" que amplia a oferta do exame convencional de Papanicolaou, com o objetivo de reduzir as taxas de morbi-mortalidade por esta neoplasia. O programa prioriza mulheres de 25 a 64 anos. No entanto, muito ainda é preciso avançar para alcançar uma cobertura ampla das mulheres suscetíveis ao desenvolvimento do câncer cervical, ou seja, todas as que já iniciaram sua atividade sexual (Nanda et al, 2000; Inca 2016). A recomendação do Instituto Nacional do Câncer (Inca) é de que os dois primeiros exames devam ser feitos com um intervalo de um ano. Quando os resultados destes dois exames são normais, o rastreamento pela citologia deverá ser feito a cada três anos (Inca, 2016).

Entretanto, o teste apresenta um número elevado de resultados falso-negativos que variam em torno de $15 \%$ a $50 \%$ e percentuais de resultados falso-positivos de $10 \%$ em média (Cavalcanti \& Carestiato, 2006). A citologia oncótica não tem sensibilidade aceitável para a detecção do adenocarcinoma cervical e seus precursores (Lie \& Kristensen, 2008). Assim, um esfregaço negativo em uma paciente sintomática nunca deve ser considerado como resultado definitivo (Inca, 2016). Cerca de $40 \%$ dos casos de câncer cervical ocorrem em mulheres que recentemente receberam um resultado negativo de citologia oncótica (Altiok, 2003).

Mesmo assim, nos últimos anos, os países desenvolvidos com programas de prevenção organizados e que empregaram, como medida preventiva a citologia oncótica, diminuíram muito os casos de cânceres cervicais, como Finlândia, Suécia, Dinamarca e Islândia os quais apresentaram uma queda de 50\% na incidência do câncer 
cervical após a implantação no início dos anos 60, como também nos Estados Unidos da América na mesma década com redução em $75 \%$ dos casos deste tipo de câncer. Nas Américas Central e do Sul, a cobertura dos programas pode ser alta, mas a qualidade dos programas de citologia e o acesso ao tratamento são insuficientes e por esses motivos as taxas de câncer cervical permanecem das mais altas documentadas no mundo (Kitchener et al.,2006; Monsonego et al., 2011).

\subsubsection{Citologia em base Líquida (LBC)}

A última década testemunhou várias mudanças no rastreio, prevenção e gestão do câncer cervical. Entre elas, o aumento do uso de preparados citológicos a base de meio líquidos, automação e imagem assistida por computador que gradativamente vem tendo o uso incorporado por laboratórios especializados (Nayar \& Wilbur, 2015).

A citologia em base líquida surgiu para atender as demandas de escrutínio computadorizado. Para que a leitura das lâminas por computadores fosse viável, era necessário um preparado com o menor número possível de artefatos e sobreposições celulares (Mcgoogan et al., 1998). Esta metodologia é o resultado de mais de uma década de pesquisas, na busca de um único meio, com condições de preparo citológico de excelência em fixação, preservação celular e também adequado para estudo molecular (Velasco, 2001). Existem diferentes sistemas de preparo de citologia em meio líquido, entre eles o Surepath (BD SurePath TM - TriPath, Burlington, NC, EUA.) e Thin Prep® (Hologic, Inc., Bedford, MA). Desde a década de 1990, o FDA (Federal Drug Administration - EUA) aprova e recomenda a metodologia de base líquida como alternativa ao exame de Papanicolaou convencional no rastreamento do câncer cervical (Ferenczy e Franco, 2001; Monsonego, 2006). 
A LBC permite melhor avaliação e performance dos citologistas, reduzindo significantemente a proporção de amostras insatisfatórias, redução de elementos que dificultam o diagnóstico, como presença de muco, sangue e células inflamatórias (Longatto-Filho \& Schmitt, 2007). De forma adicional, a LBC além de representar o desenvolvimento técnico do preparado convencional, também oferece um único meio de coleta de amostras que preserva os ácidos nucleicos, permite o transporte $\mathrm{e}$ armazenamento das amostras à temperatura ambiente e triagem em algoritmos que incluem o teste de HPV (Longatto-Filho \& Schmitt, 2010; Schmitt et al., 2008). Uma série de publicações recentes demonstraram claramente que LBC oferece maior índice de positividade citológica, e redução persistente e notável de preparações insatisfatórias (Arbyn et al., 2008; Scapulatempo et al., 2013).

\subsubsection{Histopatologia}

O exame histopatológico do colo do útero é aceito como procedimento definitivo (padrão-ouro) para o diagnóstico de lesões precursoras e neoplásicas do colo do útero (Iarc, 2016). É um procedimento de grande importância, e é nele que se baseia a maioria das decisões terapêuticas até o momento. Além de auxiliar no diagnóstico da infecção pelo HPV, o estudo histopatológico é capaz de graduar as lesões de acordo com seu potencial proliferativo (Souza, Melo \& Castro, 2001).

A classificação histopatológica de (Richart 1967) é adotada por grande parte dos laboratórios, utiliza a coloração hematoxilina-eosina e divide as lesões intraepiteliais em três graus: a proliferação celular anormal ocupando o terço inferior do 
epitélio é classificada como NIC 1; ocupando dois terços do epitélio, NIC 2; e ocupando todo o epitélio, NIC 3 (Richart, 1967).

Em março de 2012, o Colégio Americano de Patologistas e a Sociedade Americana de Colposcopia e Patologia Cervical, em colaboração com 35 organizações, convocou uma conferência chamada Lower Anogenital Squamous Terminology (LAST) Project. As recomendações deste projeto incluem o uso de uma terminologia uniforme para descrever a histologia de doenças humanas associadas ao papilomavírus em todos os tecidos do trato anogenital: vulva, vagina, colo do útero, pênis e ânus. A terminologia recomendada é de "baixo grau" ou "alto grau" de lesão intraepitelial escamosa (SIL), a qual é familiar para os médicos por se assemelhar a terminologia dos relatórios citológicos do sistema de Bethesda. Os resultados de biópsia utilizando terminologia SIL podem ainda ser mais qualificados ao utilizar-se a nomenclatura "neoplasia intraepitelial" (NIC) entre parênteses, por exemplo: HSIL ou HSIL (NIC 2) e também HSIL (NIC 3) (Waxman et al., 2012).

A infecção pelo HPV promove a replicação desregulada do genoma do hospedeiro e, desta forma, proteínas envolvidas no controle do ciclo celular tem seus níveis aumentados ou diminuídos. Uma extensa revisão da literatura apontou para o uso do biomarcador p16INK4a para coloração imuno-histoquímica (p16) (Mc LaughlinDrubin et al., 2011; von Knebel Doeberitz et al., 2012). Estudos recentes mostram que a adição de imunocoloração de p16 aumenta significativamente a fidelidade do diagnóstico de NIC de alto grau, quando comparada à avaliação morfológica com hematoxilina-eosina isolada, especialmente quando p16 é utilizado como um adjuvante para o diagnóstico de NIC 2, sendo também recomendado para a diferenciação dos casos benignos que mimetizam lesões intraepiteliais de alto grau (Bergeron et al., 2015a). 
O aumento na expressão de p16 ocorre em células escamosas quando reguladores do ciclo celular, como a proteína do retinoblastoma (pRb), é inativada pela oncoproteína E7 de HPV de alto risco, mecanismo que ajuda a conduzir a transformação celular neoplásica mediada pelo HPV. A utilização destes marcadores complementa o resultado de outros exames de triagem na identificação de lesões com maior risco de progressão maligna (von Knebel-Doeberitz \& Syrjanen, 2006).

\subsubsection{Colposcopia}

A colposcopia é um exame visual especializado do colo uterino, da vagina, e da vulva (parte externa da vagina). (Hinselmann, 1925) foi o primeiro a descrever o equipamento colposcópico básico e estabeleceu os fundamentos para a prática da colposcopia (Iarc, 2014).

O colposcópio tem uma lente que amplia de 4 a 40 vezes o epitélio, no qual se aplica uma solução de ácido acético com concentração entre 3\% e 5\%, e onde houver anormalidades histológicas o epitélio torna-se esbranquiçado (acetobranco) devido a precipitação de proteínas. A vascularização também pode ser observada com o auxílio de uma luz com filtro verde. Durante o exame amostras das regiões suspeitas podem ser coletadas e biopsiadas. É um exame de extremo valor para a detecção das lesões causadas pelos HPV, entretanto, outras situações como, por exemplo, inflamações intensas, mosaicismo, também expressam um epitélio branco. Logo, existe um risco de se diagnosticar uma alteração epitelial que não é causada pelo HPV (Cavalcanti \& Carestiato, 2006). 


\subsubsection{Diagnóstico molecular do HPV}

Como resultado do conhecimento acumulado ao longo das últimas três décadas da relação causal entre a infecção pelo HPV e câncer cervical, o avanço considerável nas metodologias capazes de detectar e identificar HPVs presentes nos mais diversos espécimes biológicos, os especialistas vislumbraram a possibilidade de utilização do HPV como alvo de detecção das lesões cervicais para identificar mulheres em risco de desenvolver o câncer cervical (Cuzick et al., 2008a).

O diagnóstico molecular do HPV começou a ser utilizado na década de 1980, quando as sondas de ácidos nucléicos foram disponibilizadas comercialmente (Walboomers et al., 1999; Hubbard, 2003). A utilização de métodos mais acurados para a detecção do HPV em investigações epidemiológicas permitiu a confirmação da importância do vírus, principalmente dos tipos oncogênicos, como fator principal de risco para o desenvolvimento das neoplasias intraepiteliais e do câncer cervical (Walboomers et al., 1999).

São métodos que se baseiam na detecção de DNA ou RNA virais por técnicas de biologia molecular, apresentam elevada sensibilidade e moderada especificidade. Resultados de recentes estudos em diversos países com milhares de mulheres, tem demonstrado o grande potencial da biologia molecular como ferramenta de diagnóstico (Schiffman et al., 2011).

A diversidade dos genótipos e a incidência de infecções múltiplas tornaram necessário o estabelecimento de métodos confiáveis para identificação dos vários tipos virais, não somente para estudos epidemiológicos como também para o acompanhamento de pacientes. Devido a sua versatilidade e altíssima sensibilidade, vários sistemas baseados em PCR encontram-se disponíveis e serão mostrados adiante. 
Entre os métodos utilizados para a detecção do material genético do HPV encontram-se: a hibridização molecular com sondas de ácidos nucleicos (Southern blot, dot blot, hibridização in situ [ISH], a amplificação de sinal como a Captura Híbrida II (HC2); a Reação em Cadeia da Polimerase (PCR); e o NASBA (Nucleic Acid Sequence Based Amplification) que detecta o RNAm viral das proteínas oncogênicas E6 e E7 (Hubbard, 2003; Fuessel Haws et al., 2004; Molijn et al., 2005; Villa \& Denny, 2006; Jeantet et al., 2009).

Atualmente, os testes moleculares tem seu uso bem estabelecido em diferentes contextos clínicos, tais como: rastreio primário (Ferreccio et al., 2013); a triagem de pacientes com citologia mostrando células escamosas atípicas de significado indeterminado (ASC-US) (Stoler et al., 2007); seguimento clínico após o tratamento, o acompanhamento de pacientes com alterações citológicas sem lesões ou apenas lesões menores que foram identificadas pela colposcopia; e a resolução de resultados discordantes da citologia, colposcopia, ou achados histológicos (Schiffman et al., 2011).

\subsubsection{Teste de Amplificação de sinal - Captura de Híbridos}

O teste de Captura Híbrida (HC2, Qiagen $\left.{ }^{\circledR}\right)$, aprovado e reconhecido pela ANVISA e pelo FDA dos EUA é muito semelhante aos imunoensaios do tipo ELISA. Foi o primeiro teste a chegar ao mercado, e é muito utilizado em todo o mundo, sendo utilizado também para identificação de outros patógenos como Chlamydia Trachomatis, Neisseria gonorrhoeae e Herpes vírus. Em relação ao HPV, este método não identifica o tipo viral, e sim os grupos virais, baixo e alto risco. É baseado na reação de hibridização, que utiliza sondas sintéticas de RNA, não radioativas, complementares às 
sequências genômicas de 18 tipos de HPVs que comumente infectam o trato anogenital, sendo 13 tipos de HPVs de alto risco $(16,18,31,33,35,39,45,51,52,56,58,59$ e 68) e cinco tipos de baixo risco (6, 11, 42, 43 e 44) (Molijn et al., 2005; Tsiodras et al., 2010).

Os híbridos formados são capturados por anticorpos anti-híbridos RNA:DNA presentes no revestimento das placas utilizadas para a reação. Uma vez capturados, são detectados pela adição de substâncias que emitem luz. Quanto maior o número de híbridos, maior será a intensidade luminosa a qual é captada e quantificada por um luminômetro no interior do equipamento. O resultado indica se a paciente está infectada por um ou ambos grupos de HPV e dá um valor semiquantitativo; quanto maior o valor da leitura, maior a chance de uma lesão celular induzida pelo HPV estar presente. De acordo com o fabricante, resultados com valores de RLU (Unidade Relativa de Luz) com cutoff maior ou igual a 1 indicam presença do vírus (Molijn et al., 2005). Como ponto negativo, o método não apresenta um controle interno de adequação da amostra (o que representa uma amostra viável para análise), podendo ocorrer resultados falsonegativos, ou seja na ausência de celularidade decorrentes de problemas na coleta, o teste será sempre negativo. Ainda, como previamente citado o método não identifica individualmente o tipo viral, e sabe-se que a infecção persistente por HPV oncogênico (ex: teste positivo para o mesmo tipo de HPV em momentos distintos) é um fator de risco para o câncer cervical. Os resultados expressos em grupos não permitem essa individualização (Ferreira \& Moraes, 2013). 


\subsubsection{Testes com base em PCR (Polymerase Chain Reaction)}

A Reação em Cadeia da Polimerase (PCR), utilizada a partir do final da década de 1980 (Saiki et al., 1988) tem sido comumente empregada para a detecção do HPV e outros agentes infecciosos além dos acima citados, como HIV, HBV, HCV e CMV entre outros. A contribuição dessa metodologia para o conhecimento da relação entre HPV e o câncer do colo do útero, bem como da epidemiologia do vírus em todo o mundo foi e tem sido enorme.

O material clínico a ser estudado pode ser obtido por meio de uma escova do tipo cervical (cytobrush), lavado vaginal, fragmentos de biópsia a fresco ou preparados em parafina. A PCR utiliza uma enzima responsável pela replicação do DNA, a DNA polimerase que é capaz de produzir milhares de cópias a partir de uma molécula de DNA do vírus presente na amostra (Villa e Denny, 2006)

A reação é baseada na amplificação da seqüência alvo utilizando iniciadores (primers) tipo-específicos ou consenso, estes últimos permitindo amplificar seqüências de DNA de diferentes tipos porque em geral o alvo é uma região conservada do genoma do HPV, a região L1. A sensibilidade e a especificidade da PCR podem variar dependendo dos iniciadores utilizados, da eficiência da DNA polimerase utilizada, do espectro de tipos de HPV amplificados e da habilidade de amplificar múltiplos tipos (Molijn et al., 2005). Os pares de iniciadores genéricos ou consenso MY09/MY11, PGMY09/PGMY11 e GP5+/GP6+, são capazes de detectar um grande número de tipos de HPV e tem sido os mais utilizados na maioria dos trabalhos que visam a detecção molecular do vírus. O par de iniciadores MY09/MY11 amplifica uma região de 450 pares de base da região L1 do vírus, a análise dos produtos amplificados pode ser feita em eletroforese em gel de agarose (Roda Husman et al., 1995; Gravitt et al., 2000). 
A diversidade dos genótipos e a incidência de infecções múltiplas tornaram necessário o estabelecimento de métodos confiáveis para identificação dos vários tipos virais, não somente para estudos epidemiológicos como também para o acompanhamento de pacientes. Devido a sua versatilidade e altíssima sensibilidade, vários sistemas baseados em PCR encontram-se disponíveis.

Algumas metodologias podem ser utilizadas para a tipagem após amplificação por PCR com iniciadores consenso. A hibridização com sondas (sequência complementar de ácido nucleico) tipo específicas é uma técnica empregada atualmente com capacidade de detectar uma grande variedade de HPVs anogenitais. A metodologia é baseada na hibridização reversa, em que sondas são imobilizadas em um suporte sólido e são colocadas em contato com os produtos de amplificação das amostras clínicas. O uso de iniciadores biotinilados possibilita a visualização através de uma reação colorimétrica. O LINEAR ARRAY® (Roche) emprega essa metodologia com capacidade de detectar 37 genótipos de HPVs anogenitais, $(6,11,16,18,26,31,33,35$, $39,40,42,45,51,52,53,54,55,56,58,59,61,62,64,66,67,68,69,70,71,72$ entre outros) (Stevens et al., 2006).

Menos utilizado nos dias de hoje, a identificação do genótipo viral pode ser feita com enzimas de restrição, sistema de digestão que utiliza um conjunto de enzimas que produzem um perfil tipo específico, e recebe o nome de RFLP (restriction fragment lenght polymorphism) necessitando ainda de eletroforese posterior (Bernard, 1994). É um método que apresenta baixa sensibilidade e especificidade com relação a infecções causadas por múltiplos tipos de HPV (Molijn et al., 2005). 


\subsubsection{PCR em tempo real}

Um avanço na metodologia da PCR convencional, é a PCR em Tempo Real, ou Real Time PCR. Esta técnica permite não só a detecção, mas também a quantificação do HPV e vários outros agentes infecciosos sem a necessidade de etapas pós amplificação como eletroforeses ou hibridizações.

A técnica se baseia na emissão de sinais fluorescentes constantes que ocorrem dentro da placas de reações ao longo dos ciclos de amplificação devido a presença de reagentes que emitem luz na medida em que ocorre amplificação do DNA do HPV. Existem vários sistemas para detecção desses produtos de PCR, entre estes os mais empregados são o sistema TaqMan®, o qual utiliza sondas e o sistema do corante SYBR® Green, um intercalante de DNA (Dorak, 2006). Os resultados são expressos na forma de gráficos, e a análise de positividade momento do ciclo da reação no qual a amplificação de um alvo ultrapassa um limite (cutoff/thereshold) ou negatividade pode ser monitorada em tempo real pelo operador.

Atualmente, existem testes comerciais disponíveis que realizam a genotipagem do HPV por PCR em tempo real qualitativo de forma totalmente automatizada, desde a extração ao preparo das placas de reações, ideais para serem empregados em centros com grandes demandas. Dentre eles o Cobas ${ }^{\circledR} 4800$ HPV Test (Roche Molecular Systems, EUA) e o BD Onclarity HPV Assay (BD Diagnostics, EUA) realizam desde o processo de extração do DNA até a montagem da reação, amplificação e detecção do DNA alvo através de PCR em tempo real. O teste BD Onclarity HPV Assay (BD Diagnostics, EUA) com alvo nas regiões E6 e E7 identifica individualmente seis genótipos de alto-risco (HPV16, 18, 31, 45, 51 e 52) ao mesmo tempo em que detecta 8 genótipos de HPVs de alto risco, distribuídos por três grupos denominados pelo 
fabricante de P1 (HPVs 33/58); P2 (HPVs 56/59/66) e P3 (HPVs 35/39/68) (Ejegod et al., 2013). O Cobas 4800® System (Roche Molecular Systems, USA), tem como alvo a região L1 do genoma viral detectando individualmente os HPV16 e 18, fornecendo também um resultado em pool para outros 12 genótipos de alto risco (HPVs 31, 33, 35, $39,45,51,52,56,58,59,66$ e 68) (Wrigth et al, 2012).

\subsubsection{Arrays}

Os ensaios de microarranjos de DNA ou microarrays, tem sido utilizados não somente em pesquisas mas também no diagnóstico. O teste PapilloCheck® (GreinerBio-One) é baseado na amplificação por PCR de um fragmento de aproximadamente 350 pares de base da região E1 do HPV. Detecta simultaneamente 24 tipos de HPVs, sendo 6 de baixo risco $(6,11,40,43$ e 44) e 18 de alto risco $(16,18,31,33,35,39,45$, $51,52,53,56,58,59,66,68,70,73$ e 82) (Dalstein et al., 2009).

Possui controles internos individuais que permitem avaliar a qualidade de todas as etapas do processamento da amostra: da qualidade do material do DNA extraído à hibridização do DNA. A etapa de hibridização é feita sobre uma lâmina (chip) e cada lâmina tem capacidade para 12 amostras contendo várias sondas (microarrays) em cinco réplicas, o que possibilita uma tipagem segura e confiável. A leitura da lâmina é realizada por meio de um scanner, o CheckScanner ${ }^{\mathrm{TM}}$, e o resultado emitido em fluorescência é automaticamente interpretado pelo software CheckReport ${ }^{\mathrm{TM}}$ (Dalstein et al., 2009). 


\subsubsection{Detecção do RNA mensageiro viral para as oncoproteínas E6 e E7 (E6/E7 mRNA) - NASBA (Nucleic Acid Sequence Based Amplification)}

O método NASBA utiliza a amplificação baseada na sequência de ácidos nucléicos. Diferentemente da PCR, é uma reação de amplificação isotérmica $\left(41^{\circ} \mathrm{C}\right)$, multiplex com detecção em tempo real, que utiliza as enzimas AMV-RT (Transcriptase Reversa do Vírus da Mieloblastose Aviária), a RNAse-H e a T7 RNA polimerase. É uma abordagem diagnóstica que detecta a presença dos RNAs mensageiros que codificam as duas oncoproteínas virais E6 e E7, as quais interferem nos sistemas de reparo do DNA conforme descrito anteriormente. Como a maioria das mulheres infectadas pelo HPV irá obter a eliminação viral espontânea através de mecanismos imunológicos, pesquisadores mundo afora buscam marcadores que possibilitem predizer quais mulheres estariam sob o risco de evolução maligna. Desta forma, foram desenvolvidos testes capazes de identificar o aumento da atividade dos oncogenes virais E6 e E7 (E6/E7 mRNA) com o intuito de oferecer testes de maior especificidade clínica, evitando-se as dificuldades provenientes de um diagnóstico HPV-DNA positivo sem significado clínico (Ratnam et al., 2010).

Dois testes comercialmente disponíveis são o NucliSENS® EasyQ HPV test (BioMérieux) e o Aptima® (GenProbe). A detecção da positividade também é obtida por sinais de fluorescência na medida em que os transcritos de RNA são detectados (Jeantet et al., 2009), sendo os resultados expressos na forma de gráficos, podendo ser visualizado em tempo real pelo operador. 


\subsubsection{Hibridização in situ}

A técnica de hibridização in situ (ISH) detecta sequências específicas de DNA ou RNA utilizando sondas (sequência complementar de ácidos nucleicos) HPVespecíficas marcadas radioativas ou quimicamente. Pode ser realizada em material parafinado, raspados citológicos ou em biópsias congeladas. É uma metodologia que permite a localização do DNA ou RNA do vírus de forma específica em células definidas, o que torna possível a associação dos dados moleculares com os achados citohistológicos. No entanto, é uma técnica de sensibilidade baixa e bastante trabalhosa (Ferreira \& Moraes, 2013).

\subsection{Uso dos testes de HPV no rastreio primário do câncer cervical}

Desde que se tem conhecimento do HPV como agente causal do câncer de colo do útero, o teste de HPV passou a ser postulado como uma efetiva ferramenta para a prevenção deste tipo de câncer (Bosch et al., 2002; Walboomers et al., 1999; Bosch et al., 2003). Uma questão que permanece e que vem sendo discutido por vários países é como deve ser utilizado, avaliando aspectos econômicos e resultados médicos, se como teste primário ou adjuvante ao exame citológico (Cuzick et al., 2008b). Na prática clínica tem sido utilizado como método de triagem para pacientes com citologia alterada/indeterminada, por exemplo as citologias classificadas como ASC-US. Um teste de HrHPV positivo em combinação com o achado de ASC-US deve ser investigado, enquanto um resultado de HrHPV negativo pode ser interpretado como 
sem maior significado clínico, o mesmo também podendo ser estendido para os casos de citologias LSIL, que na ausência do DNA de HrHPV pode ser optada por uma conduta expectante (Arbyn et al., 2005). Outro emprego do teste de HrHPV tem sido para monitorar tratamento de neoplasia intraepitelial cervical, indicando falha na terapêutica mediante resultado positivo, em contrapartida, um resultado negativo é um indicador de eficácia (Arbyn et al., 2005).

O campo da prevenção do câncer cervical, está em fase ativa de avaliação de novas tecnologias para aumentar a eficiência do rastreio em países desenvolvidos e oferecer opções reais para as populações que não são beneficiadas por programas de rastreamento organizados. Diferentes estudos randomizados controlados realizados na Suécia, Itália, Reino Unido, Finlândia, Canadá, Holanda e Estados Unidos tem mostrado o potencial do emprego do uso do teste de HrHPV como método de rastreio primário do câncer cervical (Bulkmans et al, 2004; Ronco et al, 2006; Rijkaart et al 2012; Wright et al., 2012; Ronco et al., 2014).

Existem decisões a serem tomadas a respeito do rastreio primário em diferentes cenários. Nos países onde a citologia tem boa qualidade, a solução mais interessante seria fazer o rastreio com teste molecular e reservar a citologia como teste de triagem para as mulheres com positividade para o DNA do HPV. No entanto, nos países com menor infraestrutura, a detecção do DNA isoladamente pode ser interessante, caso se faça o tratamento imediatamente, para minimizar o número de consultas e exames e racionalizar o uso de recursos públicos (Cuzick, et al., 2006). 


\section{$2.7 \quad$ Justificativa}

A Secretaria de Estado da Saúde de São Paulo (SES) é responsável pela coleta e análise de aproximadamente 2,5 milhões de exames de Papanicolaou por ano, e a Fundação Oncocentro de São Paulo - FOSP (3- maior volume) realiza cerca de 250 mil desses exames. Em virtude das diversas limitações da técnica de citologia convencional, o estudo aqui proposto visou avaliar a viabilidade de coleta em meio líquido, a utilização de avaliação citológica assistida por computador e potenciais algoritmos de manejo das pacientes de acordo com os resultados do teste molecular para HrHPV, na rede pública do Estado de São Paulo.

O estudo foi realizado em uma população atendida pelo Sistema Único de Saúde (SUS) na cidade de São Paulo, visando à avaliação destas tecnologias em condições habituais de rastreio, o que pode permitir a projeção mais ampla dos resultados para a população em geral. 
3 Objetivos 


\subsection{Objetivo geral}

Possibilitar a construção de um novo algoritmo para implantação no programa de detecção de câncer de colo uterino no Estado de São Paulo.

\subsection{Objetivos específicos}

- Avaliar a viabilidade de coleta em meio líquido;

- Avaliar o desempenho de novo teste molecular para detecção do DNA de HrHPVs e comparar com os resultados citopatológicos e histopatológicos;

- Avaliar o desempenho diagnóstico do método de LBC para detecção de lesões de alto e baixo grau em comparação com o diagnóstico histopatológico;

- Avaliar a citologia assistida por computador versus o desempenho do teste manual; 
$4 \quad$ Materiais e Métodos 


\subsection{Metodologia}

\subsection{Comitê de Ética}

O estudo foi submetido e aprovado pela Comissão de Ética para Análise de Projetos de Pesquisa da Faculdade de Medicina da USP (CEP - USP), CAAE: 08163713.0.0000.0065, número do parecer 231.303. Todas as mulheres que participam deste estudo foram previamente informadas dos objetivos e as possíveis aplicações futuras dos resultados esperados pelo projeto. Todas as participantes assinaram um Termo de Consentimento Livre e Esclarecido (ANEXO 1).

\subsubsection{Registro internacional}

O estudo está registrado no site do endereço http://prsinfo.clinicaltrials.gov/, no serviço de registro Internacional de "trials" científicos" International Committee of Medical Journal Editors (ICMJE) initiative, o que possibilita expor e discutir nossos resultados internacionalmente.

\subsection{Amostragem e critérios de inclusão}

Trata-se de um estudo prospectivo aberto do tipo observacional, sem randomização, em que foram obtidas amostras cervicais de mulheres de qualquer idade que procuraram as Unidades Básicas de Saúde (UBSs) participantes do Projeto Região Oeste (FMUSP): Jardim Boa Vista, Paulo VI, Vila Dalva, Jardim D`Abril, Jardim São Jorge, Vila Sônia e Ambulatório da Maternidade Interlagos para a realização do exame 
preventivo do colo do útero, entre dezembro de 2014 e março de 2016, totalizando 15.991 mulheres, o ANEXO 2 demonstra o histórico da população alvo. Para o rastreio foram realizados a citologia oncótica colhida em meio líquido e teste para HrHPV; como exames confirmatórios a colposcopia seguida ou não de biópsia. Uma nota explicativa (ANEXO 3) para as mulheres com resultado positivo para o teste de HrHPV e condutas são incorporadas aos laudos. Durante esse período, 1.100 mulheres repetiram o exame com intervalo inferior a um ano, destas a primeira amostra foi considerada, e para os casos em que apenas a segunda amostra apresentou o seguimento completo esta permaneceu no estudo.

\subsection{Coleta e preparo das amostras citológicas}

Após o consentimento da participante, foi colhida uma amostra para o exame colpocitológico em base líquida (BD SurePath ${ }^{\text {TM }}$ - TriPath, Burlington, NC, EUA.). A coleta de células da junção ectocervical/endocervical foi dispensada no recipiente contendo $10 \mathrm{~mL}$ do fixador líquido (base de etanol). Toda a cabeça da escova foi dispensada no frasco contendo líquido BD SurePath TM (BD Diagnostics - TriPath, Burlington, NC, E.U.A.) e enviada ao laboratório da FOSP semanalmente.

No laboratório, as amostras foram previamente homogeneizadas no vórtex por 20 segundos e encaminhadas para o processamento no sistema BD Totalys ${ }^{\circledR}$ que é totalmente automatizado, composto dos equipamentos Multiprocessor e SlidePrep. O Multiprocessor é um instrumento que integra o pré processamento da amostra da citologia ao teste molecular. Utiliza $9 \mathrm{~mL}$ e realiza o "enriquecimento celular", ou seja, a retirada dos possíveis interferentes e a formação do pellet de células com interesse diagnóstico para a citologia em meio líquido SurePath ${ }^{\circledR}$ e uma alíquota de $0,5 \mathrm{~mL}$ para 
o teste molecular BD Onclarity HPV ${ }^{\mathrm{TM}}$ que é adicionada a 1,7 $\mathrm{mL}$ do tubo diluente BD HPV LBC ${ }^{\circledR}$. O processo de automação total visa manter a integridade da amostra e melhorar a eficiência no laboratório. Após, o material pré processado para a citologia oncótica foi encaminhado ao meio automatizado BD Totalys SlidePrep ${ }^{\mathrm{TM}}$ (BD Diagnostics - TriPath, Burlington, NC, E.U.A) para confecção e coloração da lâmina; e as alíquotas para o estudo molecular foram armazenadas e conservadas a $4^{\circ} \mathrm{C}$ até serem utilizadas no Sistema Viper LT system (BD Diagnostics, Sparks, MD). Os detalhes do ensaio BD Onclarity HPVTM e sistema BD Viper LT são reportados adiante. A Figura 5 mostra o fluxo das amostras utilizando o sistema BD Totalys ${ }^{\circledR}$

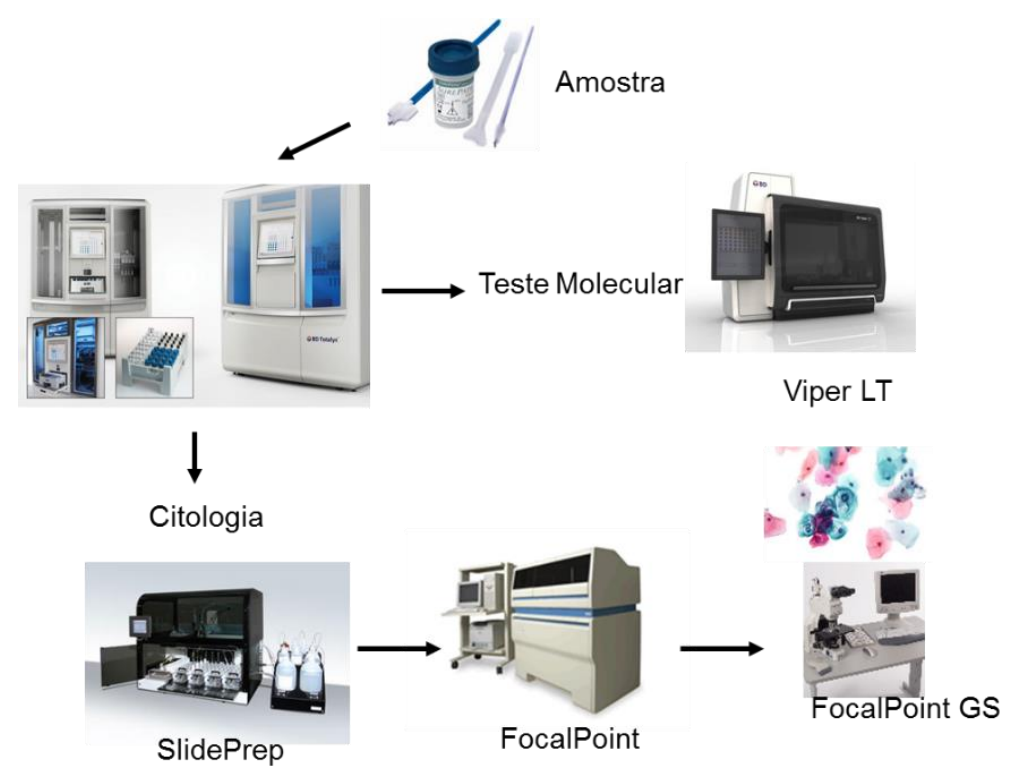

Figura 5- $\quad$ Fluxo das amostras no laboratório da FOSP após processamento pelo Sistema BD Totalys (Figuras disponíveis em www.bd.com). 


\subsection{Avaliação pelo BD FOCALPOINT TM GS}

Todas as preparações em base líquidas BD SurePath foram avaliadas com assistência de equipamento computadorizado, o BD FocalPoint Imaging System TM GS (BD Diagnostics - TriPath, Burlington, NC, EUA), que separa, por ordem decrescente de gravidade, 10 campos de visão que serão avaliados pelos citotécnicos e anatomopatologistas com treinamento prévio na metodologia de citologia em meio líquido. Esses campos são classificados em 5 quintis, de 1 a 5, de maior para menor chance de haver lesão (os quintis 1 e 2 são os que mais provavelmente apresentam lesões). O sistema não fornece o diagnóstico. Todos os casos foram também analisados por citotécnicos com os respectivos relatórios emitidos pelo BD FocalPoint Imaging System ${ }^{\text {TM }}$ GS (BD Diagnostics - TriPath, Burlington, NC, EUA) e sem conhecimento do resultado de HPV. Em caso de suspeita de lesão foram revistos por citologistas e anatomopatologistas.

\subsubsection{Classificação das citologias}

Utilizou-se a classificação baseada na Nomenclatura Brasileira para laudos cervicais e condutas preconizadas (ANEXO 4), que tem como base a codificação do Sistema de Bethesda 2001. Possui as seguintes categorias diagnósticas: dentro dos limites da normalidade; alterações celulares benignas reativas; atipias celulares de significado indeterminado de origem escamosa (ASC-US e ASC-H) ou glandular (AGC); lesões intraepiteliais escamosas de baixo grau (LSIL); lesões intraepiteliais escamosas de alto grau (HSIL - Carcinoma in situ); carcinomas epidermóides invasores (CEC); adenocarcinomas in situ e invasores (MS-Inca, 2011). 


\subsubsection{Discrepâncias de classificação}

Nos casos em que tanto a análise citológica manual quanto a computadorizada teve a mesma classificação, o diagnóstico foi considerado definitivo e liberado. Sempre que discordantes, um diagnóstico definitivo foi obtido por consenso por uma equipe de citopatologistas, todos envolvidos no projeto, analisando os casos com um microscópio multi-ocular.

\subsubsection{Teste molecular para HRHPV}

\subsubsection{BD Onclarity HPV Assay (BD Diagnostics, Sparks,MD)®}

Grande parte dos ensaios de HPV que utiliza iniciadores (primers) consenso na técnica de PCR tem como alvo a região L1 do genoma viral, o que pode ser um limitante técnico em algumas situações como deleção da região L1 durante a integração do genoma do HPV nos casos de câncer cervical (Ejegod et al., 2013). O teste molecular BD Onclarity ${ }^{\circledR}$ é apresentado como uma alternativa para esses casos, sendo realizado de forma $100 \%$ automatizada a partir de amostras de LBC Surepath no sistema BD Viper $\mathrm{LT}^{\circledR}$, de acordo com as instruções do fabricante. A rastreabilidade das amostras é garantida em todas as fases do processo através da identificação do código de barras do tubo primário.

É um ensaio baseado na reação de cadeia de polimerase (PCR) em tempo real, que detecta o DNA de 14 tipos de HPV de alto risco e o gene endógeno da beta globina humana utilizado para controle da presença de inibidores da PCR, avaliação da adequação, extração e amplificação da amostra. Os primers desenhados para os 14 
genótipos de HPV tem como alvo uma região de 79 a 137 pares de bases das regiões E6 e E7 do genoma viral, enquanto para o gene da beta globina amplificam uma região de 75 pares de bases. Os HPVs 16, 18, 31, 45, 51 e 52 são reconhecidos individualmente, e os HPVs 33 e 58; 5659 e 66; 35, 39 e 68 e detectados de forma agrupada, sendo representados por $\mathrm{P} 1, \mathrm{P} 2$ e $\mathrm{P} 3$ respectivamente.

\subsubsection{Preparo das amostras}

As amostras foram previamente aquecidas a $120^{\circ} \mathrm{C}$ por aproximadamente 30 minutos e em seguida resfriadas por mais 30 minutos a temperatura ambiente no equipamento BD Pre-warm Heater, onde ocorre a lise das células e exposição do DNA a ser extraído e amplificado. Após o resfriamento, as amostras são colocadas no sistema Viper LT BD, que em seguida realiza todos os passos envolvidos na extração e amplificação do DNA alvo, sem qualquer outra intervenção do operador como descrito a seguir.

\subsubsection{Extração, amplificação e detecção}

O DNA é extraído utilizando óxido férrico (BD Viper XTR ferric oxide (FOX)) da seguinte forma: a amostra é transferida para um tubo de extração que contém partículas de óxido férrico numa película solúvel. É então adicionado ácido que reduz o pH e induz uma carga positiva sobre o óxido férrico, o qual por sua vez se liga a carga negativa do DNA. As partículas de óxido férrico agora ligadas ao DNA são atraídas para a lateral do tubo de extração por atração magnética; em seguida o material não 
ligado é desprezado. Posteriormente, o material remanescente é lavado e $400 \mu l$ do tampão de eluição com pH elevado é adicionado, eluindo o DNA purificado. Por fim, um tampão de neutralização é utilizado para ajustar o pH do eluato para a amplificação do DNA.

O ensaio BD Onclarity HPV comporta 32 amostras por corrida (incluindo os controles) e tem a capacidade de detectar 100 cópias de um tipo de HPV na presença de um milhão de cópias de alvos de HPVs concorrentes, o que garante que infecções mistas possam ser detectadas de forma segura. Os reagentes são fixados (secos) na placa de PCR, a qual é dividida em três diferentes poços de três cores diferentes na placa de PCR (G1, G2, G3) (Figuras 6a e 6b) e quatro canais ópticos os quais são capazes de detectar os 14 genótipos de HPV e o controle interno da amostra. Cada poço na placa de PCR contém os respectivos primers, sondas com detectores fluorescentes, DNA polimerase, dNTPs e outros reagentes necessários para amplificação. Um volume de 50 $\mu \mathrm{L}$ do material extraído foi dispensado em cada um dos três poços de PCR o que rehidrata o Master-Mix e HotStar Taq DNA Polimerase; a placa é então selada para prevenir contaminação. As condições de amplificação da PCR foram: ativação da enzima a $95^{\circ} \mathrm{C}$ durante 15 minutos seguido por 40 ciclos de $95^{\circ} \mathrm{C}$ por 30 segundos e $55^{\circ} \mathrm{C}$ por 60 segundos. A presença ou ausência do DNA do HPV é determinada pelo ciclo de PCR no qual o sinal ultrapassa o limiar "threshold" previamente estabelecido (Wright et al., 2014; Castle et al., 2011). 

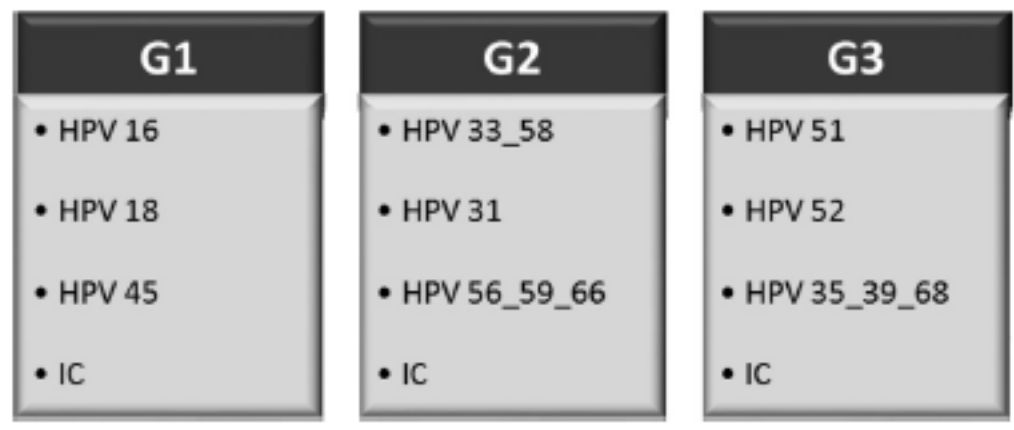

Figura 6a- $\mathrm{O}$ ensaio é composto por 3 poços, designados $\mathrm{G} 1$ a G3, cada um dos quais tem um controle interno da beta globina (IC) lidos em único canal. Os 14 tipos de HrHPV são lidos nos outros 3 canais individualmente ou em grupos de dois ou três tipos de HPV agrupados como mostrado (Bottari et al., 2015).

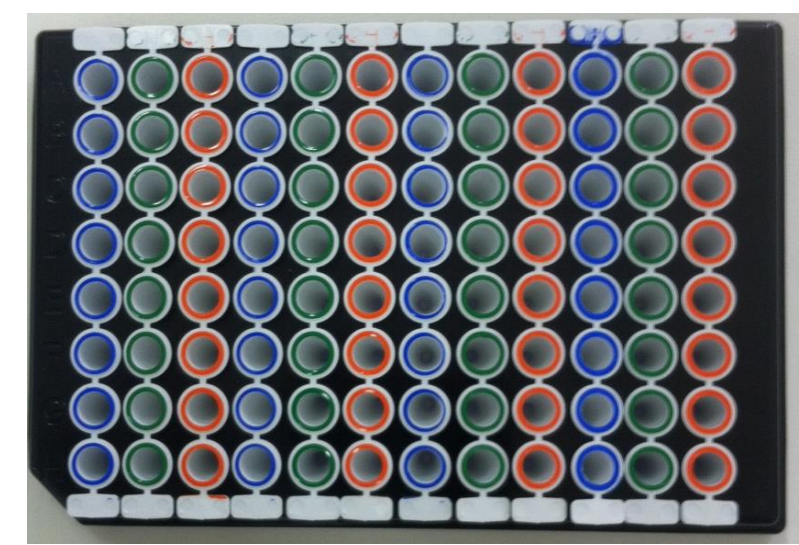

Figura 6b- Representação esquemática da placa de PCR, cada poço representa G1 (azul), G2 (verde) e G3 (laranja).

\subsection{Colposcopia}

Exame colposcópico foi realizado em todas as mulheres com teste molecular de HrHPV positivo e idade entre 25 e 64 anos, independentemente do resultado do teste citológico. Para as mulheres com teste molecular de HrHPV negativo só foi realizado 
exame colposcópico nos casos preconizados pelas Diretrizes Brasileiras para o Rastreamento do Câncer do Colo do Útero (MS-Inca, 2011) a qual leva em consideração faixa etária e classificação citológica. A Unidade Básica de Saúde Vila Sônia, a Maternidade Interlagos e o Hospital Universitário da Universidade de São Paulo são os locais de referência que atendem as demandas dos exames colposcópicos.

\subsection{Biópsia}

As coletas de tecido para análise histopatológica (biópsias) foram feitas mediante avaliação do médico colposcopista ciente dos resultados laboratoriais de citologia e HPV. Os achados histopatológicos, realizados pela equipe da FOSP, são o padrão-ouro para cálculo da sensibilidade e especificidade das metodologias empregadas. Nos serviços de referência acima citados (ítem 4.6), os frascos foram devidamente identificados no momento da coleta, indicando a localização do material em caso de amostras múltiplas (exemplos: biópsia do colo do útero 6h e biópsia do colo do útero 9h). O material foi acondicionado em frascos com solução tamponada de formol diluído a 10\%, devidamente fechados para evitar vazamento e contendo volume de formol 10 vezes superior ao volume do fragmento de biópsia e enviados semanalmente para a FOSP. No laboratório, as lâminas foram preparadas, fixadas em parafina e coradas por hematoxilina-eosina e a classificação utilizada foi a de (Richart 1967), NIC 1, NIC 2, NIC 3, Carcinoma e Adenocarcinoma. Cada biópsia foi avaliada por dois patologistas, para os diagnósticos concordantes o resultado foi liberado e para os casos discordantes um terceiro patologista foi consultado para um consenso no diagnóstico. 


\subsection{Fluxograma metodológico}

\subsubsection{Mulheres com 25 anos ou mais}

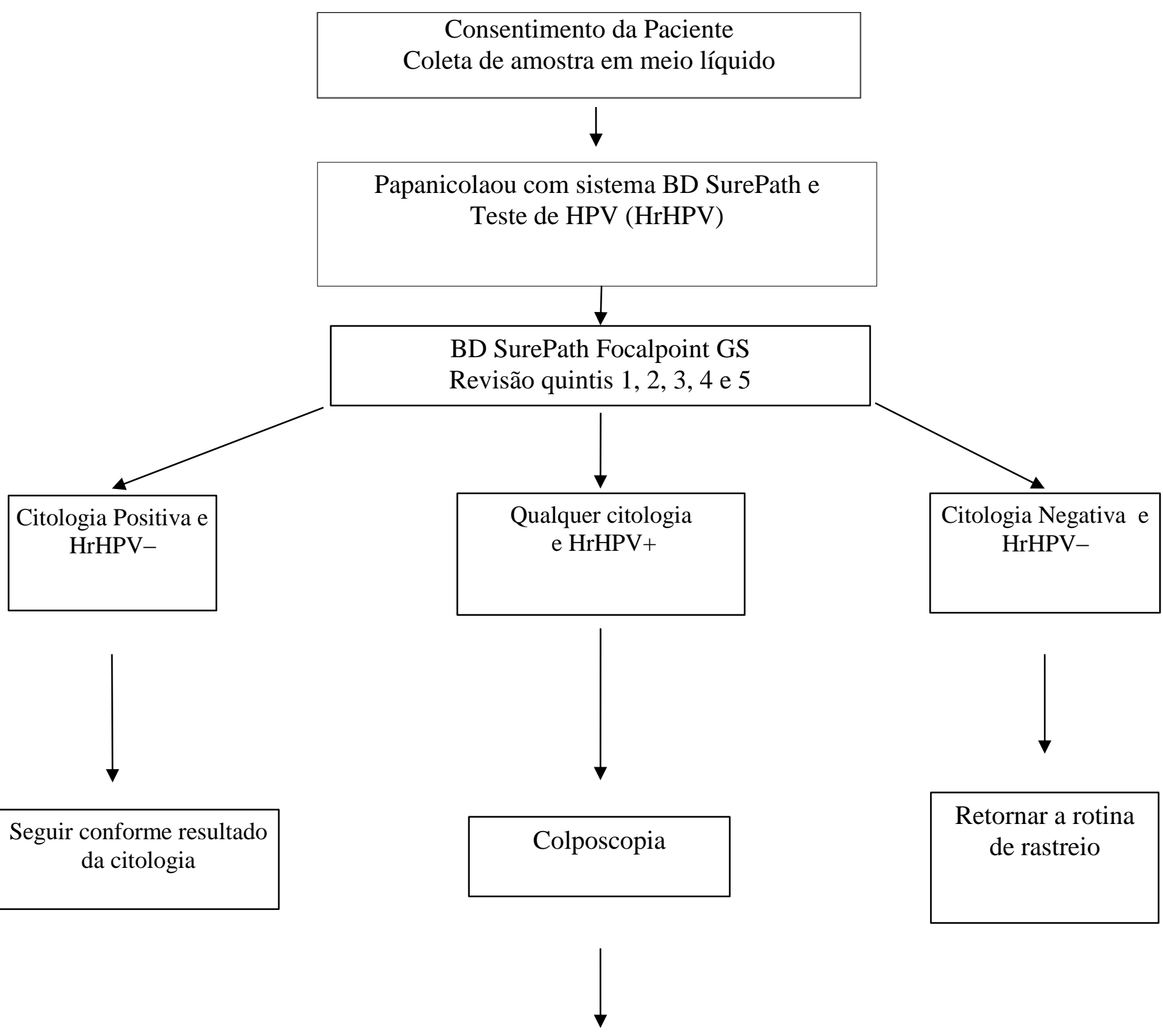

Biópsia 


\subsubsection{Mulheres com menos de 25 anos}

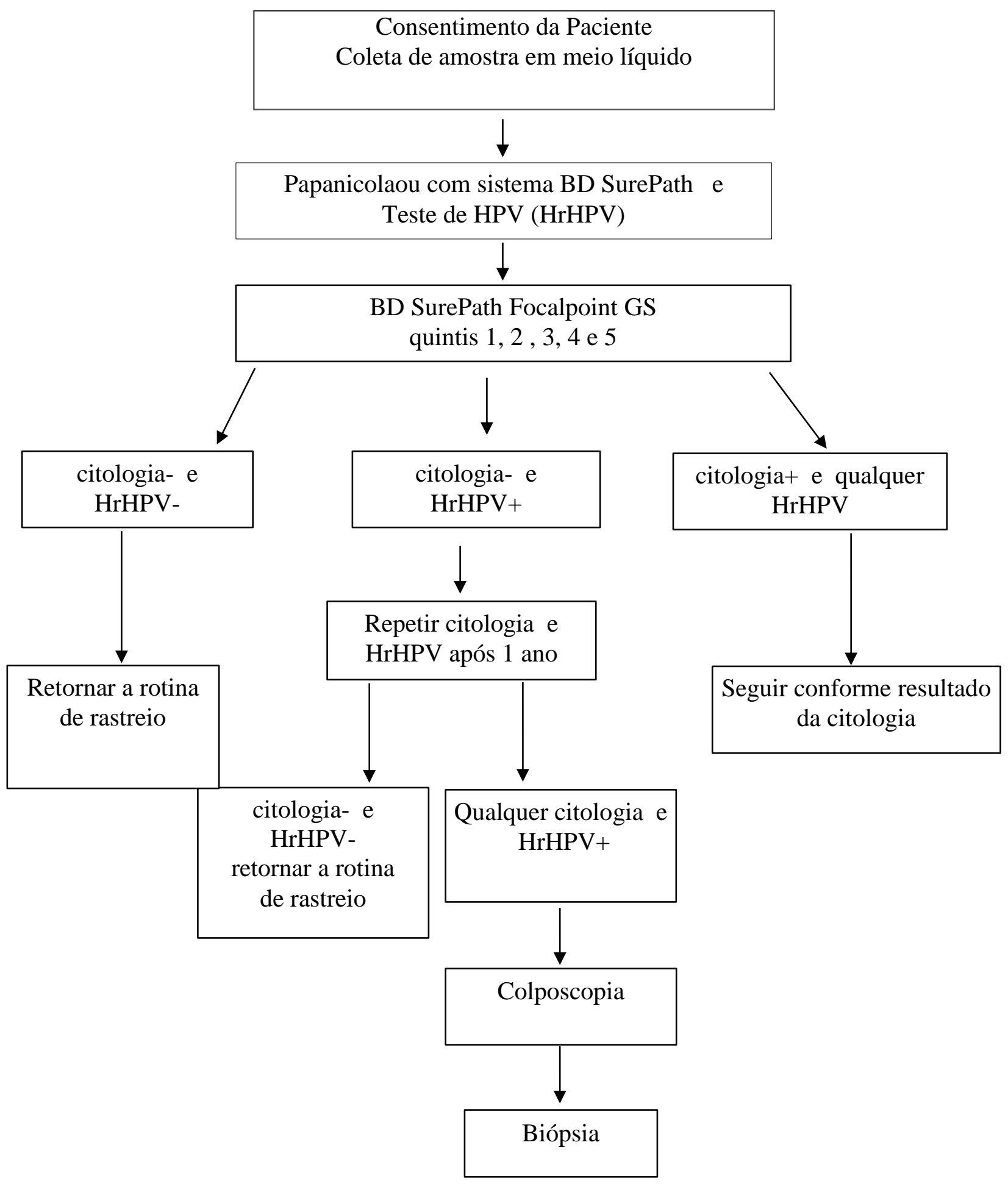




\subsection{Estratégias de rastreamento do câncer cervical}

Com o propósito de reduzir custos e traumas psicológicos decorrentes de um teste de HPV positivo, considerando que a maioria das infecções são transitórias como previamente abordado, pesquisadores tem avaliado diferentes testes de triagem com a finalidade de evitar encaminhamentos desnecessários para o exame colposcópico.

Desta forma, 10 diferentes estratégias com base em revisão de dados da literatura (Cox et al., 2013, Huh et al, 2015), incluindo o uso do teste de HPV como método de rastreio primário, a citologia e/ou combinação de ambos foram analisadas como potenciais abordagens para a prevenção do câncer cervical. Em resumo, a estratégia 1 utilizou o teste de HPV isolado para o rastreio primário, neste modelo todas amostras HPVs positivas são encaminhadas para a colposcopia, enquanto a estratégia 2 baseada no modelo de prevenção tradicional, a citologia, encaminhou as mulheres com classificação citológica ASC-US+ para avaliação complementar. Combinando a citologia com o teste de HPV (coteste), a estratégia 3 direciona para a colposcopia mulheres com ambos testes positivos e os casos citológicos > ASC-US independente do resultado do HPV. Com uso bem estabelecido na prática clínica, a estratégias 4 também baseada na citologia como teste primário, utiliza o teste HPV como reflexo para os casos ASC-US, sendo as citologias > ASC-US referidas ao exame colposcópico.

As estratégias 5, 6, 7 e 8 utilizam o teste de HPV como rastreio primário com ou sem genotipagem dos HPVs 16 e 18, diferindo em relação ao método de triagem adotado para exames subsequentes. A estratégia 9, como a estratégia 2, parte do rastreio citológico isolado, mas encaminhando para a colposcopia as mulheres 
com citologia ASC-H, AGC e HSIL ou lesão mais grave, recomendação esta das Diretrizes Brasileiras para o Rastreamento do Câncer do Colo do Útero (MS-Inca, 2011). Da mesma forma que esta última, a estratégia 10 utiliza os mesmos critérios, mas compreendendo a faixa etária de 25 a 64 anos, recomendada para o rastreio no Brasil.

As estratégias descritas podem ser ferramentas atraentes para os gestores de saúde com o intuito de uma prevenção mais eficaz contra o câncer de colo do útero. Mulheres com resultados dos testes negativos ou que não preencham os critérios para colposcopia imediata devem retornar a rotina de rastreio ou seguimento em um ano. Uma descrição mais detalhada de cada estratégia pode ser observada nas Tabela nos itens 5.9 e 5.10 .

\subsection{Análise estatística e avaliação do algoritmo}

A elaboração do banco de dados e a análise dos resultados foram realizadas por meio do software estatístico Stata/IC 12.0. Coletaram-se dados demográficos presentes na requisição de exame citopatológico padrão do SUS (idade e escolaridade), sobre realização de exame citológico preventivo anterior (ANEXO 5), resultados dos testes de HPV, citologia líquida, Focal Point e colposcopias seguidas de biópsia. Embora o estudo tenha realizando a citologia em paralelo ao teste molecular, de forma a atender as diretrizes governamentais de rastreio, a análise dos resultados tomando se como padrão ouro a biópsia permitiu calcular a sensibilidade, especificidade e os valores preditivos 
de ambas as metodologias se empregadas isoladamente, uma vez que as mulheres HPV+/Citologia- também foram encaminhadas à colposcopia.

As performances de cada estratégia para detecção de NIC 2+ e NIC 3+ foram exploradas como potenciais abordagens para a prevenção do câncer cervical estimandose valores de sensibilidade, especificidade, valores preditivos negativo (VPN) e positivo (VPP), número de colposcopias para detectar cada lesão de alto grau, número de testes realizados, possibilitando estimativas do número de lesões não detectadas e das que poderiam ser potencialmente diagnosticadas por cada uma delas. Os intervalos de confiança foram calculados através da distribuição binomial exata. Os valores de razão de chances (odds ratio) para NIC2+ e seus respectivos intervalos de confiança foram calculados para diferentes categorias de resultados do teste de HPV. 
5. Resultados 
Foram analisadas 15.991 amostras de raspado cervical, provindo de igual número de mulheres, para análise citológica e teste molecular para pesquisa do DNA de HPV de alto risco, obtidas de mulheres de 12 a 90 anos, com média de idade de 41,9 anos, desvio padrão 14,7, mediana 41 anos. A faixa etária inferior ou igual a 24 anos (< $\mathrm{ou}=\mathrm{a} 24$ anos) representou 2.112 amostras (13.2\%) enquanto a faixa etária de 25 a 64 anos preconizada para o rastreio do câncer do colo do útero pelas diretrizes brasileiras representaram 12.666 amostras (79.2\%). Mulheres com idade superior a 64 anos totalizaram 1.213 amostras (7,6\%). Das mulheres que souberam responder o questionário padrão do SUS, 13.236 mulheres $(87,3 \%)$ reportaram ter realizado exame preventivo anterior, enquanto $1.919(12,7 \%)$ relataram não ter exame prévio. Dados de $836(5,2 \%)$ mulheres não foram informados.

\subsection{Amostras por unidade de saúde}

Das 15.991 amostras recebidas, a Maternidade Interlagos foi responsável pelo envio de $6.200(38,8 \%)$, seguida pela UBS Vila Sônia que enviou 3.402 (21,3\%) amostras. O Gráfico 1 apresenta a distribuição das amostras colhidas por Unidade de Saúde. 
Gráfico 1- Distribuição das 15.991 amostras colhidas por Unidade de Saúde.

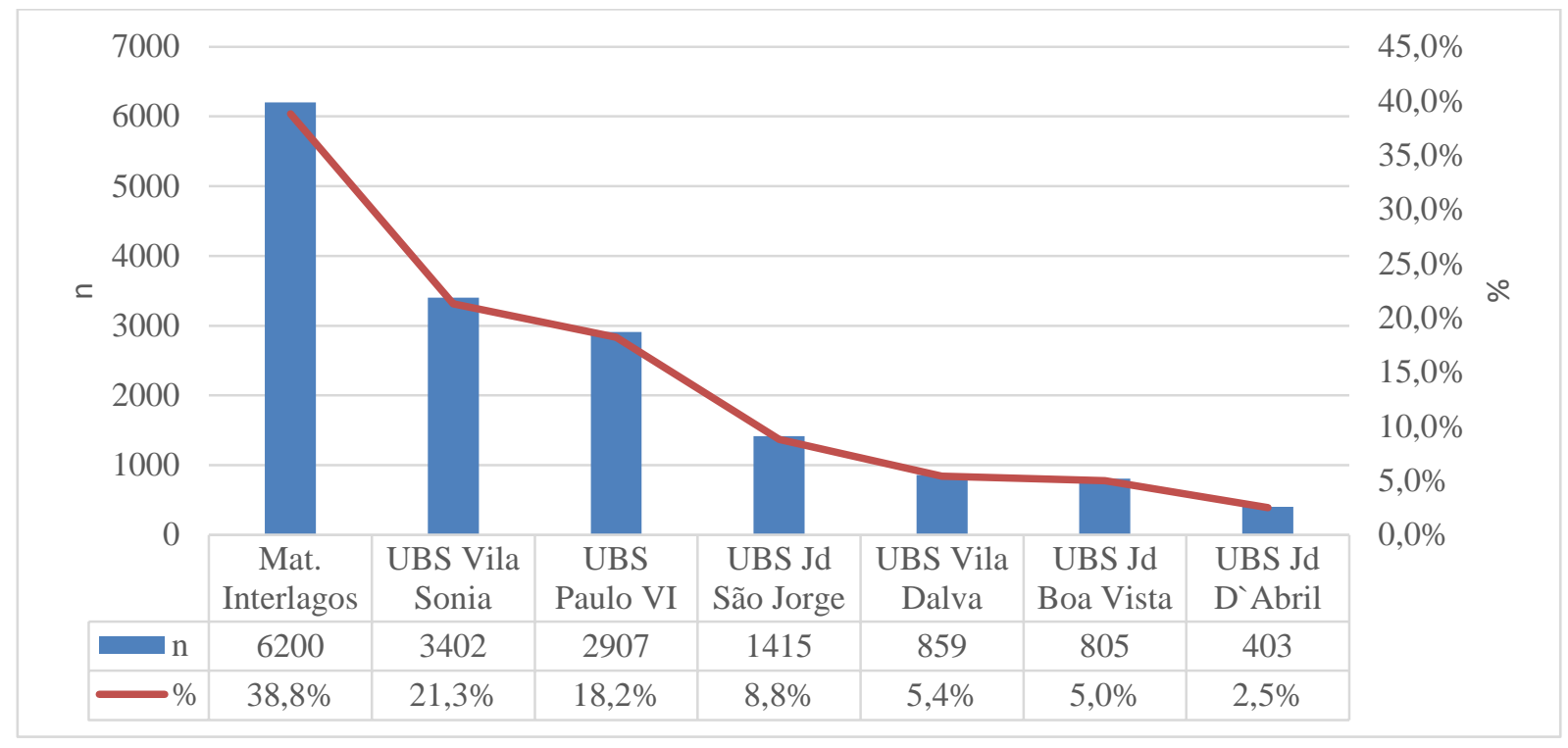

\subsection{Avaliação da amostra e junção escamo colunar por unidade}

A avaliação da qualidade das amostras dos preparados em meio líquido mostrou um índice de amostras satisfatórias para avaliação de 15.945 (99,7\%), enquanto $46(0,3 \%)$ foram consideradas insatisfatórias e excluídas da avaliação citológica. Ao avaliar a presença de células da Junção Escamo Colunar (JEC) entre as Unidades de Saúde participantes, $11.545(72,4 \%)$ amostras tiveram representatividade do epitélio da zona de transformação. A Maternidade Interlagos apresentou o menor índice 67,7\% das amostras e a UBS Paulo VI o maior percentual 79,6\%. A distribuição de células da JEC por Unidade de Saúde é representada no Gráfico 2.

Quando estratificadas por diferentes faixas etárias, as mulheres com idade inferior ou igual a 24 anos $(<$ ou = a 24 anos $)$ apresentaram presença de células da JEC em 1.664 amostras $(79,1 \%)$, o grupo etário de 25 a 29 anos $(81,4 \%)$, as mulheres de 30 a 34 anos $82,4 \%$, de 60 a 64 anos (49,7\%), enquanto com 65 anos ou mais (>ou= a 65 
anos) $569(47 \%)$ das amostras. O Gráfico 3 representa a avaliação da JEC por faixa etária.

Gráfico 2- Distribuição da presença de células da JEC por Unidade de Saúde em 15.945 amostras.

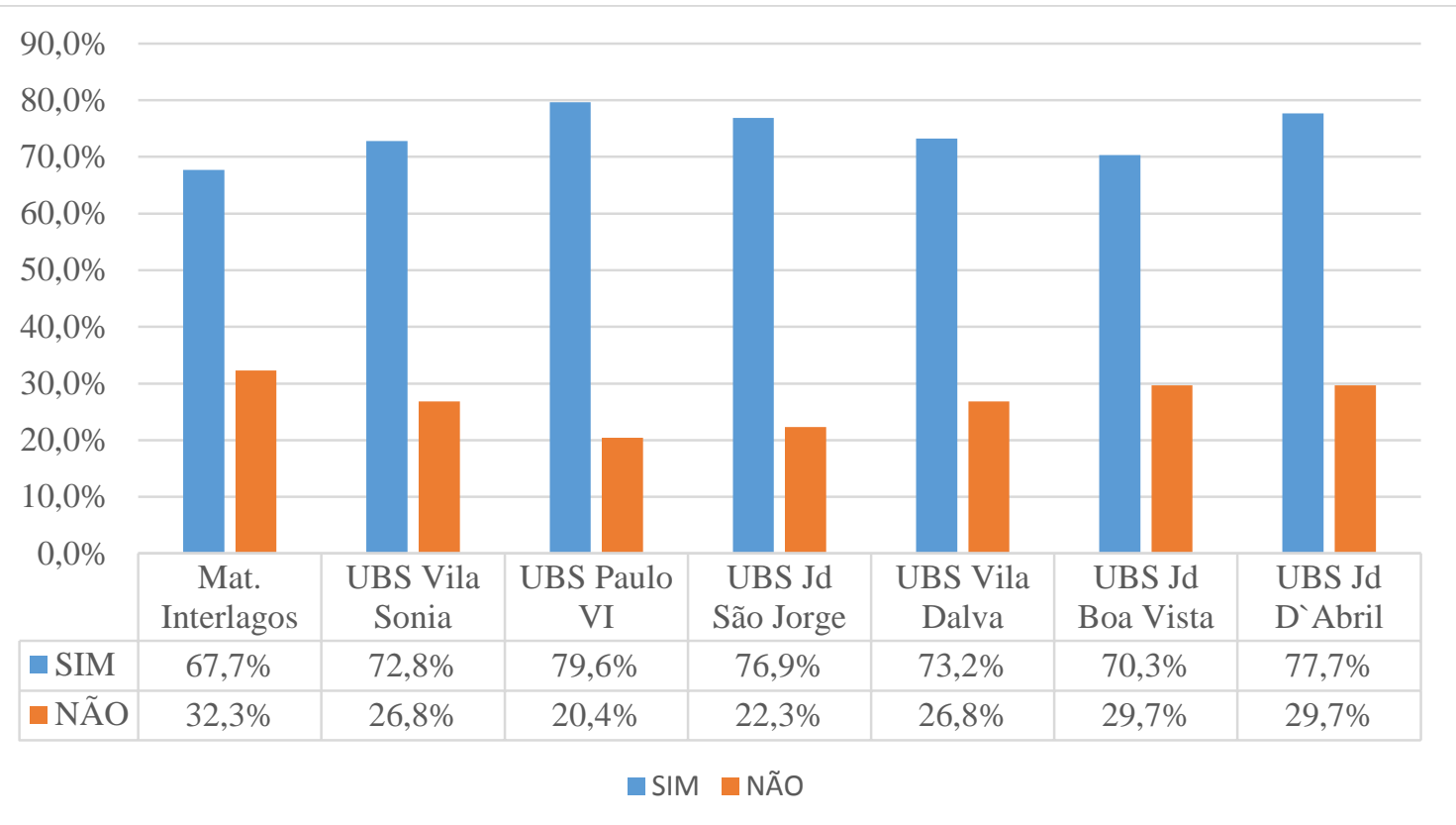

Gráfico 3- Distribuição da presença de células da JEC por faixa etária em 15.945 amostras.

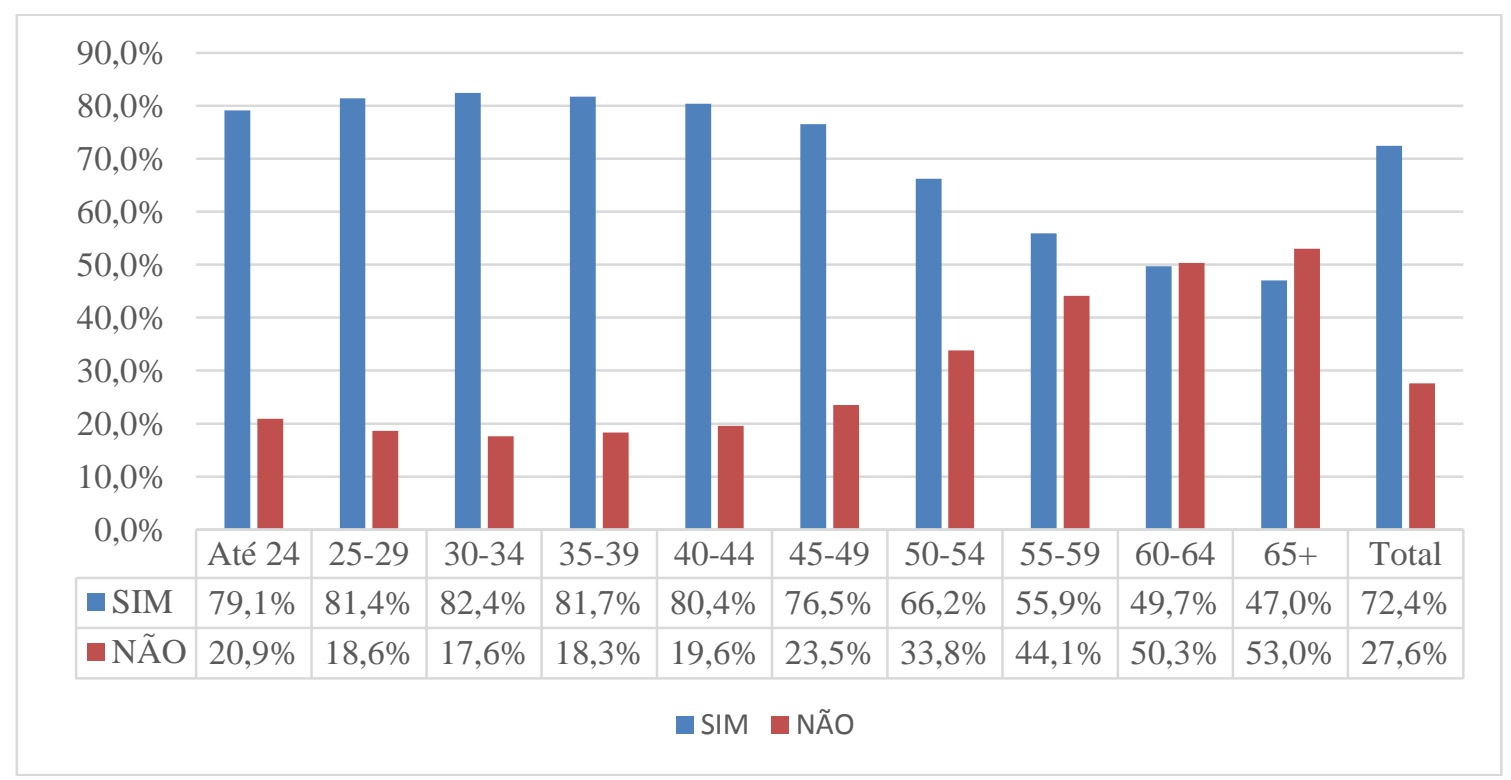




\subsection{Citologia oncótica ou citopatologia}

As amostras que apresentaram atipias em células escamosas de significado indeterminado (ASC-US e ASC-H), lesão intraepitelial escamosa de baixo grau (LSIL), lesão intraepitelial escamosa de alto grau (HSIL), carcinoma in situ (CIS), carcinoma epidermóide invasor (CEC), atipia glandular de significado indeterminado (AGC) e Adenocarcinomas (ADC) foram consideradas positivas. As amostras que apresentaram um padrão normal ou alterações celulares reacionais/inflamatórias foram consideradas negativas.

Entre as amostras satisfatórias para avaliação, 92,8\% (14.793/15.945) apresentaram resultados normais na citologia oncótica, tendo sido classificadas como negativas e $7.2 \%(1.152 / 15.945)$ das amostras apresentaram alguma anormalidade e foram classificadas como positivas, distribuídas da seguinte forma: ASC-US 546 (3,4\%) amostras; ASC-H 119 (0,7\%); LSIL 392 (2,5\%); HSIL em 87 (0,5\%), CEC 2 (0,01\%) e seis casos $(0,04 \%)$ de AGC.

Quando estratificados por idade, observa-se um decréscimo na detecção das anormalidades citológicas, os resultados da citologia oncótica mostram 13,6 \% $(286 / 2.104)$ de positividade na faixa etária $<$ ou = a 24 anos; $9,2 \%(148 / 1.602)$ na faixa etária de 25 a 29 anos; 6\% (109/1.806) de 30 a 34 anos, 4,0\% (41/1.014) de 60 a 64 anos e 3,7\% (45/1.210) para as mulheres com 65 anos ou mais ( $>$ ou $=$ a 65 anos). Dos casos de HSIL 39\% (34/87) estão compreendidos na faixa etária menor do que 30 anos, destes $19(55,9 \%)$ em mulheres com idade inferior a 24 anos. A Tabela 1 apresenta a distribuição dos resultados citológicos das 15.945 amostras por faixa etária. 
Tabela 1- Distribuição dos resultados citológicos por faixa etária.

\begin{tabular}{ccccccccc}
\hline $\begin{array}{c}\text { Faixa } \\
\text { etária }\end{array}$ & $\begin{array}{c}\text { NEGATIVA } \\
\mathbf{n}(\%)\end{array}$ & $\begin{array}{c}\text { ASC-US } \\
\mathbf{n}(\%)\end{array}$ & $\begin{array}{c}\text { ASC-H } \\
\mathbf{n}(\%)\end{array}$ & $\begin{array}{c}\text { LSIL } \\
\mathbf{n}(\%)\end{array}$ & $\begin{array}{c}\text { HSIL } \\
\mathbf{n}(\%)\end{array}$ & $\begin{array}{c}\text { CEC } \\
\mathbf{n}(\%)\end{array}$ & $\begin{array}{c}\text { AGC } \\
\mathbf{n}(\%)\end{array}$ & $\begin{array}{c}\text { Total } \\
\mathbf{n}(\%)\end{array}$ \\
\hline Até $\mathbf{2 4}$ & $1818(86,4)$ & $93(4,4)$ & $24(1,1)$ & $150(7,1)$ & $19(0,9)$ & $0(0)$ & $0(0)$ & $2104(13,2)$ \\
$\mathbf{2 5 - 2 9}$ & $1454(90,8)$ & $65(4,4)$ & $14(0,9)$ & $53(3,3)$ & $15(0,9)$ & $0(0)$ & $1(<0,1)$ & $1602(10,0)$ \\
$\mathbf{3 0 - 3 4}$ & $1703(91,3)$ & $83(4,5)$ & $12(0,6)$ & $55(2.9)$ & $12(0,6)$ & $0(0)$ & $0(0)$ & $1865(11,7)$ \\
$\mathbf{3 5 - 3 9}$ & $1697(94,0)$ & $49(2,7)$ & $15(0,8)$ & $35(1.9)$ & $9(0,5)$ & $0(0)$ & $1(<0,1)$ & $1806(11,3)$ \\
$\mathbf{4 0 - 4 4}$ & $1626(93,1)$ & $59(3,4)$ & $13(0,7)$ & $33(1,9)$ & $13(0,7)$ & $1(<0,1)$ & $1(<0,1)$ & $1746(11,0)$ \\
$\mathbf{4 5 - 4 9}$ & $1622(94,3$ & $61(3,5)$ & $9(0,5)$ & $23(1,3)$ & $4(0,2)$ & $1(<0,1)$ & $0(0)$ & $1720(10,8)$ \\
$\mathbf{5 0 - 5 4}$ & $1508(94,5)$ & $47(2,9)$ & $13(0,8)$ & $19(1,2)$ & $8(0,5)$ & $0(0)$ & $1(<0,1)$ & $1596(10,0)$ \\
$\mathbf{5 5 - 5 9}$ & $1227(95,7)$ & $31(2,4)$ & $9(0,7)$ & $12(0,9)$ & $2(0,2)$ & $0(0)$ & $1(<0,1)$ & $1282(8,0)$ \\
$\mathbf{6 0 - 6 4}$ & $973(96,0)$ & $25(2,5)$ & $5(0,5)$ & $7(0,7)$ & $3(0,3)$ & $0(0)$ & $1(<0,1)$ & $1014(6.4)$ \\
$\mathbf{6 5 +}$ & $1165(96,3)$ & $33(2,7)$ & $5(0,4)$ & $5(0,4)$ & $2(0,2)$ & $0(0)$ & $0(0)$ & $1210(7.6)$ \\
\hline Total & $\mathbf{1 4 7 9 3 ( 9 2 , 8 )}$ & $\mathbf{5 4 6 ( 3 , 4 \% )}$ & $\mathbf{1 1 9 ( 0 , 7 )}$ & $\mathbf{3 9 2 ( 2 , 5 )}$ & $\mathbf{8 7}(\mathbf{0}, \mathbf{5})$ & $\mathbf{2 ( < 0 , 1 )}$ & $\mathbf{6 ( < 0 , 1 )}$ & $\mathbf{1 5 . 9 4 5}$ \\
\hline
\end{tabular}

Legenda: ASC- US: Células escamosas atípicas de significado indeterminado, ASC-H: Células escamosas atípicas, não podendo excluir lesão de alto grau; LSIL: Lesão intraepitelial escamosa de baixo grau; HSIL: Lesão intraepitelial escamosa de alto grau; CEC: Carcinoma epidermóide invasor; AGC: Atipia glandular de significado indeterminado.

\section{$5.4 \quad$ Teste de HrHPV}

Entre as 15.991 amostras analisadas, $100 \%$ apresentaram a presença do gene da beta globina humana, utilizado como controle interno para avaliação da qualidade das amostras. Nos casos em que no primeiro momento o controle interno apresentou falha, as amostras foram novamente homogeneizadas e processadas, desta forma apresentando resultados válidos. O teste molecular para a pesquisa do HPV, mostrou 15,0\% (2.398/15.991) das amostras positivas. Destas, infecções simples foram observadas em $1.756(73,3 \%)$ amostras, enquanto as amostras com dois ou mais tipos de HPVs representaram $(26,7 \%)$ casos.

Quando analisamos a presença do HPV em relação a citologia, excluindo as insatisfatórias, o DNA do vírus foi detectado em 12.1\% (1.790/15.945) das citologias classificadas como negativas, em 87,4\% (76/87) dos casos de HSIL e em 100\% (2/2) 
das amostras classificadas como carcinoma epidermóide invasor. A detecção do DNA do HPV aumenta de acordo com o grau de severidade das alterações citológicas conforme apresentado na Tabela 2.

Tabela 2- Distribuição dos resultados das 15.945 amostras para o DNA do HPV segundo a classificação na citologia oncótica.

\begin{tabular}{cccc}
\hline CITOLOGIA & \multicolumn{3}{c}{ HPV $\mathbf{n}(\%)$} \\
\hline NEGATIVO & $13.003(87,9)$ & $1.790(12,1)$ & $14.793(92,8 \%)$ \\
ASC-US & $376(68,9)$ & $170(31,1)$ & $546(3,4)$ \\
ASC-H & $49(41,2)$ & $70(58,8)$ & $119(0,7)$ \\
LSIL & $105(26,8)$ & $287(73,2)$ & $392(2,5)$ \\
HSIL & $11(12,6)$ & $76(87,4)$ & $87(0,5)$ \\
CEC & $0(-)$ & $2(100)$ & $2(<0,1)$ \\
AGC & $5(83,3)$ & $1(16,7)$ & $6(<0,1)$ \\
TOTAL & $\mathbf{1 3 . 5 4 9 ( 8 5 , 0 )}$ & $\mathbf{2 . 3 9 6 ( 1 5 , 0 )}$ & $\mathbf{1 5 . 9 4 5 ( 1 0 0 , 0 )}$ \\
\hline
\end{tabular}

Legenda: ASC- US: Células escamosas atípicas de significado indeterminado, ASC-H: Células escamosas atípicas, não podendo excluir lesão de alto grau; LSIL: Lesão intraepitelial escamosa de baixo grau; HSIL: Lesão intraepitelial escamosa de alto grau; CEC: Carcinoma epidermóide invasor; AGC: Atipia glandular de significado indeterminado

Os tipos de HPVs mais frequentes foram representados pelos grupos P3 em 600 amostras (3,8\%) seguidos do grupo P2 em 583 (3,6\%). Quando analisados individualmente, os HPVs 16 e 52 representaram 504 (3,2\%) e 391 (2,4\%) amostras respectivamente. O Gráfico 4 apresenta os resultados obtidos pelo ensaio BD Onclarity ${ }^{\circledR}$ (BD Diagnostics - TriPath, Burlington, NC, EUA). 
Gráfico 4- Frequência dos tipos de HPVs identificados em 15.991 amostras. Legenda: P1: HPV 33/58; P2: HPV 56/59/66; P3: HPV 35, 39 e 68.

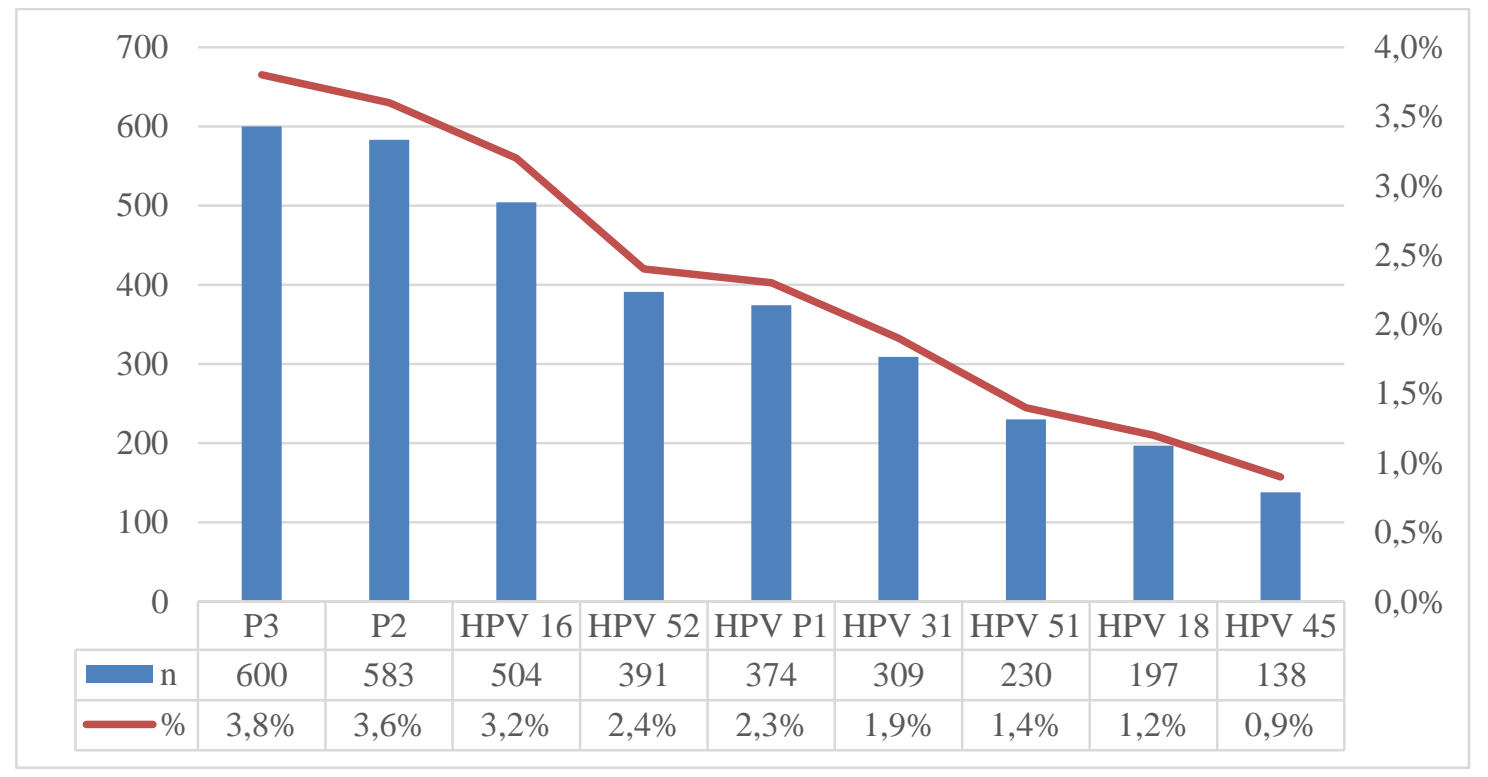

Quando estratificados por faixa etária, os resultados do teste molecular mostram um decréscimo na detecção do DNA do HPV com o aumento da idade 40,7\% $(860 / 2.112)$ de positividade na faixa etária < ou = a 24 anos; 21,5\% (345/1.607) na faixa etária 25 a 29 anos; 17,4\% (325/1.870) de 30 a 34 anos; 6,5\% (66/1.017) para as mulheres de 60 a 64 anos, enquanto que para o grupo etário com 65 anos ou mais 5,4\% (66/1.213) das amostras, conforme apresentado no Gráfico 5 também para demais grupos etários. 
Gráfico 5- Presença do DNA do HPV estratificados por faixa etária em 15.991 mulheres analisadas no estudo.

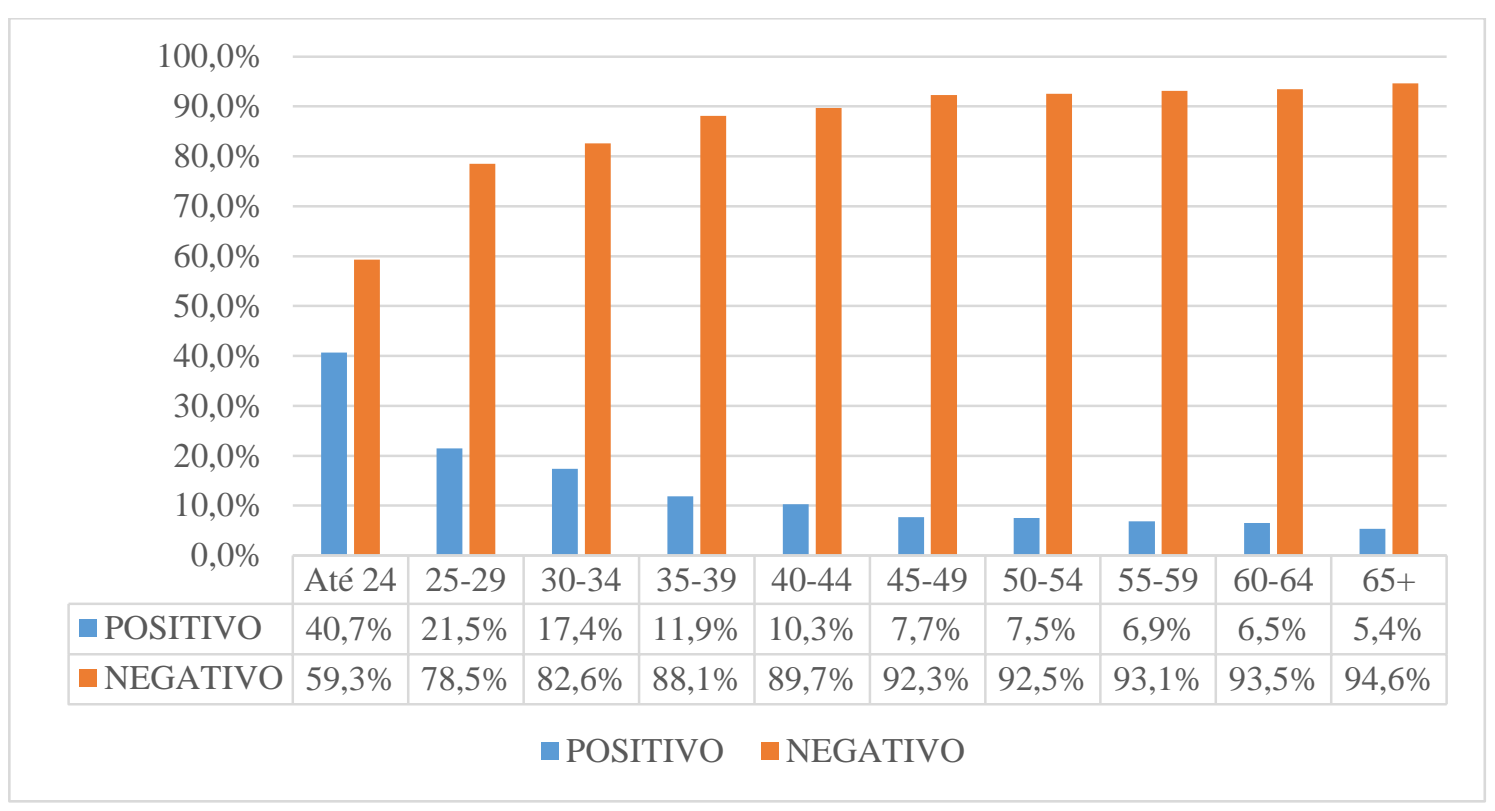

Em relação as frequências dos HPVs de acordo com as faixas etárias, o HPV P2 foi o mais frequente $11,7 \%(246 / 2.112)$ nas mulheres com idade inferior ou igual a $24 \operatorname{anos}(<$ ou = a 24 anos $)$, como também nos grupos etários de 50-54 (2,2\%; 35/1.599) e 60-64 anos $(2,3 \% ; 23 / 1.017)$, enquanto que os HPVs P3 apresentaram maior frequência nas demais faixas etárias, sendo que a faixa etária compreendida entre 55 a 59 anos demonstrou uma frequência equivalente $(1,5 \%)$ para os HPVs P2, P3 e P1. Seguindo a distribuição genotípica geral do HPV, o genótipo 16, o tipo viral isolado mais frequente foi detectado em $10,4 \%$ da faixa etária com idade inferior ou igual a 24 $\operatorname{anos}(<$ ou $=$ a 24 anos $)$ e equivalente ao HPV P3 no grupo etário de 30 a 34 anos, 4,1\% versus 4,2\% respectivamente. A frequência dos diferentes tipos de HPVs de acordo com os grupos etários é apresentada no Gráfico 6. 
Gráfico 6- Distribuição dos genótipos de HPV de acordo com as faixas etárias.

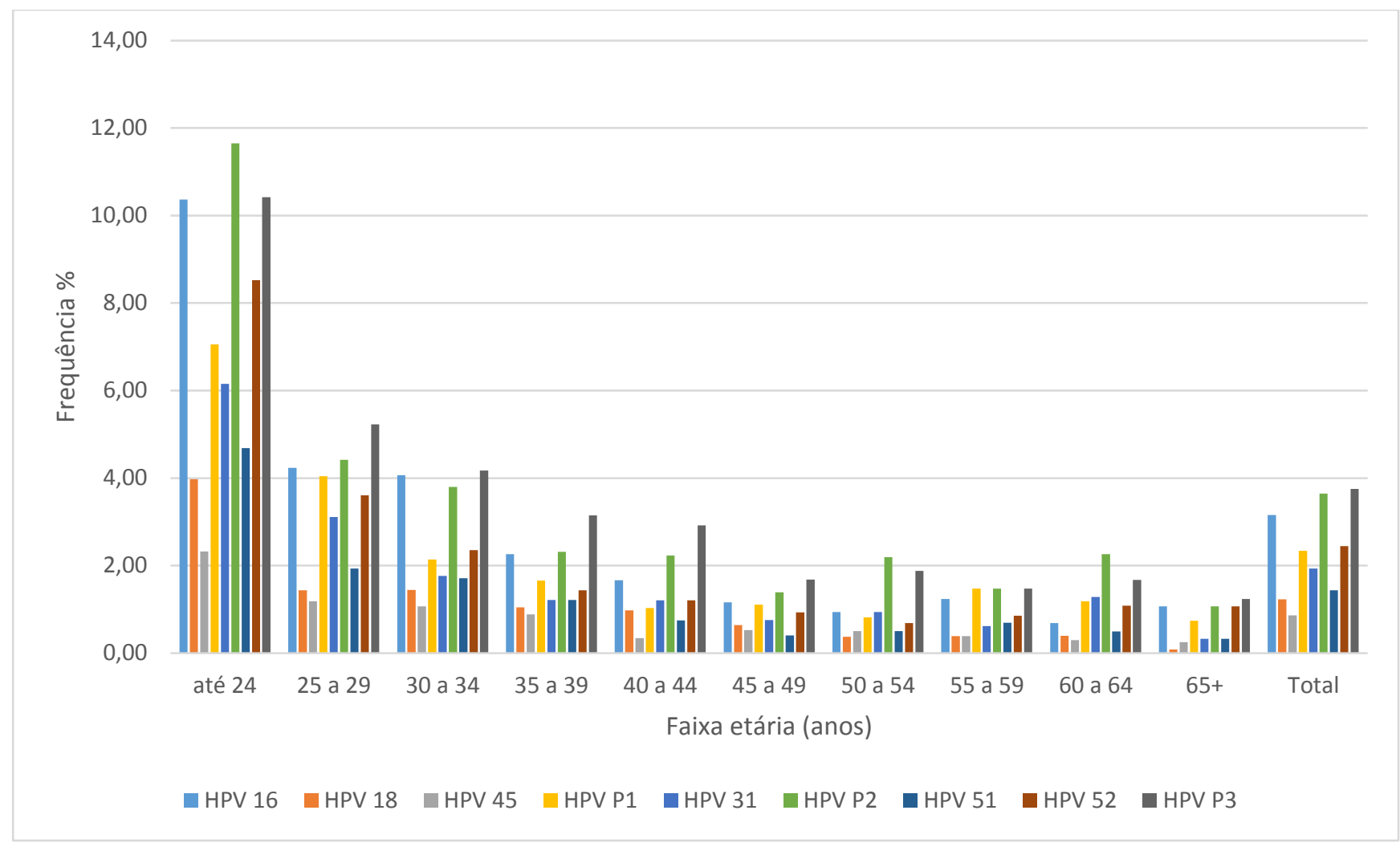

\subsection{Tipos de HPV e citologia oncótica}

Os resultados dos genótipos dos HPVs 16 e 18 foram analisados individualmente ou combinados, genótipos 16 e/ou 18. Genótipo 16 incluiu todos os casos positivos isoladamente para o HPV 16 com ou sem a presença dos demais HrHPVs, mas sem o HPV 18. Genótipo 18 incluiu todos resultados positivos para HPV 18 isolados com ou sem a presença dos demais HrHPVs e negativos para o HPV 16, enquanto as outras amostras foram positivas apenas para os demais HrHPVs, não 16 e 18. 
O HPV 16 foi detectado em 28,7\% (25/87) das amostras classificadas como HSIL, o HPV 18 em 5,0\% (5/87) e em um dos casos (50\%) classificados como carcinoma epidermóide invasor; os demais tipos de HPVs incluídos no teste, denominados aqui como outros HrHPVs (não 16 e 18) totalizaram 52,9\% (46/87) dessas amostras, enquanto 12,6\% (11/87) dos casos de HSIL foram HPV negativos, e nos casos de LSIL, o HPV 16 representou 20,9\% (82/392). Nas citologias classificadas como negativas, $12,1 \%(1.790 / 14.793)$ mostraram-se positivas para a presença do DNA viral, destas 9,1\% (1.396/14.793) foram compostas pelos HrHPVs (HPVs não 16/18), enquanto que para os casos de atipias glandulares (AGC) 83,3\% (5/6) apresentaram resultado negativo para o DNA do HPV. O HPV 31, aqui incluído no grupo dos HPVs de alto risco não 16 e 18, foi detectado no segundo caso de carcinoma epidermóide invasor de nossa casuística, paciente essa que veio a óbito durante o período deste estudo. A distribuição dos tipos de HPV de acordo com o diagnóstico citológico estratificando os genótipos 16 e 18 e os demais agrupados são demonstradas no Gráfico 7. 
Gráfico 7- Distribuição dos tipos de HPV de acordo com a classificação citológica em 15.945 amostras.

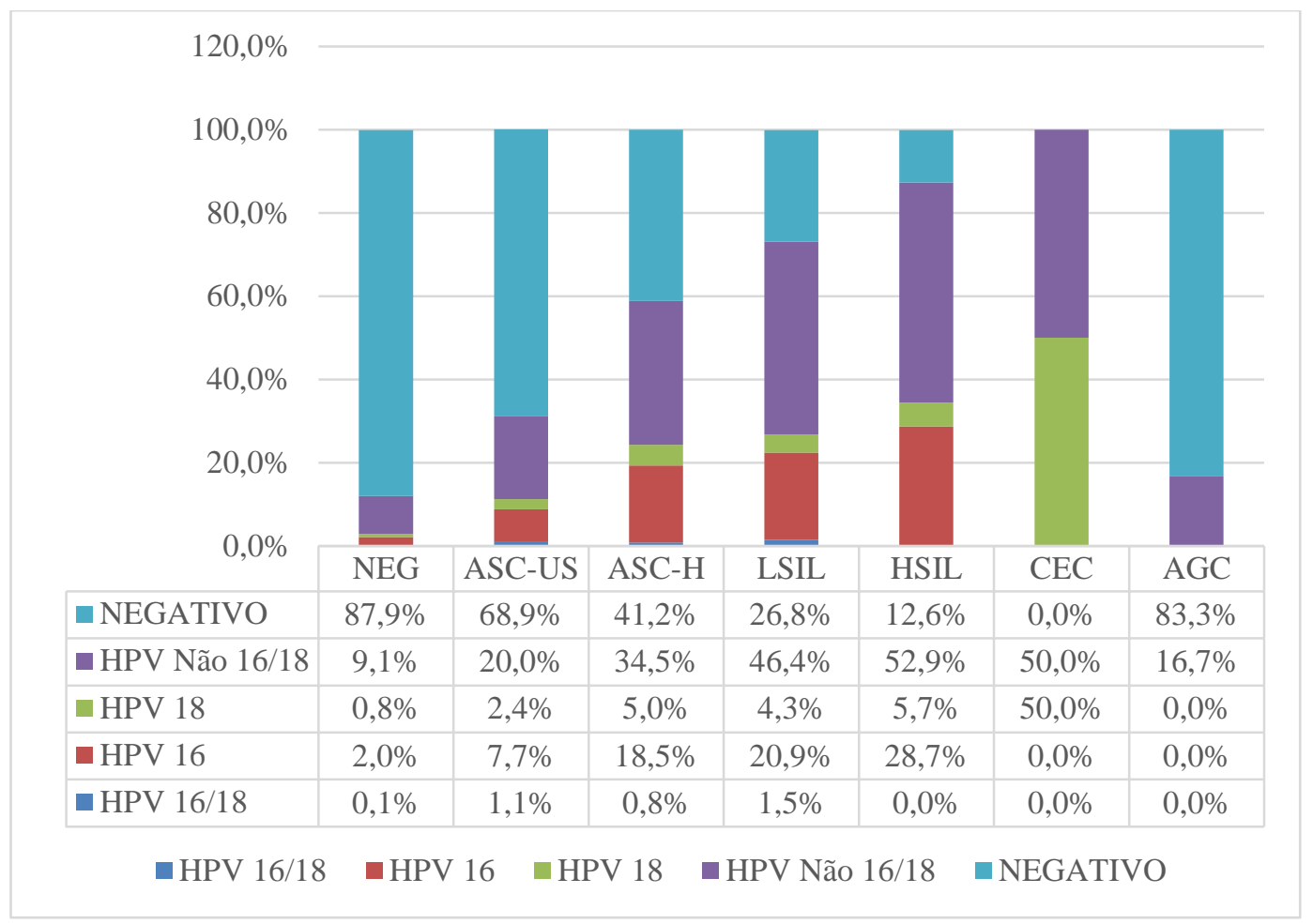

Legenda: NEG: Negativa, ASC- US: Células escamosas atípicas de significado indeterminado, ASC-H: Células escamosas atípicas, não podendo excluir lesão de alto grau; LSIL: Lesão intraepitelial escamosa de baixo grau; HSIL: Lesão intraepitelial escamosa de alto grau; CEC: Carcinoma epidermóide invasor; AGC: Atipia glandular de significado indeterminado

\subsection{Focal point e distribuição das infecções simples e coinfecção pelo HPV}

O Focalpoint classificou os dois casos de carcinoma no quintil 1 (Q1) e aproximadamente $90 \%$ dos casos de HSIL e $80 \%$ das citologias classificadas como ASC-H nos Q1 e Q2 respectivamente, enquanto o Q5 teve seu maior percentual para as citologias negativas $(21,8 \%)$. Aproximadamente $8 \%$ (1.247) das amostras não foram passíveis de análise pelo Focalpoint, devido principalmente a fissuras nas lamínulas ou 
presença de bolhas. A distribuição dos resultados do Focalpoint de acordo com a classificação citológica por leitura manual é mostrada no Gráfico 8.

Gráfico 8- Distribuição das classes citológicas de acordo com os quintis do Focalpoint.

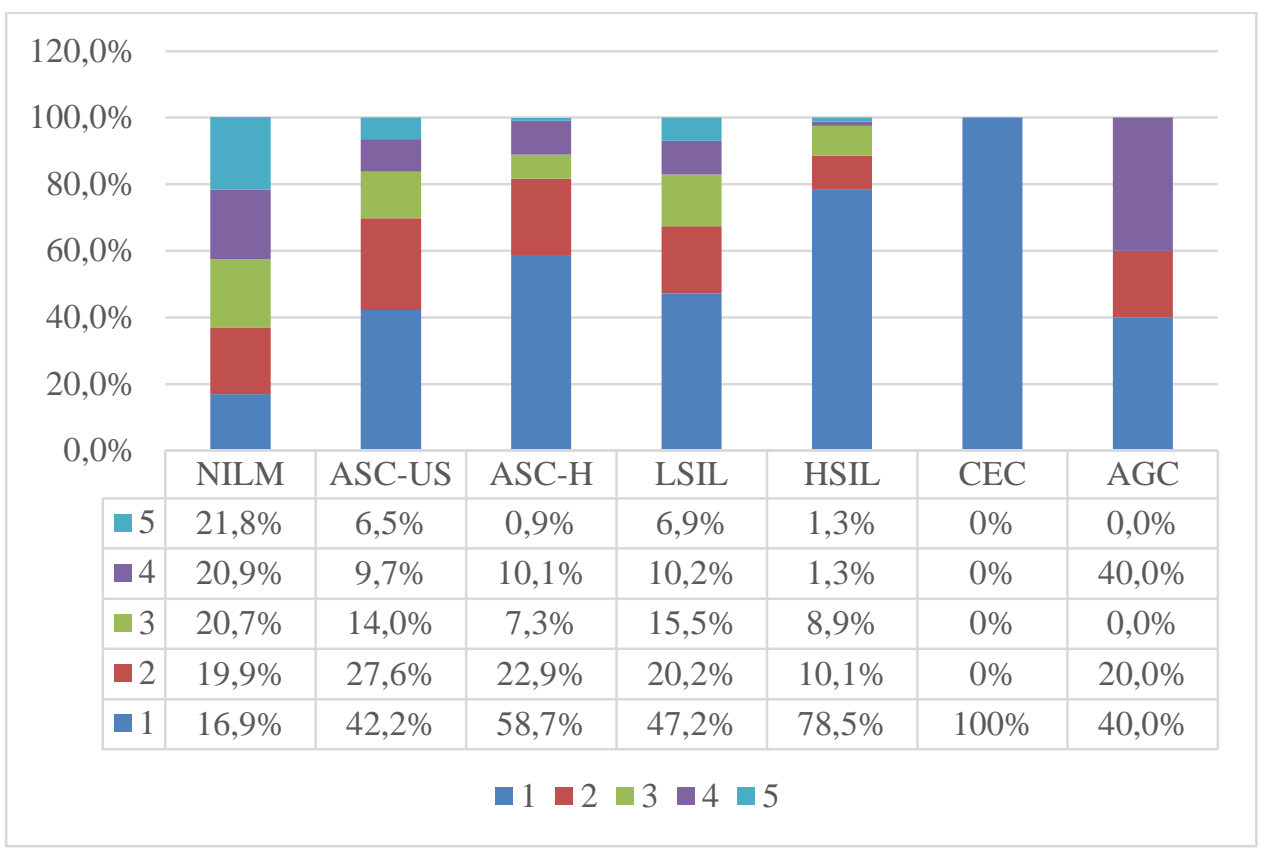

Legenda: ASC- US: Células escamosas atípicas de significado indeterminado, ASC-H: Células escamosas atípicas, não podendo excluir lesão de alto grau; LSIL: Lesão intraepitelial escamosa de baixo grau; HSIL: Lesão intraepitelial escamosa de alto grau; CEC: Carcinoma epidermóide invasor; AGC: Atipia glandular de significado indeterminado. Quintis Focalpoint representados pelos números 1 a 5 .

Ao analisar a distribuição das infecções simples e coinfecção por 2 ou mais tipos de HPV de acordo com a classificação citológica, uma única citologia, classificada como negativa, teve a presença de todos os tipos virais. A infecção simples foi observada nas citologias identificadas como HSIL em 49 (56,3\%) amostras como também nos dois casos (100\%) de CEC; coinfecção por dois ou mais tipos virais foram mais frequentes nos casos de HSIL e LSIL, respectivamente em 31\% e 30,1\%. Esses dados são demonstrados na Tabela 3. 
Tabela 3- Número de tipos de HPV detectados segundo a classe citológica.

\begin{tabular}{cccccccccc}
\hline CITOLOGIA & $\begin{array}{c}\mathbf{0} \\
\mathbf{n}(\%)\end{array}$ & $\begin{array}{c}\mathbf{1} \\
\mathbf{n}(\%)\end{array}$ & $\begin{array}{c}\mathbf{2}(\%) \\
\mathbf{n}(\%)\end{array}$ & $\begin{array}{c}\mathbf{n}(\%) \\
\mathbf{n}(\%)\end{array}$ & $\begin{array}{c}\mathbf{5}(\%) \\
\mathbf{n}(\%)\end{array}$ & $\begin{array}{c}\mathbf{6} \\
\mathbf{n}(\%)\end{array}$ & $\begin{array}{c}\text { Total } \\
\mathbf{n}(\%)\end{array}$ \\
\hline NEGATIVA & $13.003(87,9)$ & $1.377(9,3)$ & $298(2,0)$ & $78(0,5)$ & $26(0,2)$ & $7(<0,1)$ & $3(<0,1)$ & $1(<0,1)$ & $14.793(92,8)$ \\
ASC-US & $376(68,9)$ & $109(20,0)$ & $41(7,5)$ & $13(2,4)$ & $5(0,9)$ & $2(0,4)$ & $0(0)$ & $0(0)$ & $546(3,4)$ \\
ASC-H & $49(41,2)$ & $49(41,2)$ & $14(11,8)$ & $2(1,7)$ & $4(3,4)$ & $1(0,8)$ & $0(0)$ & $0(0)$ & $119(0,7)$ \\
LSIL & $105(26,8)$ & $169(43,1)$ & $77(19,6)$ & $28(7,1)$ & $8(2,0)$ & $4(1,0)$ & $1(0,3)$ & $0(0)$ & $392(2,5)$ \\
HSIL & $11(12,6)$ & $49(56,3)$ & $18(20,7)$ & $5(5,7)$ & $3(3,4)$ & $1(1,1)$ & $0(0)$ & $0(0)$ & $87(0,5)$ \\
CEC & $0(0)$ & $2(100,0)$ & $0(0)$ & $0(0)$ & $0(0)$ & $0(0)$ & $0(0)$ & $0(0)$ & $2(<0,1)$ \\
AGC & $5(83,3)$ & $1(16,7)$ & $0(0)$ & $0(0)$ & $0(0)$ & $0(0)$ & $0(0)$ & $0(0)$ & $6(<0,1)$ \\
\hline TOTAL & $\mathbf{1 3 . 5 4 9 ( 8 5 , 0 )}$ & $\mathbf{1 . 7 5 6 ( 1 1 , 0 )}$ & $\mathbf{4 4 8 ( 2 , 8 )}$ & $\mathbf{1 2 6 ( 0 , 8 )}$ & $\mathbf{4 6 ( 0 , 3 )}$ & $\mathbf{1 5 ( 0 , 1 )}$ & $\mathbf{4}(<0, \mathbf{0})$ & $\mathbf{1}(<0, \mathbf{1})$ & $\mathbf{1 5 . 9 4 5}$
\end{tabular}

Legenda: ASC- US: Células escamosas atípicas de significado indeterminado, ASC-H: Células escamosas atípicas, não podendo excluir lesão de alto grau; LSIL: Lesão intraepitelial escamosa de baixo grau; HSIL: Lesão intraepitelial escamosa de alto grau; CEC: Carcinoma epidermóide invasor.

\subsection{HPV e escolaridade}

Ao avaliarmos a variável escolaridade, item presente no questionário padrão utilizado pelo SUS, $12.425(77,7 \%)$ mulheres souberam informar. Destas, as maiores frequências de positividade para o HPV foram observadas em mulheres que reportaram ter o segundo grau completo (721/4.247) e nível superior (179/1.050), ambas 17\%; enquanto mulheres com o primeiro grau incompleto, mulheres que não informaram a escolaridade e analfabetas totalizaram $8,9 \%$ (361/4.064), 18,3\% (652/3.566) e $6,3 \%$ (3/195) respectivamente das amostras com resultado positivo para HPV. Ao estratificarmos por faixa etária considerando somente as amostras HPV positivas com escolaridade informada $(n=1.746)$, as mulheres até 29 anos responderam por $47,8 \%$ da positividade. O Gráfico 9 demonstra a distribuição entre a escolaridade informada e a infecção pelo HPV. 
Gráfico 9- Distribuição dos grupos positivos e negativos para o HPV de acordo com a variável escolaridade.

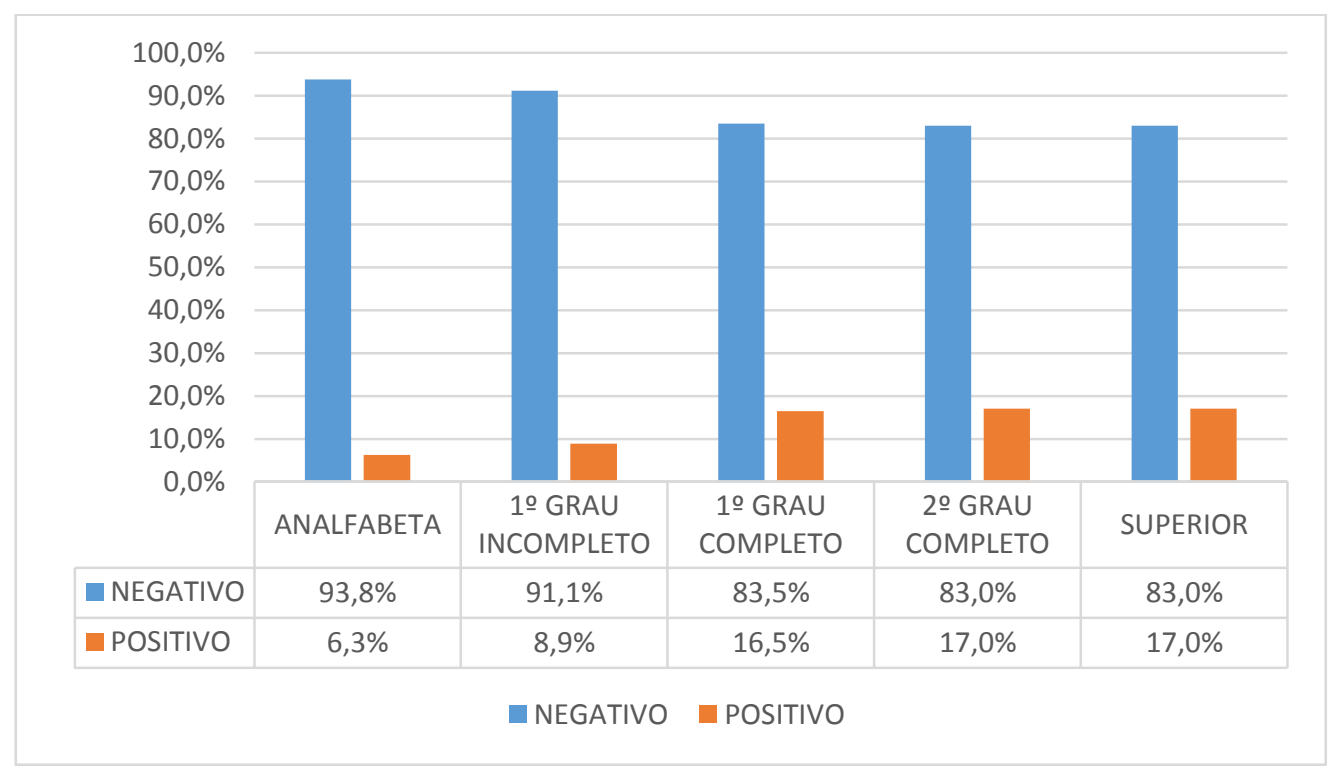

\subsection{HrHPV, citologia, colposcopia e biópsia}

De acordo com o protocolo proposto, $2.309(14,4 \%)$ das pacientes foram selecionadas para a colposcopia, e destas obtivemos os pareceres de $1.689(73,1 \%)$ como descrito a seguir neste item. Após serem encaminhados às UBSs, os resultados foram triados, e para as amostras com positividade apenas para os achados citológicos (ASC-US +), o seguimento foi baseado nas Diretrizes Brasileiras para o Rastreamento do Câncer do Colo do Útero (MS-Inca, 2011).

Desta forma, $1.287(55,7 \%)$ pacientes foram submetidas ao estudo colposcópico, enquanto 402 não realizaram a colposcopia, por apresentarem a primeira citologia alterada (ASC-US ou LSIL) quando o algoritmo brasileiro preconiza repetir o exame em 6 meses a 1 ano. Das amostras encaminhadas à colposcopia, 925 (71,9\%) foram consideradas normais, em $14(1,1 \%)$ o colo não foi visualizado, $6(0,5 \%)$ 
colposcopias foram insatisfatórias e oito $(0,6 \%)$ não tivemos retorno, enquanto que 334 (26,0\%) apresentaram alguma alteração e foram seguidas de biópsia, revelando 147 (44\%) resultados positivos distribuídos da seguinte forma: 75 (51\%) casos de NIC 1; 59 $(40,1 \%)$ de NIC 2; sete $(4,8 \%)$ de NIC 3; dois $(1,4 \%)$ de Carcinomas in situ; dois $(1,4 \%)$ de Carcinomas epidermóides invasivos e dois $(1,4 \%)$ de Adenocarcinomas. Os casos normais foram distribuídos entre cervicites, endocervicites, pólipos endocervicais, colpites e metaplasia escamosa sem atipias.

Quando estratificados por faixa etária, NIC 2+ foi detectada em 20,8\% (15/72) na faixa etária de 20 a 25 anos, em 15,3\% (11/72) em mulheres até 24 anos incluindo um Carcinoma in situ, enquanto as faixas compreendidas entre 40 e 54 anos incluíram os casos de carcinoma epidermóide invasor e adenocarcinomas, 56\% (42/75) dos casos de NIC 1 foram verificados em mulheres até 29 anos, apresentando taxa decrescente nos grupos etários de maior idade. Não foram identificadas lesões histológicas nas mulheres com 65 anos ou mais. A Tabela 4 apresenta os diagnósticos histológicos nos respectivos grupos etários. 
Tabela 4- Diagnóstico histológico de acordo com a faixa etária

\begin{tabular}{|c|c|c|c|c|c|c|c|c|c|c|c|c|c|c|c|}
\hline \multirow{2}{*}{$\begin{array}{l}\text { Faixa etária } \\
\text { (anos) }\end{array}$} & \multicolumn{2}{|c|}{ NEGATIVA } & \multicolumn{2}{|c|}{ NIC1 } & \multicolumn{2}{|c|}{ NIC2 } & \multicolumn{2}{|c|}{ NIC3 } & \multicolumn{2}{|c|}{ CIS } & \multicolumn{2}{|c|}{ CEC } & \multicolumn{2}{|c|}{$A D C$} & \multirow{2}{*}{$\begin{array}{l}\text { Total } \\
\text { Freq. }\end{array}$} \\
\hline & Freq. & $\% *$ & Freq. & $\% *$ & Freq. & \%* & Freq. & $\% *$ & Freq. & \%* & Freq. & $\% *$ & Freq. & $\% *$ & \\
\hline até 24 & 11 & 26,2 & 20 & 47,6 & 9 & 21,4 & 1 & 2,4 & 1 & 2,4 & 0 & 0,0 & 0 & 0,0 & 42 \\
\hline 25 a 29 & 43 & 53,8 & 22 & 27,5 & 14 & 17,5 & 1 & 1,3 & 0 & 0,0 & 0 & 0,0 & 0 & 0,0 & 80 \\
\hline 30 a 34 & 37 & 60,7 & 12 & 19,7 & 10 & 16,4 & 2 & 3,3 & 0 & 0,0 & 0 & 0,0 & 0 & 0,0 & 61 \\
\hline 35 a 39 & 29 & 60,4 & 8 & 16,7 & 10 & 20,8 & 1 & 2,1 & 0 & 0,0 & 0 & 0,0 & 0 & 0,0 & 48 \\
\hline 40 a 44 & 20 & 54,1 & 7 & 18,9 & 8 & 21,6 & 0 & 0,0 & 0 & 0,0 & 1 & 2,7 & 1 & 2,7 & 37 \\
\hline 45 a 49 & 18 & 69,2 & 3 & 11,5 & 3 & 11,5 & 0 & 0,0 & 1 & 3,8 & 1 & 3,8 & 0 & 0,0 & 26 \\
\hline 50 a 54 & 10 & 66,7 & 2 & 13,3 & 1 & 6,7 & 1 & 6,7 & 0 & 0,0 & 0 & 0,0 & 1 & 6,7 & 15 \\
\hline 55 a 59 & 10 & 83,3 & 0 & 0,0 & 2 & 16,7 & 0 & 0,0 & 0 & 0,0 & 0 & 0,0 & 0 & 0,0 & 12 \\
\hline 60 a 64 & 5 & 55,6 & 1 & 11,1 & 2 & 22,2 & 1 & 11,1 & 0 & 0,0 & 0 & 0,0 & 0 & 0,0 & 9 \\
\hline $65+$ & 4 & 100,0 & 0 & 0,0 & 0 & 0,0 & 0 & 0,0 & 0 & 0,0 & 0 & 0,0 & 0 & 0,0 & 4 \\
\hline Total & 187 & 56,0 & 75 & 22,5 & 59 & 17,7 & 7 & 2,1 & 2 & 0,6 & 2 & 0,6 & 2 & 0,6 & 334 \\
\hline
\end{tabular}

Legenda: NIC 1: Neoplasia Intraepitelial Cervical grau 1; NIC 2: Neoplasia Intraepitelial Cervical grau 2; NIC 3: Neoplasia Intraepitelial Cervical grau 3; CIS: Carcinoma in situ CEC: Carcinoma epidermóide invasor e ADC: Adenocarcinoma.*percentual calculado sobre cada faixa etária.

A distribuição dos tipos de HPV de acordo com o diagnóstico histológico estratificando os genótipos 16 e 18 e os demais HrHPvs agrupados é apresentada na Tabela 5. O HPV 16 foi detectado em 49,2\% (29/59) dos casos de NIC 2; 57,1\% (4/7) de NIC 3; em um dos casos de carcinoma in situ e nos dois casos de Adenocarcinoma, enquanto o HPV 18 teve seu maior percentual nos casos de NIC 2, presente em 8,5\% (5/59) dessas lesões, estando também presente em um dos casos de carcinoma epidermóide invasivo. Os demais HrHPVs foram identificados em 62,7\% (47/75) das lesões classificadas como NIC 1, em 40,7\% (24/59) dos casos NIC 2, em 42,9\% (3/7) de NIC 3 e em um caso de carcinoma in situ e carcinoma epidermóide invasor, nos quais foram identificados os genótipos 51 e 31 respectivamente, demonstrados a seguir. Dos 72 casos de NIC 2+, $71(98,6 \%)$ foram positivos para o ensaio de HrHPV; enquanto a citologia isolada classificou 18 destes casos como negativos. Cabe ressaltar 
que $100 \%$ casos de NIC $3+(n=13)$ foram positivos para o DNA do HPV. A Tabela 6 permite verificar a distribuição dos resultados do teste molecular, citológico, histológico, idade e intervalo entre os resultados citológicos/moleculares e realização da colposcopia das respectivas amostras NIC 2+ confirmadas histologicamente. Entre as amostras apresentando histologia NIC $1 \quad(\mathrm{~N}=75)$ a classificação citológica foi distribuída da seguinte forma: 38,3\% (28/75) eram citologias negativas; 9,3\% (7/75) eram ASC-US; 10,7\% (8/75) ASC-H; e LSIL e HSIL representando cada 21,3\% (16/75) dessas biópsias.

Tabela 5- Distribuição dos HPVs 16 e 18 e demais HrHPVs de acordo com a classificação histológica.

\begin{tabular}{|c|c|c|c|c|c|c|c|c|c|c|c|}
\hline \multirow[b]{3}{*}{ Biópsia } & \multirow{2}{*}{\multicolumn{2}{|c|}{ Negativo }} & \multirow{2}{*}{\multicolumn{2}{|c|}{ HPV 16 + 18}} & \multirow{2}{*}{\multicolumn{2}{|c|}{ HPV 16}} & \multirow{2}{*}{\multicolumn{2}{|c|}{ HPV 18}} & \multicolumn{2}{|c|}{ Outros } & \multirow[b]{2}{*}{ Total } \\
\hline & & & & & & & & & $\mathrm{HrH}$ & & \\
\hline & Freq. & $\%$ & Freq. & $\%$ & Freq. & $\%$ & Freq. & $\%$ & Freq. & $\%$ & Freq. \\
\hline NEGATIVA & 16 & 8,6 & 1 & 0,5 & 26 & 13,9 & 13 & 6,9 & 131 & 70,0 & 187 \\
\hline NIC1 & 2 & 2,7 & 3 & 4,0 & 20 & 26,7 & 3 & 4,0 & 47 & 62,7 & 75 \\
\hline NIC2 & 1 & 1,7 & 0 & 0,0 & 29 & 49,2 & 5 & 8,5 & 24 & 40,7 & 59 \\
\hline NIC3 & 0 & 0,0 & 0 & 0,0 & 4 & 57,1 & 0 & 0,0 & 3 & 42,9 & 7 \\
\hline CIS & 0 & 0,0 & 0 & 0,0 & 1 & 50,0 & 0 & 0,0 & 1 & 50,0 & 2 \\
\hline CEC & 0 & 0,0 & 0 & 0,0 & 0 & 0,0 & 1 & 50,0 & 1 & 50,0 & 2 \\
\hline ADC & 0 & 0,0 & 0 & 0,0 & 2 & 100,0 & 0 & 0,0 & 0 & 0,0 & 2 \\
\hline Total & 19 & 5,7 & 4 & 1,2 & 82 & 24,6 & 22 & 6,6 & 207 & 61,9 & 334 \\
\hline
\end{tabular}

Legenda: NIC 1: Neoplasia Intraepitelial Cervical grau 1; NIC 2: Neoplasia Intraepitelial Cervical grau 2; NIC 3: Neoplasia Intraepitelial Cervical grau 3; CIS: Carcinoma in situ; CEC Carcinoma epidermóide invasor e ADC: Adenocarcinoma. 
Tabela 6- Perfil das amostras NIC $2+$ observadas no estudo de acordo com os testes molecular e citológico

\begin{tabular}{|c|c|c|c|c|c|}
\hline HPV & Focalpoint & Citologia & Idade (anos) & Biópsia & $\begin{array}{l}\text { Tempo para a colposcopia } \\
\text { (meses) }\end{array}$ \\
\hline $16, P 1,31$ & 1 & Negativa & 25 & NIC 2 & 1,6 \\
\hline 31 & 1 & Negativa & 26 & NIC 2 & 3,7 \\
\hline 18 & 1 & Negativa & 33 & NIC 2 & 3,1 \\
\hline 16 & 1 & Negativa & 37 & NIC 2 & 0,9 \\
\hline P2 & 3 & Negativa & 47 & NIC 2 & 1,6 \\
\hline 16 & 3 & Negativa & 20 & NIC 2 & 3,9 \\
\hline P3 & 4 & Negativa & 28 & NIC 2 & 1,3 \\
\hline 16,31 & 4 & Negativa & 60 & NIC 2 & 2,0 \\
\hline 16 & 4 & Negativa & 35 & NIC 2 & 1,4 \\
\hline 16 & 4 & Negativa & 37 & NIC 2 & 1,5 \\
\hline 52 & 5 & Negativa & 33 & NIC 2 & 0,5 \\
\hline 51 & 5 & Negativa & 27 & NIC 2 & 2,3 \\
\hline 45 & 5 & Negativa & 39 & NIC 2 & 3,1 \\
\hline 18 & 5 & Negativa & 40 & NIC 2 & 3,0 \\
\hline 16 & 5 & Negativa & 36 & NIC 2 & 1,5 \\
\hline 16 & 5 & Negativa & 35 & NIC 2 & 3,5 \\
\hline $16, \mathrm{P} 2$ & 1 & ASC-US & 33 & NIC 2 & Não informada \\
\hline 16,45 & 1 & ASC-US & 40 & NIC 2 & 5,5 \\
\hline 16 & 1 & ASC-US & 21 & NIC 2 & Não informada \\
\hline P1 & 2 & ASC-US & 32 & NIC 2 & 1,6 \\
\hline 18 & NR & LSIL & 33 & NIC 2 & Não informada \\
\hline $18,45, \mathrm{P} 2,52, \mathrm{P} 3$ & 1 & LSIL & 23 & NIC 2 & 1,8 \\
\hline $16, P 1,51,52$ & 1 & LSIL & 22 & NIC 2 & 1,3 \\
\hline $\mathrm{P} 1,51$ & 1 & LSIL & 28 & NIC 2 & 3,1 \\
\hline $\mathrm{P} 1$ & 1 & LSIL & 22 & NIC 2 & 2,6 \\
\hline 16 & 1 & LSIL & 29 & NIC 2 & 2,0 \\
\hline 16 & 1 & LSIL & 59 & NIC 2 & 4,9 \\
\hline 16 & 1 & LSIL & 46 & NIC 2 & 1,2 \\
\hline $16, \mathrm{P} 1, \mathrm{P} 2$ & 2 & LSIL & 22 & NIC 2 & 0,5 \\
\hline 16 & 4 & LSIL & 33 & NIC 2 & 2,2 \\
\hline 52 & NR & ASC-H & 36 & NIC 2 & 1,3 \\
\hline P1 & NR & ASC-H & 35 & NIC 2 & 1,8 \\
\hline 16 & NR & ASC-H & 22 & NIC 2 & 2,3 \\
\hline $16, \mathrm{P} 1,31, \mathrm{P3}$ & 1 & ASC-H & 32 & NIC 2 & 6,6 \\
\hline P1 & 1 & ASC-H & 42 & NIC 2 & 1,5 \\
\hline 16 & 1 & ASC-H & 39 & NIC 2 & 1,2 \\
\hline 16 & 1 & ASC-H & 26 & NIC 2 & 0,6 \\
\hline $16, \mathrm{P} 1, \mathrm{P} 2, \mathrm{P3}$ & 2 & ASC-H & 27 & NIC 2 & 1,3 \\
\hline $31,52, \mathrm{P3}$ & 1 & HSIL & 63 & NIC 2 & 0,4 \\
\hline
\end{tabular}


Tabela 6- Perfil das amostras NIC $2+$ observadas no estudo de acordo com os testes molecular e citológico. (Continuação)

\begin{tabular}{|c|c|c|c|c|c|}
\hline HPV & Focalpoint & Citologia & Idade (anos) & Biópsia & $\begin{array}{c}\text { Tempo para a colposcopia } \\
\text { (meses) }\end{array}$ \\
\hline $45,51, P 3$ & 1 & $\mathrm{HSIL}$ & 27 & NIC 2 & 5,8 \\
\hline $16,31, P 2, P 3$ & 1 & HSIL & 31 & NIC 2 & 3,5 \\
\hline $\mathrm{P} 1, \mathrm{P} 2, \mathrm{P} 3$ & 1 & HSIL & 29 & NIC 2 & 3,1 \\
\hline$P 2,52$ & 1 & HSIL & 50 & NIC 2 & 0,7 \\
\hline 51 & 1 & HSIL & 27 & NIC 2 & 0,6 \\
\hline $31, \mathrm{P} 2$ & 1 & HSIL & 41 & NIC 2 & 1,0 \\
\hline 16,31 & 1 & HSIL & 23 & NIC 2 & 4,8 \\
\hline 31 & 1 & HSIL & 29 & NIC 2 & 3,5 \\
\hline 31 & 1 & HSIL & 44 & NIC 2 & 1,6 \\
\hline $18, \mathrm{P} 1$ & 1 & HSIL & 40 & NIC 2 & 2,2 \\
\hline $\mathrm{P} 1$ & 1 & HSIL & 59 & NIC 2 & 0,7 \\
\hline P1 & 1 & HSIL & 40 & NIC 2 & 1,0 \\
\hline P1 & 1 & HSIL & 27 & NIC 2 & 0,9 \\
\hline 16 & 1 & HSIL & 45 & NIC 2 & 4,2 \\
\hline 16 & 1 & HSIL & 41 & NIC 2 & 1,3 \\
\hline P3 & 2 & HSIL & 20 & NIC 2 & 2,8 \\
\hline 16,31 & 3 & HSIL & 34 & NIC 2 & 3,7 \\
\hline 16,31 & 3 & HSIL & 35 & NIC 2 & 0,1 \\
\hline Negativo & 3 & HSIL & 30 & NIC 2 & 5,0 \\
\hline 16 & 4 & HSIL & 29 & NIC 2 & 0,6 \\
\hline $16, \mathrm{P} 1$ & 1 & Negativa & 31 & NIC 3 & 1,4 \\
\hline $16, \mathrm{P} 1$ & 1 & ASC-US & 35 & NIC 3 & 5,7 \\
\hline $45, P 1$ & 5 & ASC-US & 23 & NIC 3 & 3,9 \\
\hline $\mathrm{P} 1$ & NR & HSIL & 62 & NIC 3 & 1,4 \\
\hline 16 & 1 & HSIL & 52 & NIC 3 & 7,7 \\
\hline 52 & 2 & HSIL & 28 & NIC 3 & 3,7 \\
\hline 16 & 2 & HSIL & 30 & NIC 3 & 1,2 \\
\hline 51 & 1 & ASC-H & 47 & Carcinoma in situ & 1,4 \\
\hline 16 & 2 & HSIL & 23 & $\begin{array}{c}\text { Carcinoma in situ } \\
\text { Carcinoma } \\
\text { epidermóide }\end{array}$ & 1,4 \\
\hline 31 & 1 & CEC & 42 & $\begin{array}{c}\text { invasor } \\
\text { Carcinoma } \\
\text { epidermóide }\end{array}$ & 5,3 \\
\hline 18 & 1 & CEC & 45 & invasor & 1,2 \\
\hline 16 & 5 & Negativa & 51 & Adenocarcinoma & 5,9 \\
\hline 16 & 4 & ASC-H & 43 & Adenocarcinoma & 2,4 \\
\hline
\end{tabular}

Legenda: FP (Focal Point) Q: os campos são classificados em 5 quintis, de 1 a 5 , de maior para menor chance de haver lesão (os quintis 1 e 2 são os que mais provavelmente apresentam lesões); NR: leitura não realizada; NIC: Neoplasia intraepitelial graus 1, 2 e 3. ASC- US: Células escamosas atípicas de significado indeterminado, ASC-H: Células escamosas atípicas, não podendo excluir lesão de alto grau; LSIL: Lesão intraepitelial escamosa de baixo grau; HSIL: Lesão intraepitelial escamosa de alto grau; CEC: Carcinoma epidermóide invasor. 
A razão de chances ou razão de possibilidades odds ratio (O.R.) e seus respectivos intervalos de confiança foram calculados para NIC $2+$ para as diferentes categorias de resultados do teste de HPV. Os resultados dos genótipos dos HPVs 16 e 18 foram analisados individualmente ou combinados, genótipos 16 e/ou 18. Genótipo 16 incluiu todos os casos positivos isoladamente para o HPV $16 \mathrm{com}$ ou sem a presença do HPV 18 e dos demais HrHPVs. Genótipo 18 incluiu todos resultados positivos para HPV 18 isolados com ou sem a presença dos demais HrHPVs e casos negativos para o HPV 16, enquanto que para os demais HrHPVs foram consideradas as amostras positivas apenas para os demais genótipos de alto risco, não 16 e 18. A Figura 7 apresenta as diferentes combinações de seleção das amostras.

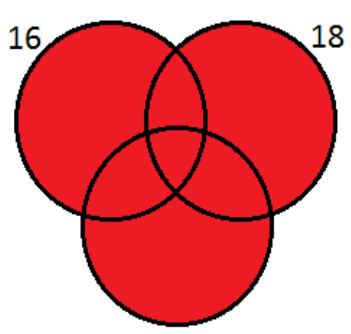

Outros HR

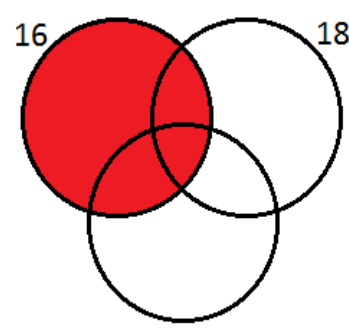

Outros HR

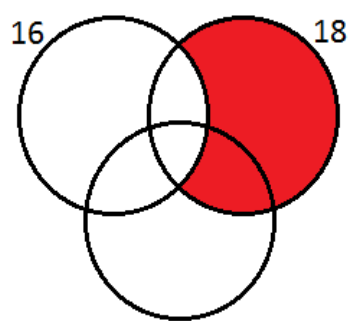

Outros HR

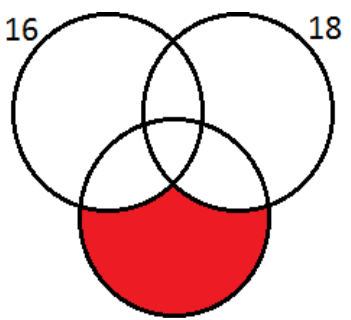

Outros HR

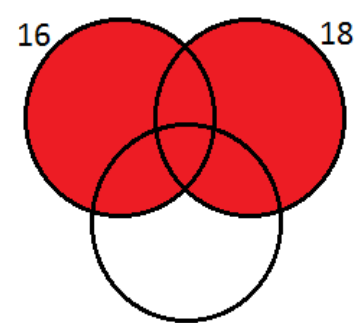

Outros HR

Figura 7- Esquema de seleção de amostras para o cálculo da razão de chances (odds ratio) de acordo com os genótipos 16, 18 e demais HrHPVs para os casos NIC 2+. Legenda: 16 = HPV 16; 18 = HPV 18; Outros HR = demais genótipos de HrHPV incluídos no ensaio BD Onclarity®. 
A presença do HPV 16 foi associado com um grande aumento no risco para NIC 2+, com uma odds ratio de 1.045, seguida da combinação HPV 16/18 OR=906, enquanto que na presença dos demais HrHPVs a razão de chances foi de 232 vezes em relação às mulheres com resultado do DNA do HPV negativo. A Tabela 7 permite verificar as razões de chances e os intervalos de confiança para diagnóstico de NIC 2+ de acordo com os genótipos virais.

Tabela 7- Estimativas das razões de chances para Lesões de Alto Grau de acordo com o resultado do teste de HPV.

\begin{tabular}{lcccc}
\hline & \multicolumn{4}{c}{ NIC 2+ } \\
Resultado do teste de HPV & OR & IC de 95\% & p \\
\hline HrHPV+ vs HPV- & 414,7 & 57,6 & $2.986,3$ & $<0,001$ \\
HPV-16+ vs HPV- & $1.045,5$ & 143,0 & $7.642,1$ & $<0,001$ \\
HPV-18+ vs HPV- & 503,4 & 60,3 & $4.205,1$ & $<0,001$ \\
Outros HrHPV+ vs HPV- & 232,3 & 31,6 & $1.706,2$ & $<0,001$ \\
HPV-16+/HPV-18+ vs HPV- & 906,1 & 124,5 & $6.594,3$ & $<0,001$ \\
HPV-16+ vs outros HrHPV+ & 4,5 & 2,7 & 7,4 & $<0,001$ \\
\end{tabular}

Legenda: OR: odds ratio; HrHPV+ inclui HPV 16+ e/ou HPV18+ e/ou outros HrHPV; HPV 16+ inclui HPV 16+ com ou sem HPV 18+, e com ou sem os outros HrHPV; HPV 18+ inclui HPV 16 (-) e HPV 18 +, com ou sem os outros HrHPV+; outros HrHPV+ inclui HPV 16 (-), HPV 18(-) com os 12 outros HrHPV+; HPV 16+/HPV 18+ inclui HPV 16+ e/ou HPV18+ com ou sem os outros HrHPVs. 


\subsection{Comparação de estratégias (algoritmos) de rastreio e triagem tendo como desfecho os casos NIC 2+}

A estratégia de rastreio mais sensível foi aquela utilizando o teste de HPV isolado (estratégia 1), com encaminhamento de todas mulheres HPV positivas para a colposcopia, detectando 98,6\% (71/72) dos casos de NIC 2+. Entretanto, é uma estratégia com a maior demanda para o exame colposcópico, requerendo 33,8 colposcopias para detectar um caso de NIC 2+, com especificidade de $85,4 \%$, inferior as demais abordagens associadas à citologia. A estratégia 2 (citologia isolada), com o encaminhamento de todos os casos ASC-US+ para colposcopia mostrou sensibilidade de $75 \%$, uma inferioridade de $23,6 \%$ em relação à estratégia 1.

Utilizando a combinação da citologia com o teste de HPV (coteste), a estratégia 3 direciona para a colposcopia mulheres com ambos testes positivos e os casos citológicos > ASC-US independente do resultado do HPV, apresentou a mesma sensibilidade do rastreio citológico (75\%), com ligeiro aumento na especificidade 95,5\% vs 93,1 e redução do número de colposcopias em 32,6\% (776 vs 1.152) quando comparada à citologia isolada, no entanto com grande demanda dos testes de HPV, dobrando o número de testes totais realizados, uma característica negativa do coteste. Ainda baseada na citologia, a estratégia 4, esta com uso estabelecido na prática clínica, utilizou a citologia com método inicial e o teste de HPV como reflexo para os casos ASC-US, e referiu as citologias > ASC-US para a colposcopia, obtendo resultados similares à estratégia 3 (coteste), no entanto deixando de realizar 15.399 testes de HPV, e com menor número de colposcopias requeridas 14,4 vs 21,3 do que a estratégia citológica isolada. A estratégia 5, a qual utilizou o teste de HPV 
como rastreio primário reservando a citologia para os casos positivos e colposcopia quando indicada mostrou baixa sensibilidade $73,6 \%$, requerendo 11,4 colposcopias para detectar um caso de NIC 2+, no entanto superior a estratégia 6 que estratificou os genótipos 16 e 18 direcionando diretamente para a colposcopia os casos positivos apenas para estes genótipos. Esta estratégia teve uma sensibilidade de 58,3\%, com aproximadamente quatro vezes menos colposcopias realizadas (672 vs 2.398) quando comparada à estratégia 1 (HPV isolado).

A estratégia 7 também iniciando com teste de HPV e genotipagem 16/18 adicionou a citologia como método de triagem para os demais HrHPVs seguida de colposcopia para os casos com diagnóstico $>$ ou = ASC-US, reduziu o número de casos em seguimento da estratégia 6 e aumentou em 31,9\% a sensibilidade (90,2\%), sendo necessárias praticamente a mesma quantidade de colposcopias requeridas $(16,2)$ para detectar um caso de NIC 2+. Seguindo o mesmo princípio da genotipagem, mas com o corte nas citologias > ASC-US para os demais HrHPVs, a estratégia 8 apresentou sensibilidade de $87,5 \%$, perdendo dois casos de NIC $2+$ em relação à estratégia 7. Com o intuito de contemplar o que é preconizado pelas Diretrizes Brasileiras para o Rastreamento do Câncer do Colo do Útero (MS-Inca, 2011), encaminhando para a colposcopia mulheres com citologia ASC-H, AGC e HSIL ou lesão mais grave, a estratégia 9 apresentou sensibilidade de 52,8\% (34/72), 45,8\% mais baixa que a estratégia de rastreio primário baseado no teste de HPV (estratégia 1), sendo necessárias 5,6 colposcopias para detectar cada NIC 2+, especificidade de $98,9 \%$ e valores preditivos negativo e positivo de $99,8 \%$ e $17,8 \%$ respectivamente. Estratégia semelhante, a 10 incluiu somente as mulheres com a faixa etária de 25 a 64 anos, detectando 34 casos de NIC 2+ em uma população de 12.631 mulheres, perdendo 4 casos em relação à estratégia 9 se considerássemos as 15.991 mulheres. 
Se adotássemos a política de alguns países desenvolvidos que utilizam o algoritmo de rastreio com teste molecular para HrHPV para mulheres com $\geq 30$ anos, nossa taxa de encaminhamento para a colposcopia seria de 7,5\% (1.193/15.991) considerando as mulheres HPV positivas, e de 1,9\% (298/15.991) mulheres se levarmos em conta apenas os genótipos 16 e 18. Cabe ressaltar, conforme demonstrado na Tabela 6, que não teriam sido detectadas 10/72 (14\%) lesões NIC 2+ histologicamente confirmadas nesta faixa etária.

A Tabela 8 demonstra as performances de cada estratégia para os casos NIC 2+. Os achados de sensibilidade e número de colposcopias requeridas por cada estratégia também são representados no Gráfico 10 e Tabela 9 de maneira resumida. As Figuras 8 a 18 representam de forma esquemática as diferentes estratégias de rastreio adotadas para os casos de NIC 2+, e números de casos potencialmente detectados e não detectados (seta em amarelo) de acordo com cada algoritmo. 
Tabela 8- $\quad$ Resultados das diferentes estratégias para a detecção de NIC 2+

\begin{tabular}{|c|c|c|c|c|c|c|c|c|c|c|c|c|c|c|}
\hline \multirow{2}{*}{\multicolumn{2}{|c|}{ Estratégias }} & \multirow{2}{*}{$\begin{array}{l}\text { № de } \\
\text { citologias } \\
\text { realizadas }\end{array}$} & \multirow{2}{*}{$\begin{array}{l}\text { № de } \\
\text { testes de } \\
\text { HPV } \\
\text { realizados }\end{array}$} & \multirow{2}{*}{$\begin{array}{l}\text { No de } \\
\text { colposcopias } \\
\text { realizadas }\end{array}$} & \multirow{2}{*}{$\begin{array}{c}\text { № de } \\
\text { colposcopias } \\
\text { para detectar } 1 \\
\text { caso de NIC2+ }\end{array}$} & \multirow{2}{*}{$\begin{array}{c}\text { № de casos de } \\
\text { NIC2+ } \\
\text { identificados }\end{array}$} & \multicolumn{2}{|c|}{ Sensibilidade (NIC2+) } & \multicolumn{2}{|c|}{$\begin{array}{l}\text { Especificidade } \\
\text { (NIC2+) }\end{array}$} & \multicolumn{2}{|c|}{ VPN (NIC2+) } & \multicolumn{2}{|c|}{ VPP (NIC2+) } \\
\hline & & & & & & & & IC de $95 \%$ & & IC de $95 \%$ & & IC de $95 \%$ & & IC de $95 \%$ \\
\hline 1 & HPV & 0 & 15.991 & 2.398 & 33,8 & 71 & 98,6 & $95,9-100,0$ & 85,4 & $84,8-85,9$ & 100,0 & $100,0-100,0$ & 3,0 & $2,3-3,6$ \\
\hline 2 & Citologia & 15.945 & 0 & 1.152 & 21,3 & 54 & 75,0 & $65,0-85,0$ & 93,1 & $92,7-93,5$ & 99,9 & $99,8-99,9$ & 4,7 & $3,5-5,9$ \\
\hline 3 & $\begin{array}{c}\text { Coteste corte em } \\
\text { ASC-US }\end{array}$ & 15.945 & 15.945 & 776 & 14,4 & 54 & 75,0 & $65,0-85,0$ & 95,5 & $95,1-95,8$ & 99,9 & $99,8-99,9$ & 7,0 & $5,2-8,7$ \\
\hline 4 & $\begin{array}{l}\text { Cito ASC-US seguida } \\
\text { HPV reflexo }\end{array}$ & 15.945 & 546 & 776 & 14,4 & 54 & 75,0 & $65,0-85,0$ & 95,5 & $95,1-95,8$ & 99,9 & $99,8-99,9$ & 7,0 & $5,2-8,7$ \\
\hline 5 & $\mathrm{HPV}+\rightarrow$ Cito & 2.396 & 15.991 & 606 & 11,4 & 53 & 73,6 & $63,4-83,8$ & 96,5 & $96,2-96,8$ & 99,9 & $99,8-99,9$ & 8,7 & $6,5-11,0$ \\
\hline 6 & $\begin{array}{l}\text { HPV com genotipagem } \\
16 \text { e } 18 \\
\text { Genotipagem } 16 \text { e } 18+\end{array}$ & 0 & 15.991 & 672 & 16,0 & 42 & 58,3 & $46,9-69,7$ & 96,0 & $95,7-96,3$ & 99,8 & $99,7-99,9$ & 6,3 & $4,4-8,1$ \\
\hline 7 & $\begin{array}{c}\text { HrHPV } \rightarrow \text { Cito, } \\
\text { corte em } \geq \text { ASC-US } \\
\text { Genotipagem } 16 \text { e } 18+\end{array}$ & 1.726 & 15.991 & 1.052 & 16,2 & 65 & 90,3 & $83,4-97,1$ & 93,8 & $93,4-94,2$ & 100,0 & $99,9-100,0$ & 6,2 & $4,7-7,6$ \\
\hline 8 & $\begin{array}{c}\text { HrHPV } \rightarrow \text { Cito, } \\
\text { corte em }>\text { ASC-US }\end{array}$ & 1.726 & 15.991 & 943 & 15,0 & 63 & 87,5 & $79,9-95,1$ & 94,5 & $94,1-94,8$ & 99,9 & $99,9-100,0$ & 6,7 & $5,1-8,3$ \\
\hline 9 & $\begin{array}{c}\text { Citologia preconizada no } \\
\text { Brasil }\end{array}$ & 15.945 & 0 & 214 & 5,6 & 38 & 52,8 & $41,2-64,3$ & 98,9 & $98,7-99,1$ & 99,8 & $99,7-99,9$ & 17,8 & $12,6-22,9$ \\
\hline 10 & $\begin{array}{l}\text { Citologia preconizada no } \\
\text { Brasil, 25-64 anos }\end{array}$ & 12.631 & 0 & 164 & 4,8 & 34 & 55,7 & $43,3-68,2$ & 99,0 & $98,8-99,1$ & 99,8 & $99,7-99,9$ & 20,7 & $14,5-26,9$ \\
\hline
\end{tabular}


Gráfico 10- Sensibilidade para NIC 2+ e número de colposcopias requeridas de acordo com cada estratégia utilizada

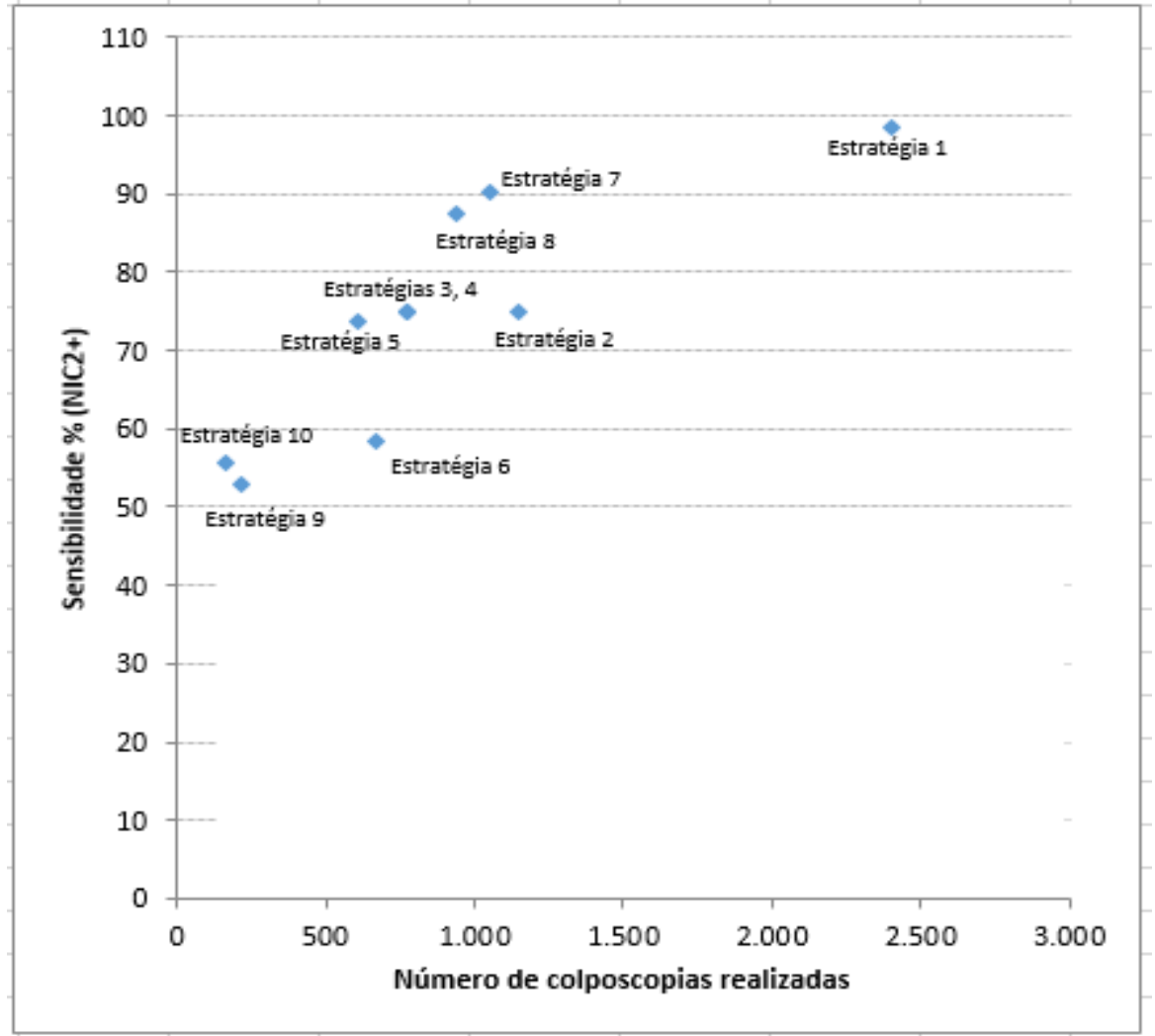

Tabela 9- Número de colposcopias e sensibilidade para NIC 2+ das diferentes estratégias utilizadas.

\begin{tabular}{|c|c|c|c|}
\hline & Estratégias & $\begin{array}{c}\mathrm{N}^{\mathbf{0}} \mathrm{de} \\
\text { colposcopias } \\
\text { realizadas }\end{array}$ & $\begin{array}{c}\text { Sensibilidade } \\
(\mathrm{NIC2}+) \%\end{array}$ \\
\hline 1 & HPV & 2.398 & 98,6 \\
\hline 2 & Citologia & 1.152 & 75 \\
\hline 3 & Coteste corte em ASC-US & 776 & 75 \\
\hline 4 & Cito ASC-US seguida HPV reflexo & 776 & 75 \\
\hline 5 & $\mathrm{HPV}+\rightarrow$ Cito & 606 & 73,6 \\
\hline 6 & HPV com genotipagem 16 e 18 & 672 & 58,3 \\
\hline 7 & $\begin{array}{c}\text { Genotipagem } 16 \text { e } 18+\text { demais HrHPV } \\
\rightarrow \text { Cito, corte em } \geq \text { ASC-US }\end{array}$ & 1.052 & 90,3 \\
\hline 8 & $\begin{array}{c}\text { Genotipagem } 16 \text { e } 18+\text { demais HrHPV } \\
\rightarrow \text { Cito, corte em }>\text { ASC-US }\end{array}$ & 943 & 87,5 \\
\hline 9 & Citologia preconizada no Brasil & 214 & 52,8 \\
\hline 10 & $\begin{array}{l}\text { Citologia preconizada no Brasil, } \\
25-64 \text { anos }\end{array}$ & 164 & 55,7 \\
\hline
\end{tabular}




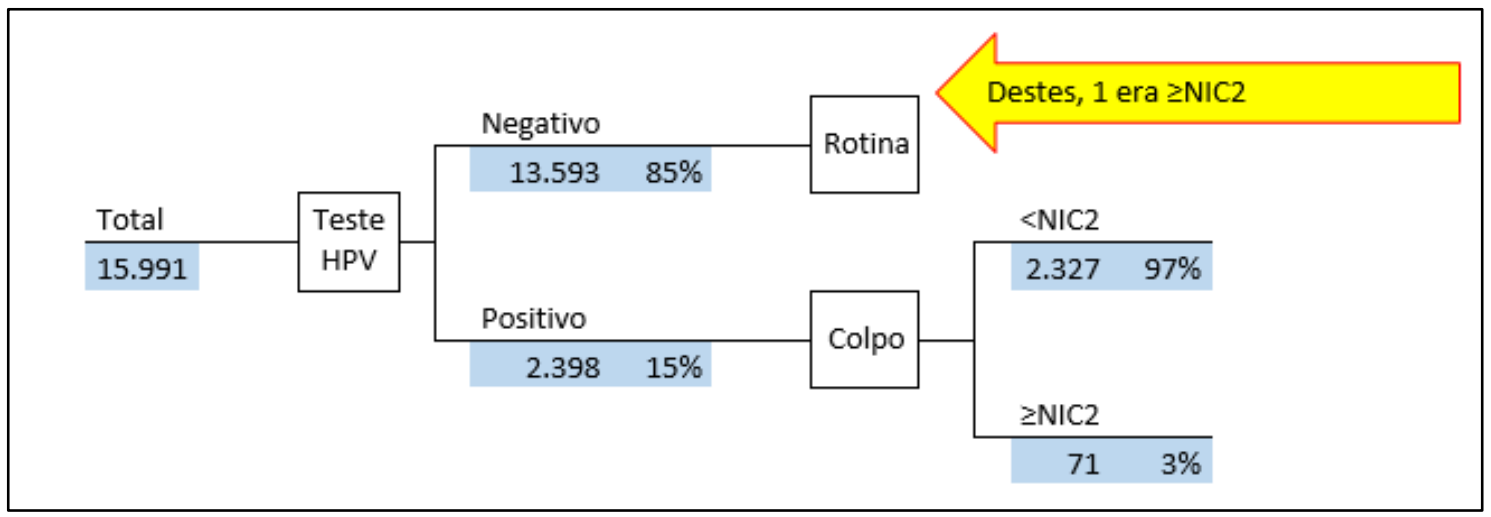

Figura 8- Estratégia 1 - HPV isolado

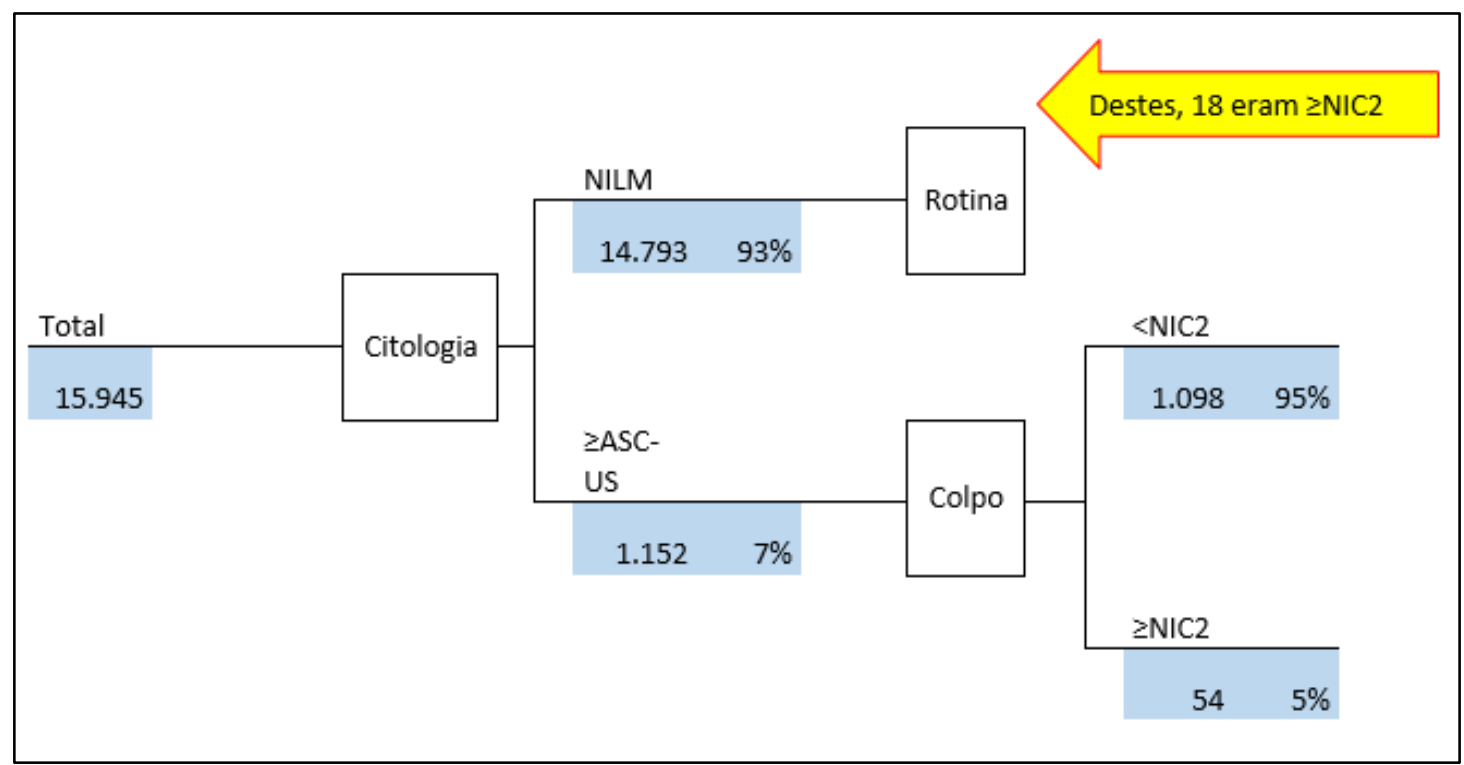

Figura 9- Estratégia 2-Citologia isolada 


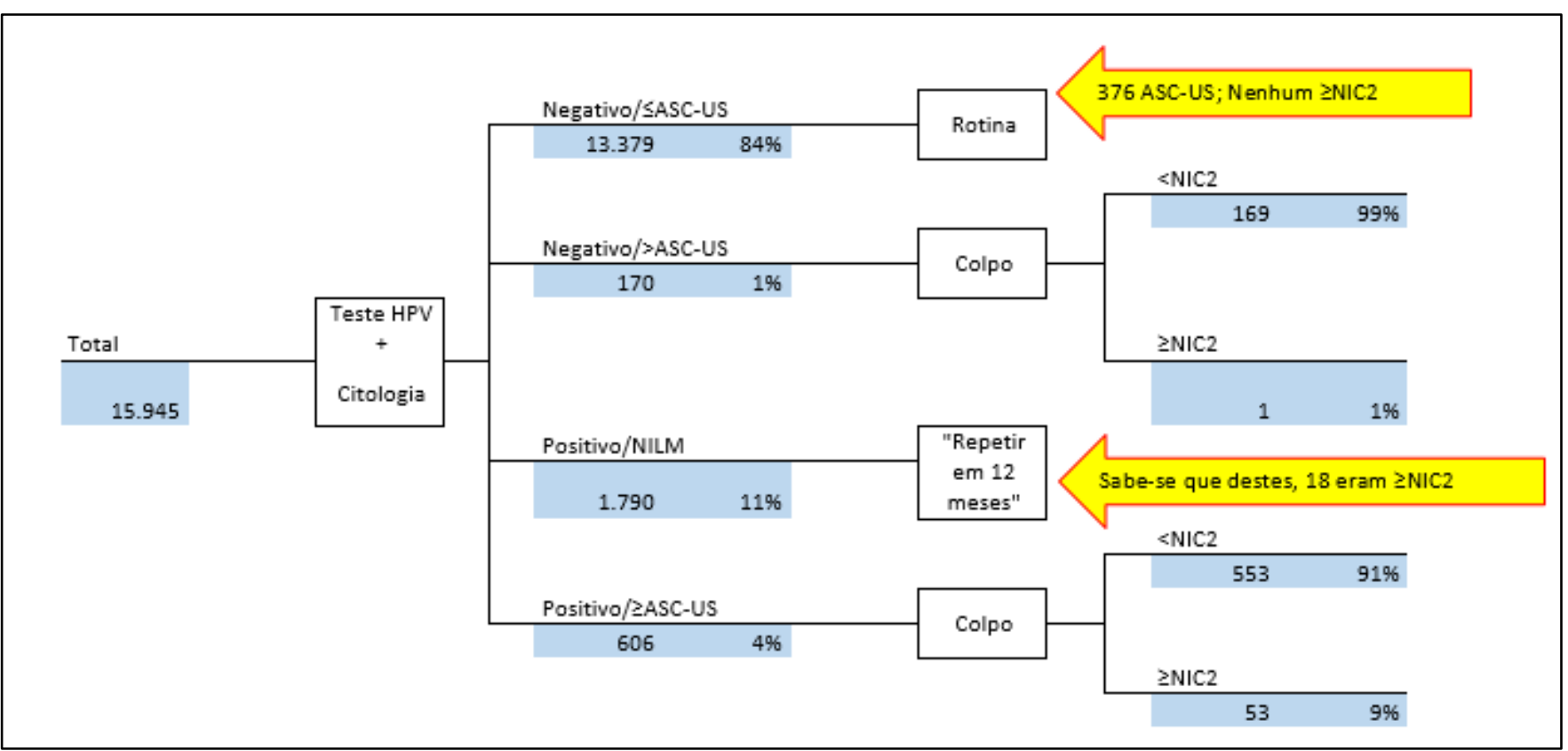

Figura 10- Estratégia 3 - Coteste com corte em ASC-US

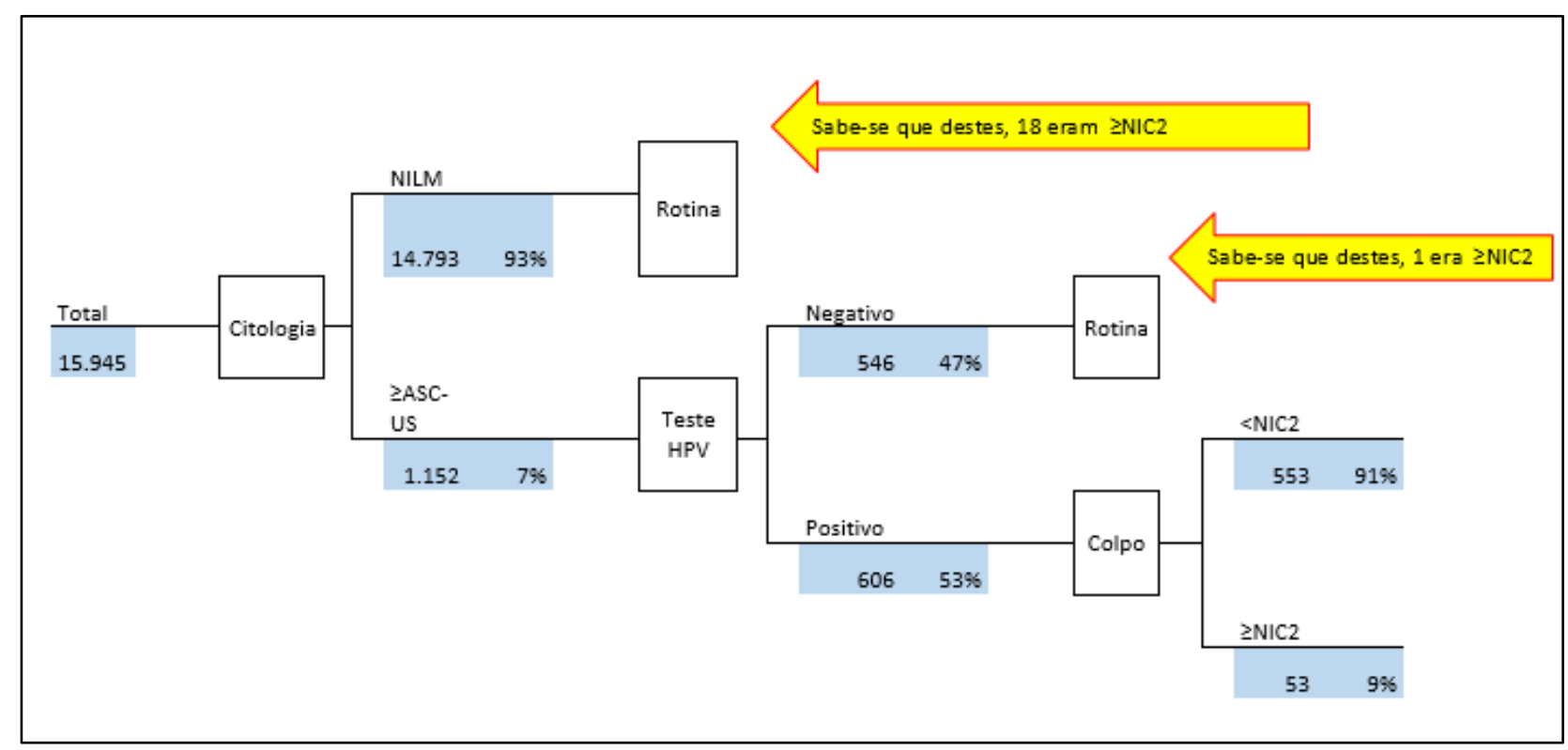

Figura 11- Estratégia 4 - Citologia ASC-US com teste reflexo de HPV 


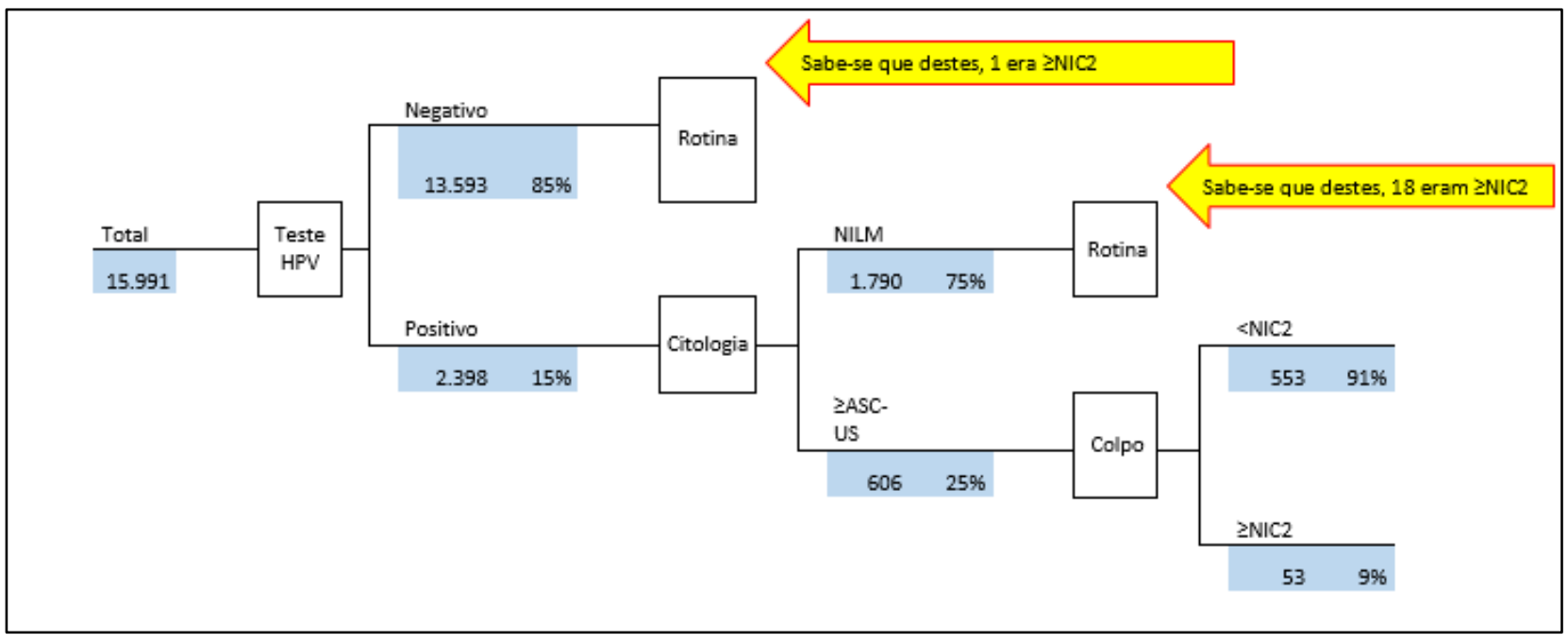

Figura 12- Estratégia 5 - HPV + seguido de triagem citológica

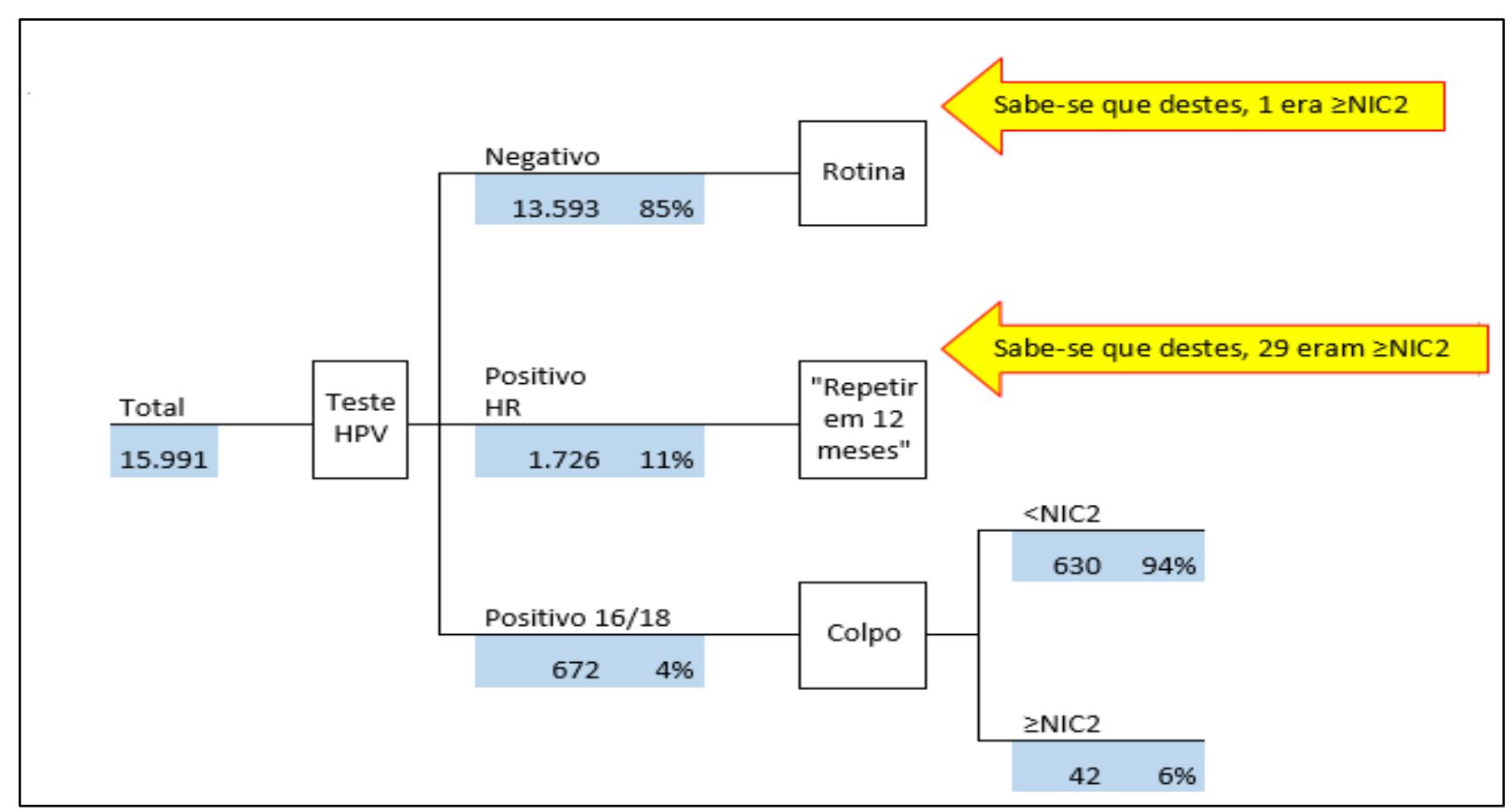

Figura 13- Estratégia 6 - HPV com genotipagem 16/18, HR: HPV de alto risco (não 16 e 18). 


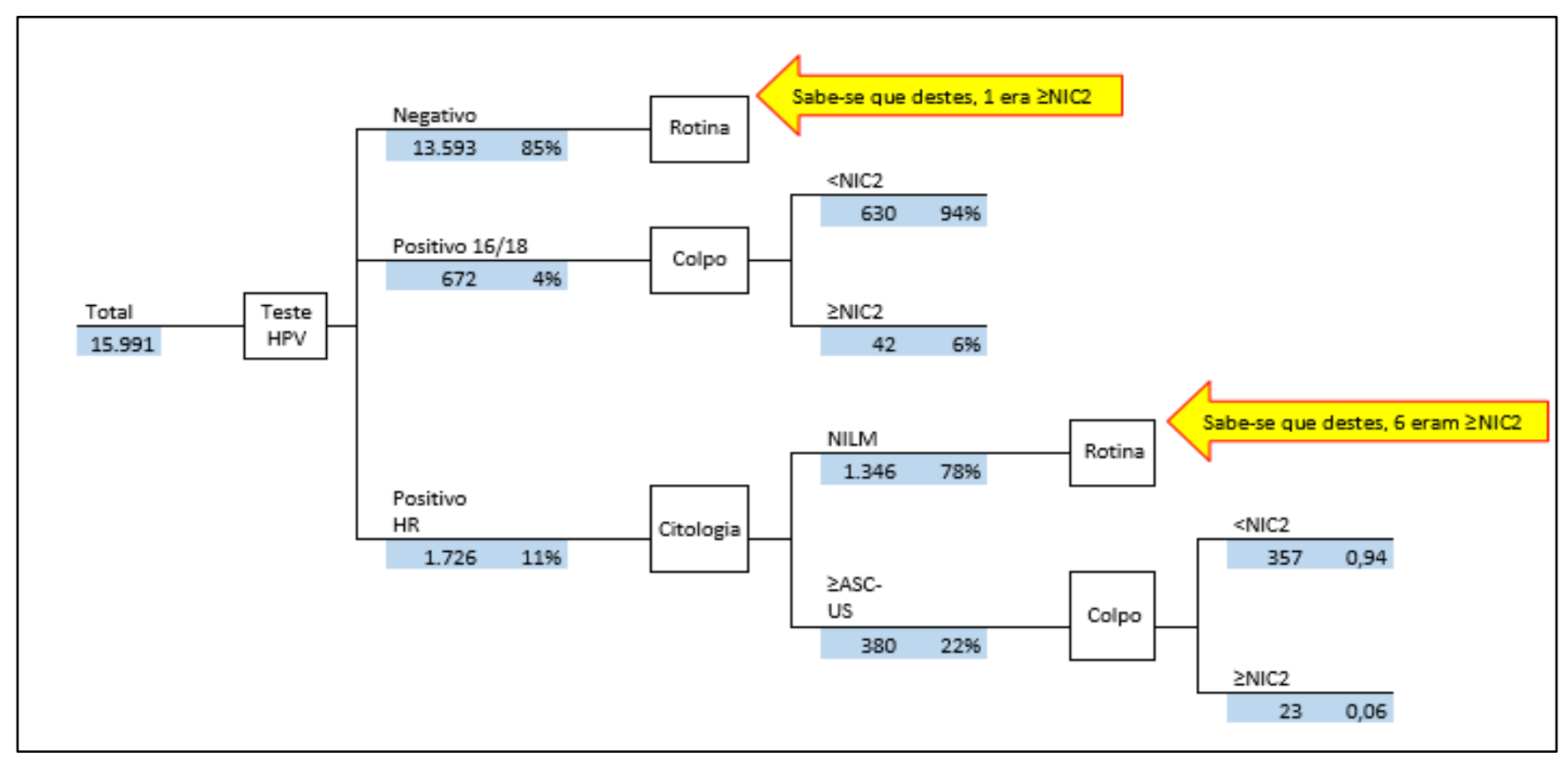

Figura 14- Estratégia 7 - Genotipagem 16 e $18+$ demais HrHPVs $\rightarrow$ Cito, corte em $\geq$ ASC-US. HR: HPV de alto risco (não 16 e 18).

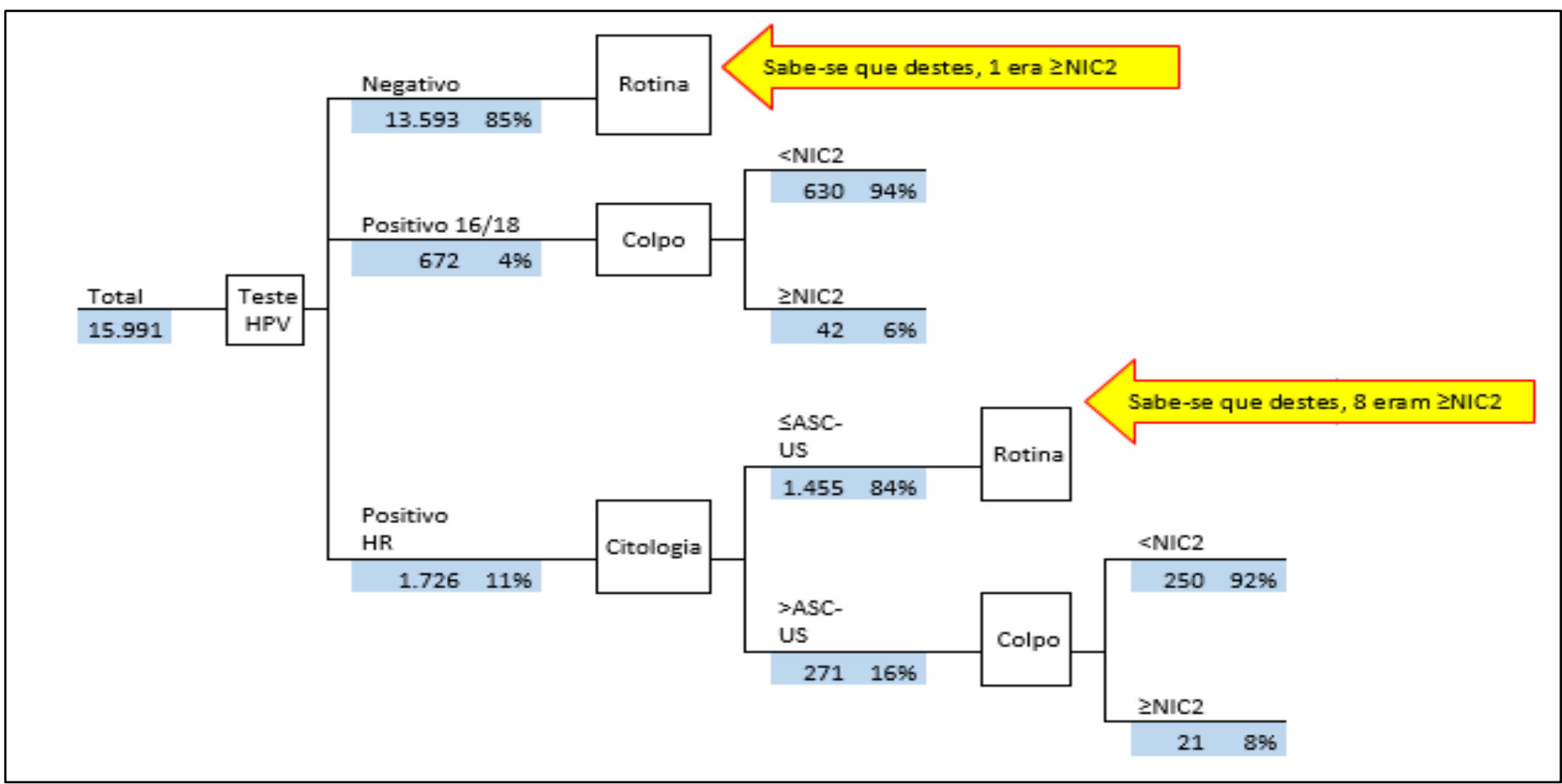

Figura 15- Estratégia 8 - Genotipagem 16 e $18+$ demais HrHPVs $\rightarrow$ Cito, corte em > ASC-US. HR: HPV de alto risco (não 16 e 18). 


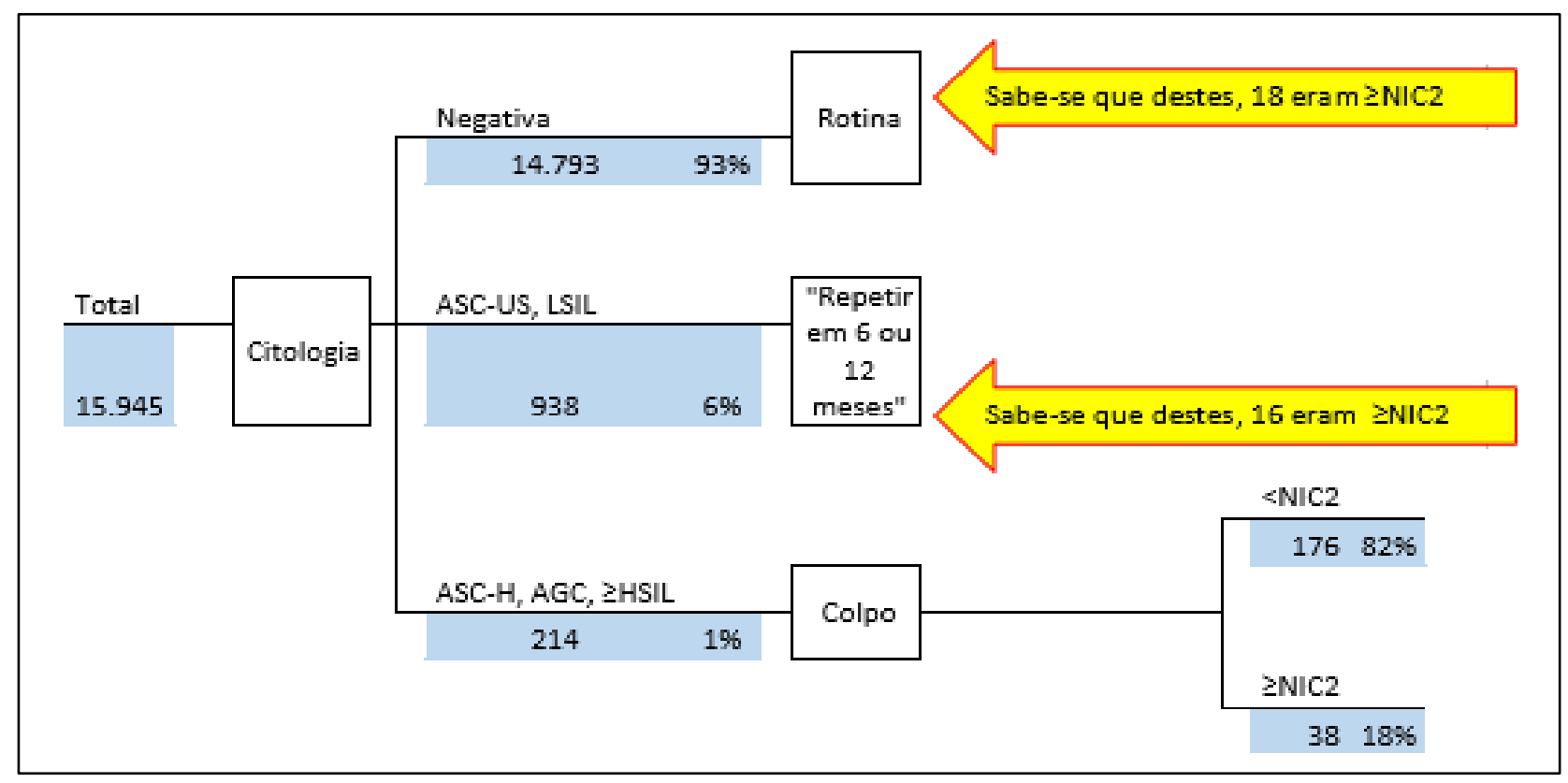

Figura 16- Estratégia 9 - Citologia preconizada no Brasil.

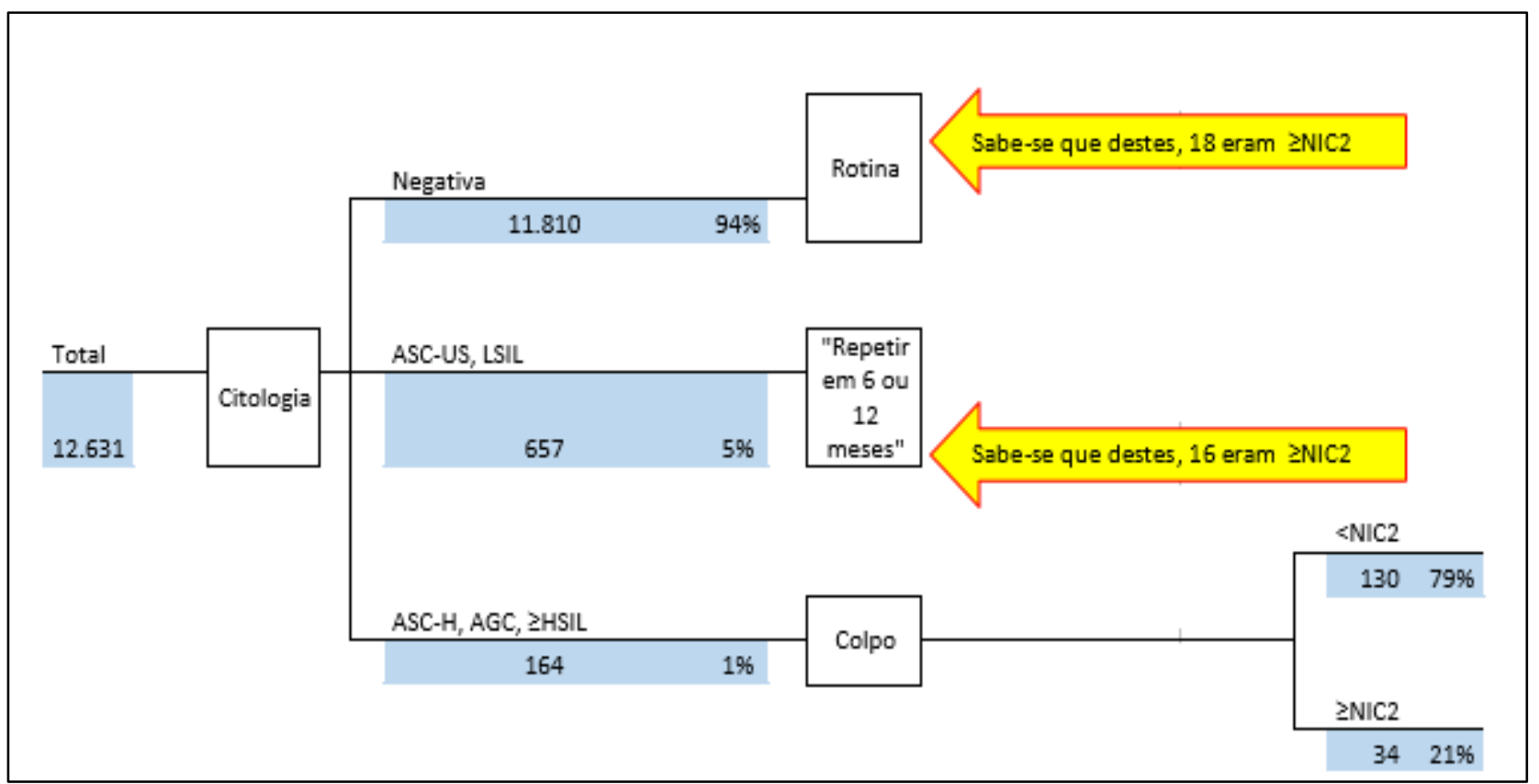

Figura 17- Estratégia 10 - Citologia preconizada no Brasil 25 a 64 anos. 


\subsection{Comparação de estratégias (algoritmos) de rastreio e triagem tendo como desfecho os casos NIC 3+.}

Com base nos resultados das estratégias obtidos para NIC 2+ como desfecho, foram avaliadas 4 diferentes estratégias tendo NIC 3+ como endpoint: rastreio baseado em teste HPV (estratégia 1), rastreio citológico (estratégia 2) e as estratégias 3 e 4 utilizando o teste de HPV como rastreio primário com genotipagem 16/18 combinando a citologia em diferentes "thresholds": > ou = ASC-US e > ASC-US respectivamente para os demais HrHPVs.

A estratégia 1 (teste HPV) apresentou sensibilidade de 100\%, detectando todos os casos NIC 3+ como já mencionado anteriormente e especificidade de $85,1 \%$, sendo necessárias 184,5 colposcopias para detectar um caso de NIC $3+$, enquanto que a citologia isolada (estratégia 2) apresentou sensibilidade de $84,6 \%$, uma especificidade maior $92,8 \%$, sendo necessárias 104,7 colposcopias para cada caso de NIC $3+$. A combinação teste de HPV e citologia (estratégias 3 e 4), com genotipagem dos HPVs 16 e 18 seguido de colposcopia e demais genótipos com triagem citológica, apresentou sensibilidade de $100 \%$ para a estratégia 3, superior à estratégia 4, a qual teve uma sensibilidade de $92,3 \%$ (12/13) com um ligeiro aumento na especificidade. Ambas estratégias tiveram praticamente o mesmo número de colposcopias requeridas para detectar um caso de NIC 3+, 80,9 e 78,6 respectivamente como demonstrado na Tabela 10, a Figura 18 demonstra a estratégia 3. 
Tabela 10- Resultados das diferentes estratégias para a detecção de NIC 3+

\begin{tabular}{|c|c|c|c|c|c|c|c|c|c|c|c|c|c|c|}
\hline \multirow{2}{*}{\multicolumn{2}{|c|}{ Estratégias }} & \multirow{2}{*}{$\begin{array}{l}\text { № de } \\
\text { citologias } \\
\text { realizadas }\end{array}$} & \multirow{2}{*}{$\begin{array}{l}\text { No de } \\
\text { testes de } \\
\text { HPV } \\
\text { realizado } \\
\text { S }\end{array}$} & \multirow{2}{*}{$\begin{array}{l}\text { № de } \\
\text { colposcopia } \\
\text { s realizadas }\end{array}$} & \multirow{2}{*}{$\begin{array}{l}\text { No de } \\
\text { colposcopias } \\
\text { para detectar } 1 \\
\text { caso de NIC3+ }\end{array}$} & \multirow{2}{*}{$\begin{array}{c}\text { № de casos } \\
\text { de NIC3+ } \\
\text { identificados }\end{array}$} & \multicolumn{2}{|c|}{$\begin{array}{c}\text { Sensibilidade } \\
\text { (NIC3+) }\end{array}$} & \multicolumn{2}{|c|}{$\begin{array}{c}\text { Especificidade } \\
(\mathrm{NIC3}+)\end{array}$} & \multicolumn{2}{|c|}{ VPN (NIC3+) } & \multicolumn{2}{|c|}{ VPP (NIC3+) } \\
\hline & & & & & & & & IC de $95 \%$ & & IC de $95 \%$ & & IC de $95 \%$ & & IC de $95 \%$ \\
\hline 1 & Teste HPV somente & 0 & 15.991 & 2.398 & 184,5 & 13 & 100,0 & $100,0-100,0$ & 85,1 & $84,5-85,6$ & 100,0 & $100,0-100,0$ & 0,5 & $0,2-0,8$ \\
\hline 2 & Cito somente & 15.945 & 0 & 1.152 & 104,7 & 11 & 84,6 & $65,0-104,2$ & 92,8 & $92,4-93,2$ & 100,0 & $100,0-100,0$ & 1,0 & $0,4-1,5$ \\
\hline 3 & $\begin{array}{c}\text { Teste HPV HR } \rightarrow \text { Cito, } \\
\text { corte em } \geq \text { ASC-US }\end{array}$ & 1.726 & 15.991 & 1.052 & 80,9 & 13 & 100,0 & $100,0-100,0$ & 93,5 & $93,1-93,9$ & 100,0 & $100,0-100,0$ & 1,2 & $0,6-1,9$ \\
\hline 4 & $\begin{array}{c}\text { Teste HPV HR } \rightarrow \text { Cito, } \\
\text { corte em }>\text { ASC-US }\end{array}$ & 1.726 & 15.991 & 943 & 78,6 & 12 & 92,3 & $77,8-106,8$ & 94,2 & $93,8-94,5$ & 100,0 & $100,0-100,0$ & 1,3 & $0,6-2,0$ \\
\hline
\end{tabular}




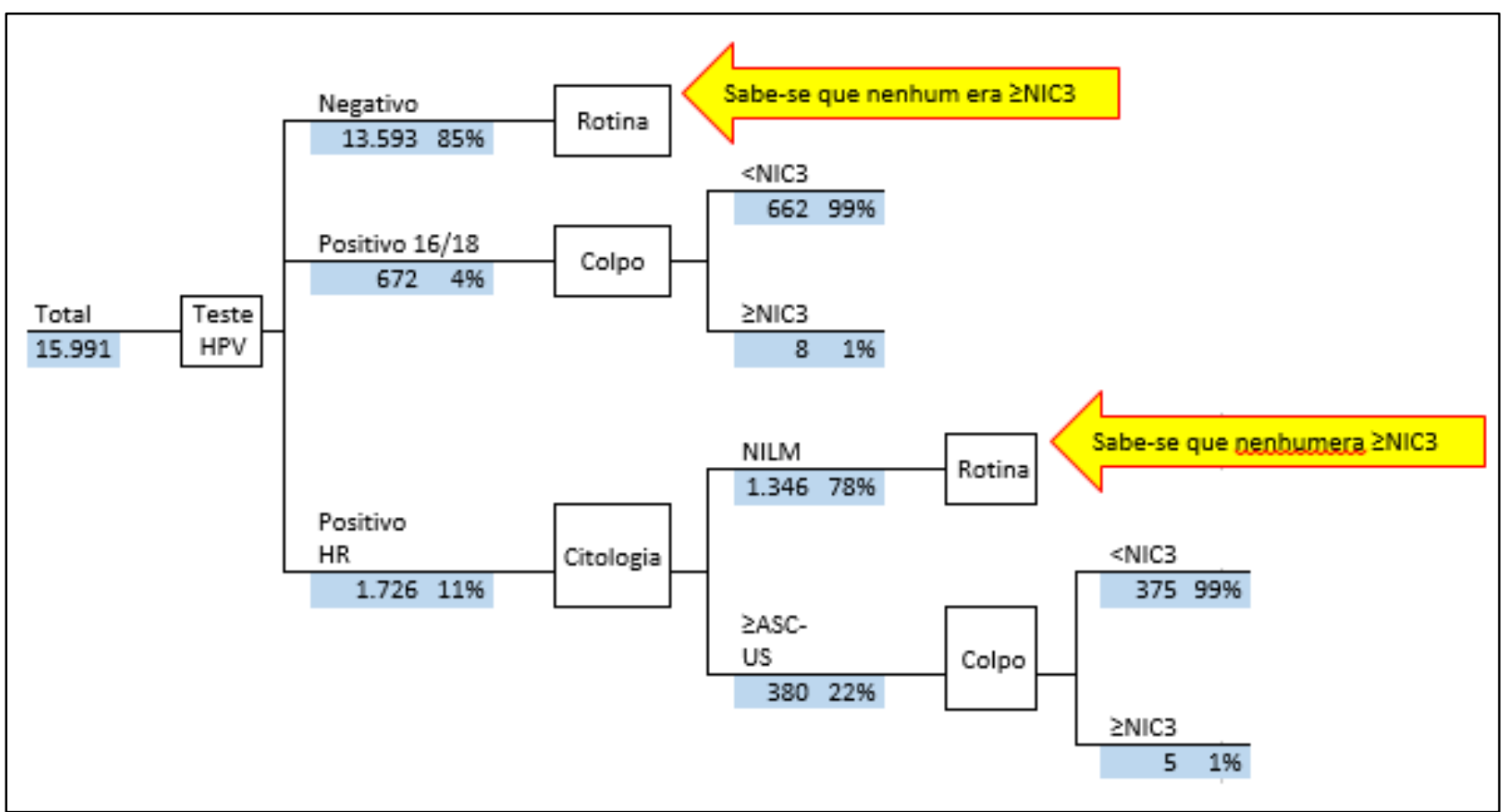

Figura 18- Estratégia 3 - Genotipagem 16 e $18+$ demais HrHPV $\rightarrow$ Cito, corte em $\geq$ ASC-US. HR: HPV de alto risco (não 16 e 18). 
6. Discussão 


\subsection{Citologia oncótica e HrHPV}

Durante os últimos 60 anos, a Citologia Oncótica (Papanicolaou) tem sido o principal teste de rastreio para a prevenção do câncer cervical. Apesar do importantíssimo papel no decréscimo da incidência desta neoplasia, principalmente nos países desenvolvidos, há discussões a respeito de suas limitações no que diz respeito a sensibilidade, especificidade e reprodutibilidade (Dillner et al., 2008). O conhecimento científico sobre o câncer cervical e HPV, que tem sido ampliado nas últimas décadas, abre a possibilidade de se aumentar as estratégias de prevenção associando-se métodos de rastreamento.

Evidências atuais de estudos randomizados suportam a incorporação de métodos de prevenção que detectam o HPV, a causa do câncer do colo do útero, em diferentes cenários de programas de rastreio (Schiffman et al., 2011). O interesse no uso dos testes de HPV como metodologia de rastreamento se baseia no fato de que o DNA do vírus está presente em quase todos os casos de câncer cervical, os quais apresentam maior sensibilidade (60-70\%) do que a citologia oncótica para os casos de carcinomas cervicais invasivos (Ronco et al., 2014).

Este estudo fornece dados epidemiológicos atuais da prevalência de anormalidades citológicas, histológicas e prevalência dos HrHPV em uma população de rastreio do câncer cervical. Pelo nosso conhecimento é o estudo com maior número de mulheres recrutadas no Brasil, comparando as performances do teste citológico e molecular como ferramentas de rastreio deste tipo de câncer. Os dados epidemiológicos obtidos poderão ser úteis para estratégias de prevenção, políticas de saúde públicas e elaboração de diretrizes futuras voltadas para a prevenção do câncer de colo do útero. 
Os resultados citológicos em nosso estudo se apresentam dentro de uma distribuição comum para uma população de rastreamento, as taxas de anormalidades citológicas encontradas 7,2\% de positividade distribuídos em 3,4\% de ASC-US, 2,5\% de LSIL e 0,5\% de HSIL estão de acordo com o que é apontado pelo Manual de Gestão de Qualidade para Laboratório de Citopatologia (2016), o qual preconiza índice de positividade > ou $=3,0 \%$; para ASC-US até no máximo $5 \%$ de todos os exames e para HSIL o Ministério da Saúde estabeleceu o parâmetro de $\geq 0,4 \%$ para o indicador de HSIL/ total de exames satisfatórios (Manual Gestão, 2016). Estes dados corroboram os achados reportados em estudo conduzido pelo Colégio Americano de Patologistas com índice médio de anormalidades citológicas de 4,3\% para ASC-US, 2,5\% para LSIL e 0,5\% para HSIL (Galen et al., 2006).

Os índices de anormalidades citológicas, como esperado, decresceram com o aumento da faixa etária; uma configuração que se apresenta em diferentes estudos como o de Kaiser Permanente, Northen California (Castle et al., 2009a) com taxas de positividade de $6,5 \%, 5,7 \%, 5,6 \%$ e 3,2\% respectivamente para as faixas etárias de 30 a 34; 35 a 39; 45 a 49 e 60 a 64 anos. Quando comparamos com nosso estudo os seguintes índices de positividade $8,7 \% ; 6,0 \% ; 5,7 \%$ e $4,0 \%$ foram encontrados para as mesmas faixas etárias.

Um dos achados notáveis que observamos está relacionado a qualidade das amostras citológicas, apenas $0,3 \%$ de amostras insatisfatórias refletindo neste aspecto, a superioridade da citologia em meio líquido em relação à citologia convencional, achado bem documentado na literatura (Ronco et al., 2007). O laboratório da FOSP realiza mais de 200.000 exames de Papanicolaou anualmente, e previamente ao início deste projeto, foi realizada uma etapa de adaptação ao sistema de meio líquido, envolvendo treinamento dos profissionais de saúde nas UBSs e 
profissionais envolvidos na FOSP. Posteriormente, ao compararmos a performance da citologia em meio líquido ao Papanicolaou convencional, a proporção de casos insatisfatórios foi muito mais elevada em amostras convencionais do que no meio líquido $(2,7 \%$ vs $0,3 \%)$, totalizando mais de 6.000 casos pela citologia convencional (Longatto-Filho et al., 2015). Se considerarmos que o Governo Brasileiro com o objetivo de prevenção do câncer de colo do útero financia mais de 10 milhões de exames de Papanicolaou por ano, 3\% de casos insatisfatórios representa aproximadamente a repetição dos exames por 300.000 mulheres, resultando em duplicidade do processo, gastos e desconforto para as pacientes mediante realização de novo exame, deslocamentos e ajustes na rotina diária.

Ainda em relação ao mesmo estudo, o índice de positividade praticamente dobrou ao compararmos os dois métodos citológicos, de 3,0 \% para 5,7\%, o que encoraja a incorporação da citologia em meio líquida pelo Sistema Único de Saúde, estratégia que pode representar um grande impacto na política de saúde pública voltada para a prevenção do câncer cervical (Longatto-Filho et al., 2015).

Diante dos avanços tecnológicos, o laboratório moderno de citologia está indo além do teste de Papanicolaou realizado por leitura manual, incorporando uma préleitura guiada por inteligência artificial (guiada por computador) que informa probabilidades de se encontrar anormalidades com base em escores dos quintis, proporcionando aos citotécnicos, citologistas e patologistas recursos adicionais na leitura da lâmina com o intuito de melhorar o reconhecimento de anormalidades celulares, incrementando o diagnóstico citológico, melhorando a sensibilidade e sendo um benefício direto principalmente para aqueles laboratórios com maiores taxas de resultados falso-negativos (Joste \& Gober-Wilcox, 2013). Nossos achados demonstram que o sistema Focalpoint classificou os dois casos de carcinoma no Q1 e a maioria dos 
casos HSIL e ASC-H nos Q1 e Q2, o que aponta favoravelmente para o uso de rastreio assistido por computador na rotina diária evitando resultados falso-negativos. Em um dos casos, o qual teve diagnóstico histológico de Adenocarcinoma e citológico de ASCH, o Focalpoint classificou a amostra dentro do Q4, este caso está representado na Tabela 6. Ao realizarmos a revisão desta lâmina, as alterações morfológicas eram bem evidentes e mantivemos a classificação de ASC-H, não anulando a enorme contribuição da leitura guiada por computador que mostrou boa performance e contribuição. Demais casos discordantes como leitura manual ASC-H e quintis elevados também foram revisados e não mostraram maiores inconsistências. Vale lembrar que o mesmo não emite o diagnóstico, mas sim serve como um parâmetro a mais para os profissionais que realizam a leitura citológica.

A prevalência de HrHPV encontrada neste estudo (15\%) é similar a outros estudos conduzidos no Brasil, como na metanálise realizada por Ayres e colaboradores (2010) e superior aos achados de Levi et al. (2014), que em uma população de rastreio reportaram 9\% de positividade para HrHPV (Levi et al., 2014).

O DNA do HPV esteve presente em $12,1 \%$ das citologias classificadas como negativas. Em uma metanálise com mais de 1 milhão de citologias negativas, a estimativa global do DNA do HPV foi de $11,7 \%$, tendo a América Latina apresentado uma positividade de 16,1\% para essas citologias (Bruni et al., 2010). De acordo com Castellsagué (2008), o DNA viral é detectado na maioria dos casos (70\%-90\%) das lesões precursoras ou das lesões intraepiteliais escamosas de alto grau - HSIL (NIC 2 e 3), $20 \%$ a $50 \%$ das lesões intraepiteliais escamosas de baixo grau - LSIL (NIC 1) e $50 \%$ nas atipias celulares escamosas e glandulares de significado indeterminado ASCUS e AGUS e em praticamente $100 \%$ dos casos de câncer cervical, apontando 
claramente o HPV como principal causa do câncer cervical invasivo (Castellsagué, 2008).

Embora os testes baseados na detecção do DNA do HPV apresentem um alto valor preditivo negativo (VPN), de aproximadamente 100\% (Clavel et al., 2001; Zielinski et al., 2004), resultados falso-negativos ocorrem, mas há poucos relatos dessas raras ocorrências. Nossos dados mostraram positividade em 73,2\% dos casos de LSIL, $87,4 \%$ de HSIL e em $100 \%$ dos casos de carcinoma epidermóide invasivo. Os 12,6\% das amostras classificadas como HSIL (11/87) e HPV negativas são valores próximos aos descritos por Guo et al., (2004), que reportou 13,6\% dos casos de HSIL negativos para o ensaio de HPV. De Cremoux e colaboradores (2003), relatam que apesar da alta sensibilidade dos métodos moleculares, a não detecção do genoma viral pode ocorrer em $5 \%$ a $10 \%$ dos casos de câncer invasivo, 10-15\% dos casos de lesões intraepiteliais de alto grau (HSIL) e de 20-30\% dos casos de lesões intra-epiteliais de baixo grau (LSIL), há uma relação clara entre a positividade do HPV e o grau de severidade da doença. O grau de discariose está associado à infecção persistente pelo HPV, enquanto que as anormalidades menores são mais frequentemente associadas às lesões ou infecções transitórias (Castellsagué, 2008).

Resultados falso-negativos podem ser decorrentes da sensibilidade do método utilizado, deleção ou rearranjo do gene do HPV a ser detectado; presença de um novo tipo de HPV não detectado pela(s) metodologia(s) empregada(s); amostra inadequada (Herrington, 1999), ou atribuíveis a erros na classificação morfológica (Castle et al., 2008; de Sanjose et al., 2010). Já os resultados verdadeiramente negativos podem estar relacionados às infecções transitórias pelo HPV, perda de sequências do gene viral, ou desenvolvimento de um tumor através de uma via HPV-independente (Herrington, 1999). Vale salientar que dos 11 casos de HSIL com DNA do HPV negativo em nosso 
estudo, 10 permaneceram sem retorno do seguimento colposcópico, o que limita nossa avaliação referente a esses casos em questão.

Os HPVs dos grupos P3 (35/39/68) e P2 (56/59/66) foram os mais frequentes em nosso estudo, seguidos dos tipos 16 e 52. A maior frequência do HPV 16 é comumente reportada em diferentes estudos de rastreio (de Ona et al., 2010). A distribuição e prevalência dos genótipos de HPV varia de acordo com o grau da doença, idade e localização geográfica das pacientes (Fernandes et al., 2009; Ottero-Motta et al., 2011; Levi et al., 2014; Bruno et al., 2014).

Ilustrando a variabilidade geográfica, no Brasil, os HPVs 31 e 33 são os segundos tipos mais prevalentes (Baldez da Silva et al., 2009; Rabelo-Santos et al., 2003) em populações selecionadas, respectivamente, nas regiões Nordeste e Central. Surpreendentemente, o HPV 66 foi detectado em $22 \%$ das amostras positivas para HPV de Campo Grande, Mato Grosso do Sul (Tozetti et al., 2006) e o HPV 58 foi o tipo mais freqüente $(19,8 \%)$ em mulheres infectadas pelo HIV seguido de HPV 53 (15,5\%) na região Sudeste (Castilho et al., 2015).

Levi e colaboradores (2014) reportaram o HPV 56 em aproximadamente 9\% das amostras de mulheres em uma população de rastreio e em 13\% das mulheres com histórico de Papanicolaou prévio alterado, corroborando os resultados de Bruno et al (2014), que em estudo conduzido no Estado da Bahia, detectou o genótipo 56 em 14\% das amostras cervicais. Diante da elevada frequência exposta neste estudo, os DNAs das amostras positivas para os HPVs P2 (56/59/66) e P3 (35/39/68) foram resgatados e acondicionados adequadamente, requerendo futura investigação com primers específicos de maneira a individualizar os genótipos e estabelecer as reais estimativas dos mesmos. 
Estudos mostram que a contribuição de HPV-16 e 18 nos casos de câncer cervical varia de 62,4 a 72,6\% (Noronha et al., 1999; Fernandes et al., 2010; Sanjosé et al., 2010; Li et al., 2011). As diretrizes atuais dos EUA recomendam a genotipagem apenas para HPV 16 e 18, e a detecção de qualquer um desses dois tipos de HPV é suficiente para justificar o encaminhamento direto à colposcopia, evitando métodos de triagem adicionais (Wentzensen et al., 2015). No entanto, alguns estudos sugeriram que também pode ser clinicamente útil identificar outros tipos de HPV, como o HPV 31, 33, 33/58 (combinado), que apresentaram risco comparável ou aumentado para o desenvolvimento de NIC 2+ (Wright et al., 2014).

Em nossa casuística o HPV 16 foi encontrado em 49,2\% dos casos de NIC 2, 57,1\% dos casos de NIC 3 e em $100 \%$ dos adenocarcinomas, já o HPV 18 foi muito menos frequente, encontrado em $8,5 \%$ dos casos de NIC 2 e em um caso de carcinoma in situ. Os demais HrHPV corresponderam há 40,7\% dos casos de NIC 2 e $38,5 \%(5 / 13)$ dos casos de NIC $3+$.

Cabe ressaltar que o rastreamento do câncer cervical tem como objetivo a detecção de lesões de alto grau precursoras (NIC 2 e NIC 3), onde outros genótipos de alto risco tem grande participação. Neste contexto, o HPV 31 e especialmente o HPV 33 figuram como tipos importantes apresentando valor preditivo positivo maior do que o HPV 18. Em adição, a genotipagem estendida indica que os tipos 39, 56, 59, 66 e 68 apresentam menores valores preditivos positivos quando comparados aos HPVs 16, 18, 31, 33, 35, 45, 51, 52 e 58 (Cuzick et al., 2016). Com a introdução dos programas de vacinação, a genotipagem do HPV pode ser uma ferramenta essencial para avaliar a efetividade do programa, identificando o perfil genotípico pré e pós vacinação. 
Ao avaliarmos os genótipos de HrHPVs incluídos no ensaio BD Onclarity HPV ${ }^{\circledR}$ por espécies de acordo com a classificação de Villiers et al., (2004), o grupo P2, o segundo mais frequente $(3,4 \%)$ como mencionado anteriormente, inclui os HPVs 56 e 66 os quais pertencem à espécie alfa-6, espécie não inserida na profilaxia primária pelas vacinas antiHPVs. A nova geração de vacinas nonavalente inclui proteção contra as espécies alfa-9 (HPVs 16, 31, 33, 35, 52 e 58) e alfa-7 (HPVs 18, 39, 45, 59 e 68).

Embora o HPV 56 tenha sido um achado comum em outros estudos brasileiros como anteriormente mencionado, o grupo P2 onde o HPV 56 se inclui, foi encontrado somente em $6,8 \%$ dos casos de NIC 2 e em nenhum caso de NIC $3+$, sugerindo baixo potencial oncogênico, corroborando os dados de Oliveira et al., (2013), que não encontrou o HPV 56 em nenhum dos 175 casos de carcinoma epidermóide invasor em estudo conduzido em São Paulo.

A redução observada na prevalência dos HPVs com o aumento da idade é consistente com outros estudos, como o ATHENA (Addressing the Need for Advanced HPV Diagnostics) um grande estudo prospectivo, multicêntrico para o rastreio do câncer cervical nos EUA, com mais de 47 mil mulheres, onde a prevalência de $30,5 \%$ na faixa etária de 21 a 24 anos decresceu para $6,6 \%$ ou menos nas mulheres com idade compreendida entre 45 a 93 anos de idade (Wright et al., 2012). No estudo Kaiser Permanente Northen California, outro estudo com o rastreio molecular estabelecido, a prevalência foi de 10,8\% em mulheres de 30 a 34 anos e inferior a 5\% na faixa etária de 45 a 79 anos (Castle et al., 2009a). Em nosso estudo, a faixa etária até 24 anos apresentou uma prevalência de 40,7\% de positividade para o HPV, enquanto que para as mulheres com idade de 30 a 34 anos a taxa encontrada foi de $17,4 \%$ e de 60 a 64 anos de $6,5 \%$. Em contraste, um pico 
de $43 \%$ de positividade foi observado em mulheres com história prévia de Papanicolaou alterado na faixa etária entre 61 e 65 anos em uma população de São Paulo e Barretos, tendo como hipótese para este efeito desvio amostral devido ao pequeno número de amostras nesta faixa etária $(\mathrm{n}=21)$ (Levi et al., 2014), achado semelhante a os de San José et al 2007, que em uma metanálise com 157.879 mulheres com citologias normais, um segundo pico da prevalência do HPV foi evidente em mulheres com 45 anos ou mais na África, América e Europa.

A prevalência geral de NIC $2+$ das mulheres submetidas a biópsia foi de $21,6 \%$ (72/334). Vale lembrar que neste estudo mulheres com ambos testes negativos não realizaram colposcopia, o que poderia produzir uma estimativa com maior acurácia da prevalência de lesão de alto grau das mulheres submetidas ao rastreio do câncer cervical. Ao contrário, o estudo ATHENA selecionou $10,7 \%$ (895/8.383) das mulheres com ambos resultados de citologia e HPV para exame colposcópico e biópisas aleatórias nos 4 quadrantes, reportando nestes casos uma positividade de 5,9\% (497/8.383) para NIC 2+ (Wright et al., 2012). Em outro estudo, este realizado no Chile, com 8.265 mulheres, Ferrecio e colaboradores (2013) reportaram uma taxa superior aos nossos achados, 28,9\% (91/315) de NIC 2+ entre as amostras encaminhadas para a biópsia. Uma positividade adicional de 2,2\% (5/230) casos foi observada em mulheres com resultados negativos de citologia e teste de HPV que também foram encaminhadas à colposcopia.

As possíveis explicações para a variabilidade na prevalência estimada de NIC de alto grau na população de rastreio incluem fatores de risco diferentes para NIC e 
histórias de rastreio prévias dos participantes, critérios patológicos utilizados para o diagnóstico e se os patologistas foram cegos para as respectivas análises (TorresIbarra et al., 2016). Em nosso estudo, os profissionais que realizaram tanto a colposcopia quanto a histologia tinham conhecimento prévio do resultado prévio do HPV.

Ainda, recentes estudos tem documentado que o exame colposcópico possui um baixa taxa de detecção de lesões, argumenta-se que $30 \%$ das mesmas não são visíveis durante o exame, uma dificuldade até para os profissionais mais experientes, e sugere-se como alternativa a coleta de biópsias por quadrante, com a melhora da sensibilidade da colposcopia na detecção de NIC 2+ em até 37\% (Porras et al., 2012; Monsonego et al., 2015; Nam et al., 2010; Gage et al., 2006), uma medida importante para garantir a detecção de casos CIN2 + que requerem tratamento imediato.

Numerosos estudos tem confirmado que o teste de HPV oferece benefícios na prevenção quando comparado à citologia. Ao contrário da citologia, o teste HrHPV é objetivo, reprodutível e com maior sensibilidade e valor preditivo negativo, o que reduz as taxas de resultados falso negativos geralmente encontrados no Papanicolaou (Whitlock et al., 2011). A detecção de DNA do HPV pode ser associada a uma redução significativa do número de casos de câncer cervical avançado e mortes em decorrência dessa neoplasia (Sankaranarayanan et al., 2009) já que o resultado negativo nesse teste garante baixíssimo risco de desenvolvimento de NIC 3 nos seis anos seguintes à realização do mesmo (Ronco et al, 2014). O aumento no intervalo de exames com segurança é um dos principais motivos da custo-efetividade do rastreio molecular, pois reduz o número de testes (Flores et al., 2011; Vijayaragavan et al., 2009). 
Entre o teste de HrHPV e a citologia, nossos resultados demonstraram que o teste de HPV detectou 98,6\% das amostras de NIC 2 e $100 \%$ dos casos de NIC 3+, enquanto a citologia $75 \%$ e $84,6 \%$ respectivamente, com redução na especificidade $85,4 \%$ vs $93,1 \%$ para NIC 2 e de $85,1 \%$ para $92,8 \%$ para NIC 3, resultados superiores aos descritos por Ferrecio et al (2013) onde o teste de HPV detectou 92,9\% dos casos de NIC 2 e 96,3\% dos casos de NIC 3, enquanto a performance da citologia foi bem inferior, detectando $28,6 \%$ dos casos de NIC 2 e 38,9\% de NIC 3, sendo esta baixa performance da citologia atribuída a uma queda no controle de qualidade por sobrecarga de trabalho, limitação do teste citológico já bem documentada. Mayrand e colaboradores (2007) em estudo realizado no Canadá com 10.154 mulheres também endossam a sensibilidade superior em aproximadamente $40 \%$ do diagnóstico molecular comparado à citologia para a detecção de NIC 2+.

Estudo realizado nas cidades de São Paulo e Campinas mostrou que 86,5\% das pacientes com alterações citológicas e 92,8\% das com alterações histológicas haviam feito exame citopatológico anterior em período inferior a três anos, o que sugere a ocorrência de resultados falso-negativos nos exames citopatológicos anteriores ou falha nos mecanismos de seguimento das pacientes (Rama et al., 2008).

A alta sensibilidade do teste de HrHPV se utilizado como método de rastreio primário do câncer cervical apresenta uma alta taxa de resultados positivos, em nosso estudo observamos um aumento de praticamente $100 \%$ em relação ao exame citológico. Como é de conhecimento, a maioria das infecções por HPV são transitórias, regredindo espontaneamente, sendo a detecção da infecção persistente por HPV de alto risco um passo importante para a prevenção (Walboomers, 1999). O argumento de que o teste de HPV tem menor especificidade do que a citologia o que resulta no aumento da 
realização de colposcopias com consequentes tratamentos desnecessários é usado com frequência apesar do elevado valor preditivo negativo do teste molecular para NIC 3+, em nosso estudo 100\% (Wentzensen et al, 2015).

A triagem das amostras HPV positivas tem sido largamente defendida, normalmente envolvendo a citologia e eliminando diretamente no rastreio primário os casos HPVs negativos, os quais virtualmente não aumentam o risco da ocorrência de lesões de pré neoplásicas e câncer. Ensaios de controles randomizados tem mostrado repetidamente que o teste de HPV detecta precocemente lesões de alto grau persistentes comparadas à citologia e apresentam maior eficiência em prevenir o câncer cervical (Ronco et al., 2014). Entretanto encaminhar todas mulheres HPV positivas para a colposcopia resulta num grande aumento no número de colposcopias necessárias para detectar lesões pré neoplásicas. Portanto, métodos são necessários para selecionar entre as mulheres HPV positivas quais delas tem baixa probabilidade de ter lesões pré neoplásicas detectáveis colposcopicamente evitando os respectivos encaminhamentos imediatos. Estabelecer qual a melhor estratégia para as mulheres que são HPV positivas seguidas de citologia negativa é uma questão que continua a ser discutida, por exemplo quanto ao intervalo de tempo para a realização de um novo exame. Estudo holândes reportou um risco de 5\% para NIC 3+ em mulheres com idade de 30 a 60 anos que apresentaram citologia negativa com teste de HPV positivo, com esse risco tendo um decréscimo para $<1 \%$ se realizada uma citologia após 6 a 12 meses, o que parece aceitável quando considerado o risco para NIC 3+ (Rijkaart et al., 2012).

Nosso estudo procurou também avaliar diferentes alternativas para uma melhor gestão das mulheres com infecções pelo HPV, ajudando a reduzir o número de visitas à clínica, remover etapas desnecessárias na confirmação do diagnóstico, desta 
forma podendo contribuir com projeções futuras no processo de prevenção deste tipo de câncer e redução de custos do programa, como abordado a seguir.

\subsection{Comparação de estratégias (algoritmos) de rastreio do câncer de colo do útero incorporando diferentes combinações de citologia, teste de hpv e genotipagem para os HPVS 16 e 18.}

Os dados gerados nos fornecem a oportunidade de avaliar os benefícios e perdas que seriam produzidos durante uma única visita para realização da prevenção do câncer cervical com diferentes modelos de estratégias: combinações da citologia, teste de HPV e genotipagem para os HPVs 16 e 18.

A estratégia ideal de rastreio do câncer de colo do útero deve combinar a máxima sensibilidade e especificidade para a detecção de NIC 2+, minimizando as taxas de resultados falso negativos e procedimentos desnecessários. Estudos mundo afora tem buscado esse equilíbrio, ponderando os benefícios de diferentes estratégias ao avaliar-se o número total de colposcopias realizadas como medida de detecção de dano. (Cox et al., 2013).

A eficiência de cada estratégia pode ser estimada determinando-se o número de colposcopias requeridas para detectar um único caso de NIC $2+$ ou NIC 3+. A colposcopia tem sido referida como a medida do dano porque demonstra estar associada ao desconforto durante o procedimento, agrega todo efeito psicológico do impacto de uma lesão mais severa e ser a etapa prévia que conduz ao tratamento e biópsia (Cox et al., 2013). Uma análise custo-efetiva completa é essencial para determinar a estratégia a ser escolhida para o rastreio do câncer cervical. As estratégias propostas são possibilidades para o manejo e avaliação do risco em diferentes abordagens. 
A estratégia 1, com o rastreio baseado no teste de HPV isolado e encaminhamento de todas as mulheres HPV positivas para a colposcopia foi mais sensível, mas não parece oferecer o equilíbrio certo entre a máxima detecção de NIC 2+ e NIC 3+, pois resulta em quase duas vezes mais colposcopias do que as outras estratégias. Ao estratificarmos em modelo de rastreio molecular e citológico, observamos uma superioridade de $23,6 \%$ na detecção de NIC $2+$ e $15,4 \%$ na detecção dos casos NIC 3+ quando utilizado o teste de HPV em relação à citologia isolada como método de rastreio (estratégia 2).

As outras estratégias que partem do teste citológico, em combinação com o teste de HPV na forma de coteste (estratégia 3) ou teste reflexo nas citologias ASC-US (estratégia 4) também se mostraram menos sensíveis para detecção de NIC 2+ comparadas ao rastreio molecular. Embora apresentem a mesma sensibilidade comparadas entre si, a estratégia 4 com teste de HPV reflexo para os casos de ASC-US mostrou-se mais eficiente do que a abordagem citológica isolada (estratégia 2) requerendo $67 \%(14,4$ vs 21,3$)$ do total de colposcopias desta estratégia para o mesmo desempenho com ligeiro aumento na especificidade 95,4\% vs 93,1\%. Apesar de requererem um menor número de colposcopias para detectar um caso de NIC $2+$ em relação a estratégia baseada somente em HPV, mostram-se menos atraentes para os clínicos e gestores de saúde, uma vez que aumentam o número de casos de lesões de alto grau não detectados, e no caso do uso do coteste duplicando o número de testes iniciais, o que economicamente pode ser um obstáculo se olharmos para estratégias acima com os mesmos desempenhos.

A baixa sensibilidade dessas estratégias para detecção de NIC 2+, reforça a atenção para os casos que não são identificados no rastreio, dependeriam portanto dos potenciais das estratégias adotadas que propõem acompanhamento em 12 
meses lembrando que estamos falando de um tipo de câncer que os dados reportam elevadas taxas de novos casos ano após ano.

A estratégia 5 a qual é baseada no rastreio molecular reservando a triagem citológica para os casos HPVs positivos vem sendo uma estratégia abordada em diferentes estudos que indicam essa estratégia como mais eficiente quando comparada ao rastreio citológico isolado para detecção de lesões de alto grau (Hebert, 2016). Esta mostrou sensibilidade praticamente igual, com um ligeiro decréscimo em relação às estratégias citológicas $(73,6 \%$ vs $75 \%)$, requerendo um menor número de colposcopias 11,4 vs 21,3 quando comparada à citologia isolada. Uma sensibilidade inferior foi reportada no estudo ATHENA 47,5\% vs 53,2\% para NIC 2+ e 51,9\% vs 57,7\% para NIC 3+ quando comparada à citologia isolada (Wright et al, 2012), contrariando os achados de Leinonen et al., (2009) que em um cenário de rastreio organizado, na Finlândia, comparou a performance do teste de HPV com método de rastreio primário versus a citologia convencional e apontou vantagens no uso desta como método de triagem para as amostras HPVs positivas em mulheres com 35 anos ou mais, agregando um decréscimo nos encaminhamentos para a colposcopia e testes de seguimento. Em outra abordagem, embora tenha resultado em um acréscimo de $12 \%$ no número de testes requeridos para o rastreio, a triagem citológica após o teste de HPV como rastreio primário é advogada por Naucler e colaboradores em estudo com 6.257 mulheres na Suécia, onde os autores concluíram que o rastreamento baseado em HPV seguido de triagem citológica e repetição do teste de HPV para as amostras com citologia negativa aumentou em 30\% a sensibilidade para a detecção de lesões NIC 3+, demonstrando ser uma estratégia de rastreio que pode ser viável (Naucler et al., 2009).

Como já mencionado, o cenário atual da prevenção do câncer de colo do útero vem sofrendo avanços ao longo do tempo incorporando novas técnicas e métodos 
adjuvantes ao Papanicolaou. Acompanhando esse movimento do laboratório de citologia (Joste \& Gober-Wilcox, 2013), em um cenário laboratorial de rotina, comumente a leitura citológica irá ser realizada com o conhecimento prévio do resultado do HPV (Bergeron et al, 2015b), e as leituras das amostras HPVs positivas tendem a ter uma maior prevalência de anormalidades citológicas devido a uma leitura mais minuciosa dos citotécnicos e patologistas, como demonstrado em diferentes estudos (Richardson et al., 2015; Wright et al., 2016; Benoy et al., 2011). Esta abordagem pode ser muito apropriada para o Brasil e países com elevadas taxas de câncer cervical e com baixo desempenho e controle de qualidade do exame citológico (Lorenzi et al., 2015). Nosso grupo realizou um estudo nesse contexto com uma subpopulação de nossa casuística envolvendo 2.376 amostras, e observamos que a leitura citológica com prévio conhecimento do HPV detectou mais casos de NIC $2+$ quando comparada a leitura cega, ou seja, sem o conhecimento prévio do resultado do HPV, sensibilidades de $86,7 \%$ versus $60,0 \%$ respectivamente (dados não publicados). Cabe ressaltar que no presente estudo as leituras citológicas não foram realizadas com o prévio conhecimento do resultado do HPV, o que elevaria as taxas de positividade do exame citológico.

Um maior equilíbrio entre sensibilidade e especificidade pode ser observado nas estratégias 7 e 8, as quais estratificam os genótipos 16 e 18 em relação aos demais HrHPVs reservando a triagem citológica para estes quando positivos. Ambas estratégias apresentaram as melhores perspectivas de benefício vs dano, com menos colposcopias requeridas do que as estratégias citológica e HPV isoladas, e um pequeno aumento no número de colposcopias para detectar uma lesão de alto grau quando comparada às estratégias com menor sensibilidade. A detecção precoce de lesões de alto grau associadas ao HPV 16 foi um dos maiores benefícios da utilização dos testes de HPV 
em estudo realizado na Holanda (Rijkaart et al., 2012) propondo o uso do rastreio baseado em teste de HPV para mulheres com 29 anos ou mais. Em nosso estudo, a presença do HPV 16 foi associado com um grande aumento no risco para NIC 2+, com uma odds ratio de 1.045 em relação as amostras negativas para este genótipo, e um aumento de 4,5 vezes quando comparado as amostras positivas para os outros genótipos de alto risco. Esses achados são reforçados pelo estudo ATHENA, que mostrou um valor preditivo positivo muito mais alto para o HPV 16 em relação aos demais genótipos de alto risco (Wrigth et al., 2012), e entre as estratégias propostas, a genotipagem dos HPVs 16 e 18 e triagem citológica para os demais HrHPVs nos parece ser a mais indicada conforme descrito na literatura (Huh et al., 2015).

Em contrapartida, a utilização do teste de HPV encaminhando os genótipos 16 e 18 diretamente para a colposcopia e acompanhando os demais HrHPVs no seguimento (estratégia 6) apresentou baixa sensibilidade, deixando de detectar 30 casos $(41,7 \%)$ de NIC 2+, inferior à citologia isolada, embora requeira praticamente metade de colposcopias, portanto ao menos para essa população o desempenho não se mostrou atraente, evidenciando a necessidade da triagem citológica para os demais HrHPVs.

Ao compararmos o desempenho da estratégia baseada na citologia versus teste de HPV em nossa casuística de 15.991 mulheres, a citologia isolada não teria detectado pelo menos 18 casos NIC $2+$ classificados como negativos pelo Papanicolaou. Como já mencionado, para o biênio 2016/2017 as estimativas do Inca apontam 16.340 novos de câncer de colo do útero no Brasil. Dado que em nossa casuística foram detectados 4 casos de câncer, se projetarmos para 100 mil mulheres, teríamos 25 casos, dados muito superiores aos 9,5/100 mil mulheres para a capital São Paulo de acordo com as estimativas nacionais. Considerando que se trata de uma população de rastreio, questiona-se o porque de tamanha divergência entre a 
estimativa e o verificado. Extrapolando o número de casos de NIC 2+ com citologia negativa, em nossa casuística foram 18 casos em 16 mil mulheres, permitindo-se projetar uma perda de 112 casos/100.000, e se considerarmos as citologias ASC-US e LSIL que não tem encaminhamento imediato para a colposcopia, essa perda seria de 33 casos, ou seja 206 em 100 mil mulheres. De acordo com a literatura, é esperado uma regressão espontânea de 50-60\% dos casos de NIC 2, que pode variar de acordo com o tempo de acompanhamento (Castle et al., 2009b) mesmo assim diante de uma taxa de regressão de $60 \%$ teríamos ainda 67,2 casos de NIC 2+/100.000 que poderiam não ser detectados e progredir.

Em 2014, foram realizados 9,3 milhões de exames Papanicolau na rede pública de saúde. Para isso, o Ministério da Saúde repassou R\$ 65,5 milhões aos estados e municípios (Portal Brasil, 2015). Numa projeção maior, considerando que o governo brasileiro investe este valor para cerca de 10 milhões de citologias anuais, transpondo nossos achados teríamos uma perda de 7 mil casos classificados como NIC 2+, mesmo com todo valor acima dispendido para a prevenção.

Cabe ressaltar que se tratam de projeções com base nos resultados obtidos neste projeto, nesta população, sem levar em consideração os diferentes índices deste tipo de câncer nas diferentes localidades geográficas de um país continental, podendo sim essas taxas terem variações de acordo com cada região, e até serem mais elevadas se considerarmos localidades como a cidade de Manaus, onde o câncer cervical é o tipo mais incidente naquela população, com uma taxa estimada em 53/100 mil mulheres no ano de 2016 (Inca, 2016).

A citologia não detectou dois casos (15\%) de NIC 3+, projetando proporcionalmente deixaria de identificar 12,5 casos/100 mil mulheres. Como já 
mencionado, citologias com ASC-US não são encaminhadas imediatamente para a colposcopia, e com o corte em citologias > ASC-US, 30,1\% (4/13) dos casos de NIC 3+ não teriam sido referidos pelo Papanicolaou, ou seja 25 casos em 100 mil mulheres. As diretrizes nacionais preconizam o rastreio na faixa etária a partir dos 25 anos, e se a estratégia 10 baseada nas recomendações das diretrizes nacionais que compreende a faixa etária de 25 a 64 anos fosse a adotada, não seriam detectados 4 casos de NIC 2+ com idade inferior aos 25 anos. Uma baixa sensibilidade foi também observada na estratégia 9 que perderia 47,2\% (34/72) casos de NIC 2+ embora requeira os menores números de colposcopias para detecção de lesões de alto grau, não parecendo ser uma estratégia eficaz devido a baixa sensibilidade, $20 \%$ inferior ao rastreio com o corte em ASC-US.

Outros países decidiram restringir o teste de HPV para mulheres com 30 anos ou mais. Acreditamos que esta alternativa não seja aplicável para o cenário brasileiro, onde as diretrizes nacionais recomendam que o rastreio seja iniciado a partir dos 25 anos, embora este serviço não seja negado às mulheres mais jovens que queiram ser examinadas. Além disso, mulheres com menos de 30 anos se beneficiariam do uso do teste molecular, conforme este estudo evidenciou.

Neste estudo 36\% (26/72) dos casos de NIC 2+ foram identificados nas mulheres com menos de 30 anos, enquanto NIC 3+ representou 15,4\% (2/13) neste grupo etário. Já é bem conhecida que a citologia é menos sensível para detectar lesões glandulares, em nossa casuística tivemos um caso de adenocarcinoma detectado pelo teste de HPV com citologia negativa, o que corrobora os achados de Ronco e colaboradores (2014) que endossam a maior sensibilidade do teste molecular para detectar lesão glandular comparada ao rastreio citológico, demonstrando que o uso do 
teste molecular pode ser um benefício, pois é esperado que o mesmo apresente a mesma sensibilidade para lesões escamosas e glandulares.

Uma outra abordagem que vem sendo muito estudada, seria a utilização de biomarcadores, através de testes imunocitoquímicos, pois como vimos, uma vez que a infecção pelo HPV oncogênico promove a replicação desregulada do genoma do hospedeiro, várias proteínas envolvidas no controle do ciclo celular tem seus níveis de expressão alterados, como por exemplo a p16INK4a, já citada anteriormente no item (2.3.1.3) e a Ki-67 (Kisser, 2015). A utilização de p16 e ki67 tem sido avaliada em grandes estudos de rastreio primário e triagem das mulheres HrHPVs positivas (Ikenberg, H. et al., 2013). Os resultados sugerem que as amostras com dupla coloração positiva devem ser encaminhadas à colposcopia, enquanto as mulheres com resultados negativos podem ser monitoradas em intervalos de rastreio prolongados (Wentzensen et al., 2015; Carozzi et al., 2013). Tem sido observado que a triagem de mulheres HPV positivas com p16 apresenta sensibilidade superior à citologia convencional, com as taxas de encaminhamento para colposcopia comparáveis entre ambas abordagens Carozzi et al., 2013). Cabe destacar que o p16 já é usado de rotina como marcador histológico de lesão como um adjuvante para o diagnóstico de NIC 2, recomendado para a diferenciação dos casos benignos que mimetizam lesões intraepiteliais de alto grau. (Bergeron et al., 2015a). Segue o desafio para encontrar uma triagem adequada para as mulheres HrHPVs positivas, de modo a selecionar aquelas com maior risco de desenvolverem lesões pré cancerosas e portanto necessitando de colposcopia imediata. A dupla coloração p16/Ki-67 apresenta-se como opção atraente, possibilidade de realização na mesma amostra (sem coleta adicional), sendo necessários mais estudos antes da adesão na rotina laboratorial (Bergeron, 2016). 
Outra alternativa que utiliza o teste de HPV; a auto coleta vaginal (mulheres coletam o próprio material) apresenta de modo geral igual ou maior sensibilidade do que a citologia obtida pela coleta de profissionais de saúde para a detecção de NIC $2+$, e pode ser uma excelente alternativa, pela facilidade de obtenção do material, como rastreio primário acoplada ao teste molecular (Snijders et al., 2013), principalmente para mulheres com acesso limitado ao rastreamento tradicional pelo método de Papanicolaou particularmente em locais com recursos humanos e tecnológicos escassos (LazcanoPonce, et al., 2014).

Vale ressaltar que as mudanças na implementação de novos testes e algoritmos, vão além das questões técnicas. Há uma preocupação em relação as mulheres no recebimento de um resultado de HPV positivo. As reações incluem confusão e ansiedade, associação com DST, fidelidade nos relacionamentos e questões religiosas devido a via sexual ser a forma mais comum de transmissão. Nota-se que a compreensão pública ficou atrás dos avanços científicos e técnicos, fazendo-se necessário a necessidade da educação dos profissionais de saúde e população (Cuzick et al., 2006).

No futuro, com grande parte da população vacinada, é esperada uma queda no número de casos de câncer cervical e suas lesões precursoras, tornando menos frequente as alterações morfológicas encontradas na citologia. Por apresentar uma sensibilidade maior em relação ao exame citológico, é possível que o teste ideal para rastreamento passe a ser o teste molecular (Almonte et al., 2011; Tota et al., 2014). A FOSP realiza aproximadamente 1.000 citologias/dia e possui uma equipe de 28 citotécnicos e 5 patologistas. Com um "troughput” em média de 90 amostras/dia, uma plataforma Viper é insuficiente para atender esta demanda, sendo necessário algo em torno de 10 equipamentos, ao contrário de outros plataformas automatizadas com maior capacidade 
de realização de testes diários (cerca de 270 amostras/dia) como o Cobas 4800® (Roche, USA) que demandaria um menor número de equipamentos para contemplar a rotina diária, além de um menor número de profissionais requeridos em ambos testes automatizados quando comparados à citologia oncótica.

Um aumento nos custos previstos nas análises por técnicas moleculares pode ser compensado por um intervalo maior no rastreio do câncer cervical, além da redução de custos dos procedimentos para seguimento das lesões pré-neoplásicas (NIC2+) e neoplásicas do colo uterino, como excisões cirúrgicas, crioterapia, radioterapia e/ou quimioterapia, portanto, podendo ter um impacto positivo em relação ao custo benefício (Berkhof et al., 2010). A análise de custo-efetividade nas condições deste estudo na rede pública paulistana está sendo realizada atualmente para determinar o algoritmo de rastreio ideal para a o câncer de colo do útero usando o teste HrHPV e/ou citologia, genotipagem do HPV e futuramente poderemos incluir questões como intervalo da realização dos exames, idade de início e acompanhamento eficaz das mulheres com teste HrHPV positivo.

O progresso no conhecimento médico e tecnológico é acompanhado por uma evolução natural para intervenções mais eficazes e melhores cuidados ao paciente. O movimento do teste de Papanicolaou, passando pela citologia em meio líquido, leitura guiada por computador e para o teste de HrHPV é apenas parte dessa progressão natural. Entretanto, há uma grande resistência, entre muitas razões, o Papanicolaou foi e continua sendo um dos testes laboratoriais clínicos mais comuns e consagrados devido a sua grande contribuição na redução dos casos de câncer cervical.

Outros ensaios de diagnóstico não são diferentes, e muitos exemplos estão disponíveis: mudanças da creatina quinase para troponina nos diagnósticos de infarto do miocárdio; desde a glicose até à hemoglobina A1c, para o diagnóstico e monitorização 
do diabetes (Castle 2015), e também podemos exemplificar os bancos de sangue que utilizam os testes moleculares para HIV, HCV e HBV sem deixar de realizar os testes sorológicos.

Destaca-se que quando falamos em rastreio, temos que levar em conta alguns aspectos fundamentais, pois não se trata apenas em considerar o teste a ser empregado, mas também a educação tanto da população atendida quanto do profissional envolvido no rastreio; a ampla cobertura da população; e após, o tratamento e o devido seguimento das mulheres. Sem esses pontos interligados dificilmente conseguiremos um manejo adequado e consequentemente muitas mulheres continuarão morrendo por câncer do colo do útero.

Seguem em andamento estudos de custo-efetividade, aspectos da aquisição, persistência e carcinogênese por HPVs, elaboração de novos algoritmos (faixa etária, métodos, seguimento, tratamento) com o intuito de desenvolver melhores estratégias de prevenção e tratamento das infecções e doenças causadas por estes vírus. 


\section{Conclusões}


A efetividade do diagnóstico precoce para a prevenção do câncer do colo do útero, e a diminuição da mortalidade por este agravo se mantêm como um desafio para o Sistema Único de Saúde do Brasil, que apresenta ainda altas taxas de mortalidade. Nossos achados apontam que o uso de rastreio assistido por computador na rotina diária pode ser uma medida importante para a redução de resultados falso-negativos. O teste de HPV detectou um número significativo de pacientes com lesões pré-malignas não detectadas pela citologia. Ainda, a citologia forneceu uma classificação que de acordo com o algoritmo atual, atrasa a detecção de NIC2 + devido a um ciclo de citologia repetida em 6 meses - 1 ano. Se for adotado o rastreamento de DNA de HPV, de modo a evitar um aumento na necessidade de exames colposcópicos, será muito importante adicionar um marcador de valor preditivo positivo elevado às amostras de HPVs + antes de referir à colposcopia.

O critério adotado para os países Europeus, com a utilização dos testes de HPV em mulheres acima de 30 anos não parece ser o ideal para o Brasil, devido a alta incidência de lesão de alto grau neste grupo. O uso da genotipagem 16/18 e triagem citológica para os demais HrHPVs forneceu o melhor equilíbrio entre sensibilidade e especificidade, número de testes e colposcopias requeridas para detecção de NIC 2+, e pode ser uma alternativa de uso combinado dos dois testes.A despeito dos esforços do governo para melhorar as taxas de cobertura do exame de Papanicolaou, as taxas de incidência e mortalidade pela doença permanecem elevadas e o diagnóstico continua tardio. Consideramos que o estado de São Paulo possa ser pioneiro em uma mudança nos métodos de rastreamento, o que pode proporcionar uma redução substancial na incidência e mortalidade por câncer cervical no Brasil, em última análise, uma doença evitável e podendo esta ser uma alternativa economicamente viável. Paralelo a este estudo, uma análise de custo efetividade está sendo realizada, uma vez 
que os testes, quando são utilizados em larga escala, levam a uma redução dos preços, a exemplo da Rede de Carga Viral para HIV que iniciou com testes custando \$ 120 dólares e que hoje custam $\$ 10$ dólares. A existência de diferentes plataformas e fornecedores também estimula a competição e favorece a queda dos valores dos testes.

É importante reconhecer que objetivo do rastreio é prevenir o câncer cervical, reconhecendo e tratando lesões precursoras antes de evoluírem para o câncer. Fazendo isto com efetividade e evitando procedimentos e tratamentos excessivos alcançaremos o objetivo principal do rastreio do câncer cervical. Nesta tese, apresentamos uma prova de que o rastreio baseado em testes de HPV detecta lesões clinicamente relevantes (NIC 2+) não detectadas pela citologia. Uma vez que essas lesões podem progredir para o câncer cervical, a detecção precoce reduziria os casos deste tipo de câncer e permitiria a intervenção precoce. A vacinação pode levar a uma piora do diagnóstico citológico pela raridade dos achados (diminuição de lesões), desta forma uma ferramenta diagnóstica mais sensível e não subjetiva como a biologia molecular se torna atraente. A implantação na rede pública é viável mas necessita uma análise de custo-efetividade, podendo esta medida além de salvar vidas gerar economia para o Sistema Único de Saúde.

\subsection{Sumário dos resultados}

- $\quad$ Como verificado em diferentes estudos mundo afora, o rastreio baseado em teste de HPV é mais sensível do que a citologia;

- A inclusão da citologia em meio líquido facilita todo processo de coleta, transporte, armazenamento e leitura associada ao uso de computador; além de permitir a associação com testes moleculares; 
- $\quad$ O Focalpoint classificou os dois casos de carcinoma no quintil 1 (Q1) e aproximadamente $90 \%$ dos casos de HSIL e $80 \%$ das citologias classificadas como ASC-H nos Q1 e Q2 respectivamente;

- A prevalência de HrHPV encontrada neste estudo (15\%) é similar a outros estudos conduzidos no Brasil;

- A sensibilidade do teste de HrHPV foi 23,6\% superior ao teste citológico para detecção de NIC 2+;

- $\quad$ A citologia isolada não detectou 18 casos de NIC 2+ classificados como negativos;

- O uso da genotipagem 16/18 e triagem citológica para os demais HrHPVs forneceu um equilíbrio entre sensibilidade e especificidade, número de testes e colposcopias requeridas para detecção de NIC 2+,

\subsection{Perspectivas}

- Implantação na Rede Pública de Saúde da Citologia em base líquida, possivelmente seguida futuramente dos testes de HPV;

- $\quad$ Algoritmo com genotipagem dos HPVs 16 e 18 reservando a citologia as amostras com os demais HrHPVs;

- $\quad$ Adição de um biomarcador com elevado valor preditivo positivo de modo a identificar as mulheres com maiores chances de progredirem para lesões mais severas e evitar procedimentos desnecessários;

- Ampliar a amostragem, com inclusão de amostras das diversas regiões do Estado, para que possa refletir a epidemiologia da infecção pelo HPV no 
estado de São Paulo e determinação genotípica de modo também a avaliar a proteção vacinal.

\subsection{Partipação do aluno e produção científica}

O aluno esteve envolvido em todas as etapas do estudo. Possui formação em citopatologia cervical, tendo atuado por vários anos como profissional do setor. Recebeu treinamento em citologia líquida (BD SurePath), acompanhou a realização dos testes moleculares, além de trabalhar junto a equipe da FOSP nos treinamentos nas UBSs, revisão de lâminas, tabulação e armazenamento dos resultados e das análises dos mesmos. $\quad$ O Anexo 6 apresenta a produção científica do aluno relacionada a tese. 
8. Anexos 
Anexo 1- Termo de Consentimento Livre e Esclarecido

\title{
Termo de Consentimento Livre e Esclarecido
}

\begin{abstract}
Título: "Citologia líquida e teste molecular para HPV de alto risco: avaliação de novas modalidades de rastreio para prevenção de câncer de colo uterino na Rede Pública de Saúde do Estado de São Paulo."
\end{abstract}

Você está sendo convidada para participar de uma pesquisa. Obrigado pelo seu interesse.

Por favor, leia este termo de consentimento ou peça que alguém o leia para você.

A Fundação Oncocentro da Secretaria de Estado da Saúde de São Paulo (FOSP) em parceria com a Faculdade de Medicina da USP e o Instituto do HPV (Santa Casa de São Paulo) está realizando uma pesquisa para avaliar uma nova forma de conservar e de processar a amostra para o exame de Papanicolaou.

A FOSP realiza cerca de 250 mil exames de Papanicolaou por ano. Esse exame é feito com uma amostra de células da superfície do colo do útero, verificando se há alterações que surgem antes do câncer.

Cerca de 16.000 mulheres usuárias de serviços de saúde de duas regiões da cidade de São Paulo participarão deste estudo. O pesquisador responsável por este estudo é o Prof. Dr. José Eluf Neto da Fundação Oncocentro e da Faculdade de Medicina da USP.

A Becton, Dickinson and Company Diagnostics (BD Diagnostics) é responsável pelos custos do estudo.

Essa pesquisa e esse termo de consentimento foram avaliados e aprovados pelo Comitê de Ética em Pesquisa - CEP da Faculdade de Medicina da Universidade de São Paulo.

\section{Este estudo avalia uma nova forma de conservar e processar a amostra para o exame de} Papanicolaou.

A principal causa do câncer de colo uterino é a infecção pelo papilomavírus humano, mais conhecido como HPV. Esse vírus é transmitido na maioria das vezes através da relação sexual. Em algumas mulheres a infecção pelo HPV provoca alterações nas células do colo do útero que podem evoluir para câncer do colo uterino se não forem tratadas.

O exame de Papanicolaou é considerado um exame preventivo para o câncer do colo uterino, pois identifica as alterações que antecedem o câncer permitindo que elas sejam tratadas.

Esse exame vem sendo utilizado há mais de 50 anos em todo o mundo e é fundamental para reduzir os casos de câncer do colo uterino. No Brasil, este tipo de câncer continua sendo muito freqüente.

A coleta deste exame é rápida e realizada com espátula e escovinha e, para a maioria das mulheres não causa qualquer desconforto ou dor. Após a coleta é feito um preparo para que o laboratório possa verificar se existem ou não alterações nas células.

A forma convencional de preparar o material colhido do colo do útero é esfregando a espátula e a escovinha numa lâmina de vidro. Um líquido é aplicado na lâmina para fixar o material que é então encaminhado para o laboratório. As lâminas receberão corantes e serão analisadas num microscópio.

Há alguns anos foi desenvolvida, testada e aprovada uma nova técnica chamada: coleta em meio líquido. Após a coleta, a escovinha é mergulhada dentro de um frasco contendo um líquido conservante. O frasco é fechado e encaminhado para o laboratório. As células ficam dispersas no líquido e um equipamento prepara a lâmina antes da leitura no microscópio. Essa técnica diminui os problemas na coleta e no preparo das lâminas facilitando a leitura e consequentemente o diagnóstico. Tem sido muito usada em vários países. No Brasil também é utilizada por alguns laboratórios.

Além de diminuir alguns dos problemas apresentados pela técnica convencional, com essa técnica é possível no mesmo material, verificar a presença do HPV. 
Este estudo tem como objetivos:

- $\quad$ Avaliar a utilização da coleta em meio líquido em unidades de saúde no Estado de São Paulo;

- $\quad$ Avaliar o exame para o HPV realizado a partir da coleta em meio líquido;

- Fornecer informações para a construção de um novo modelo para implantação no programa de detecção de câncer de colo uterino no Estado de São Paulo.

\section{Você escolhe se quer ou não participar do estudo.}

A sua decisão de entrar para esta pesquisa é voluntária. Seu atendimento nesta unidade de saúde não será afetado e você não perderá quaisquer benefícios ou direitos que normalmente teria caso se recuse a participar desta pesquisa.

\section{Procedimentos que serão realizados na pesquisa.}

Após a leitura deste termo de consentimento você poderá tirar dúvidas e esclarecer qualquer questão relacionada à sua participação na pesquisa.

Se decidir participar, pediremos que assine duas vias deste documento. Você receberá uma via para guardar e a outra via será arquivada em local seguro. O profissional responsável pelos procedimentos do estudo também irá assinar as duas vias do documento.

Após a assinatura será preenchido o formulário de "Requisição de Exame Citopatológico - Colo do Útero". As informações são exatamente as mesmas que seriam colhidas se você estivesse fazendo seu exame de forma rotineira e não estivesse participando desta pesquisa. Não será colhida qualquer informação adicional.

A seguir será realizada a coleta do exame de Papanicolaou. Os procedimentos para a coleta são exatamente iguais aos realizados numa coleta rotineira deste exame. Não há nenhuma diferença na maneira como o exame é colhido para esta pesquisa.

Após a coleta, o material será mergulhado em meio líquido e sua amostra será encaminhada ao laboratório para análise.

Será realizada a análise para verificar a presença de alterações das células do colo do útero. Esses procedimentos năo diferem dos que são realizados na forma convencional de processar e preparar a amostra.

Nesta pesquisa também será realizado o teste para o HPV na sua amostra.

Será agendada uma consulta de retorno para você receber seus resultados. Você será orientada e a partir desses resultados poderão ser pedidos exames adicionais tais como colposcopia e biópsia. Esses exames adicionais também farão parte dos resultados deste estudo.

É muito importante que você retorne para receber seus resultados. Lembre-se que antes do aparecimento do câncer de colo uterino aparecem alterações nas células que podem ser detectadas no exame de Papanicolaou. Essas alterações podem ser tratadas antes que o câncer se desenvolva.

\section{Desconfortos e riscos possiveis.}

A coleta de rotina do exame de Papanicolaou pode trazer algum constrangimento, preocupação ou até certo desconforto para você. $\mathrm{O}$ exame não causa dor para a maioria das mulheres. Converse com o profissional responsável pela coleta se você se sentir desconfortável. Ele fará o possível para que o exame seja colhido com o mínimo de desconforto.

Os resultados também podem trazer preocupação a você. Você será orientada e exames adicionais poderão ser solicitados. Faça todas as perguntas necessárias para esclarecer suas dúvidas. 


\section{Benefícios.}

É possível que sua participação neste estudo não the traga nenhum benefício. Porém, participando desta pesquisa você estará contribuindo para novos conhecimentos em relação ao câncer de colo uterino e para que as ações de prevenção desta doença sejam melhor aplicadas.

Se a pesquisa com sua amostra levar a uma nova descoberta você não receberá qualquer benefício financeiro por isso.

\section{Confidencialidade dos dados de pesquisa.}

Os documentos de pesquisa serão arquivados em local seguro. Somente os profissionais envolvidos terão acesso aos documentos e são responsáveis por manter a confidencialidade, o sigilo dos dados e garantir a sua privacidade.

Os resultados deste estudo podem ser publicados. Em nenhuma publicação usaremos seu nome ou o identificaremos pessoalmente.

\section{Uso da amostra.}

A amostra de células do seu colo uterino colhida para esta pesquisa somente será utilizada para os procedimentos descritos neste documento. Qualquer outro estudo que venha a ser feito com sua amostra armazenada só será realizado após a análise e aprovação de um Comitê de Ética em Pesquisa.

Todas as amostras deste estudo ficarão armazenadas na FOSP por pelo menos 5 anos.

Sua amostra não será cedida ou comercializada.

\section{Despesas decorrentes da participação na pesquisa.}

Você não receberá nenhum pagamento para participar desta pesquisa.

Você não terá que pagar nada para participar. Isso significa que nenhum procedimento ou exame relacionado a este estudo serão cobrados. Não há nenhuma despesa decorrente de sua participação nesta pesquisa.

\section{Dúvidas ou problemas.}

Se tiver alguma pergunta sobre este estudo, entre em contato com o Prof. Dr. José Eluf Neto no telefone 1137971802 ou através do email presidência@fosp.saude.sp.gov.br

Se tiver alguma dúvida sobre seus direitos como participante da pesquisa, problemas ou preocupação com o modo como está sendo tratada neste estudo, ou denúncias éticas entre em contato com o Comitê de Ética em Pesquisa (CEP) Av. Dr. Arnaldo, 455 - Instituto Oscar Freire - 1º andar - tel: 3061-8004 - fax: 3061-8004 - email: cep.fmusp@hcnet.usp.br e/ou com o CEP da Secretaria Municipal de Saúde de São Paulo - tel: 3397-2464 e-mail: smscep@gmail.com

\section{Assinaturas.}

Antes de assinar este termo de consentimento, certifique-se de que você:

- Leu este termo de consentimento, ou que alguém o tenha lido para você.

- O estudo foi explicado a você.

-Suas perguntas foram respondidas.

-Entendeu que poderá fazer perguntas a qualquer hora.

-Rubricou todas as páginas.

-Concordou em participar deste estudo.

Página 3 de 4

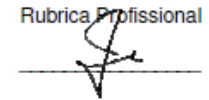


Você não estará desistindo de nenhum dos seus direitos ao assinar este termo de consentimento.
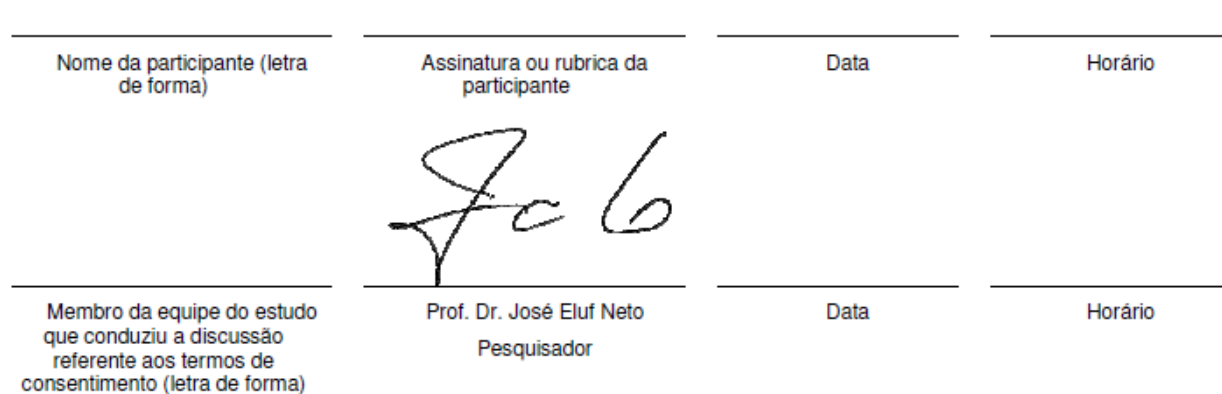
rentente aos termos de

Pesquisador

Data

Horário

Para participantes que não possam ler ou escrever, complete também o bloco de assinatura abaixo para a testemunha. (A testemunha deve ser imparcial: alguém que não faça parte ou esteja relacionado ao estudo e que esteve presente durante o processo de consentimento).

Nome da testemunha (letra
de forma)

Se a participante deseja dispensar a testemunha, a impressão digital está autorizada, inclusive para deficientes visuais

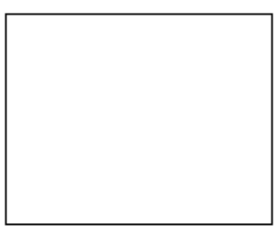

Página 4 de 4

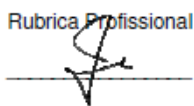


Anexo 2- $\quad$ Dados da população-alvo

O anexo mostra os resultados do rastreio citológico no ano de 2011 (Janeiro a Novembro) nas unidades que participaram do estudo.

\begin{tabular}{|c|c|c|c|c|c|c|c|c|c|c|c|c|c|c|}
\hline & & \multicolumn{6}{|c|}{ Unidades de Saúde: Total / Satisfatórios e Alterados } & \multicolumn{7}{|c|}{ Período:Jan-Nov/2011 } \\
\hline Unidade de saúde & Satisf. & ASC-US & ASC - H & AGUS & AGUS-H & \begin{tabular}{|c|} 
Células \\
Atípicas de \\
origem \\
indefinida \\
Indetermin \\
adas \\
possivelm \\
ente Não \\
Neo \\
\end{tabular} & \begin{tabular}{|c|} 
Células \\
Atípicas de \\
origem \\
indefinida \\
Indetermin \\
adas Não \\
se pode \\
Afastar Alto \\
Grau
\end{tabular} & LSIL & HSIL & \begin{tabular}{|l|} 
HSIL (não \\
podendo- \\
se excluir \\
invasão)
\end{tabular} & CEC & $\begin{array}{c}\text { ADENO CA "in } \\
\text { situ" }\end{array}$ & ADENO CA & $\begin{array}{c}\text { Total } \\
\text { alterados }\end{array}$ \\
\hline 2787210 UBS J BOA VISTA & 1028 & 15 & 7 & 1 & 1 & 0 & 0 & 15 & 3 & 0 & 0 & 0 & 0 & 42 \\
\hline 2788217 UBS PAULO VI & 1764 & 32 & 8 & 2 & 1 & 0 & 0 & 16 & 8 & 0 & 0 & 0 & 0 & 67 \\
\hline 2788810 UBS V.DALVA & 1040 & 31 & 8 & 1 & 1 & 0 & 0 & 10 & 1 & 1 & 1 & 0 & 0 & 54 \\
\hline 2787326 UBS J D ABRIL & 798 & 15 & 1 & 0 & 1 & 0 & 0 & 14 & 5 & 0 & 0 & 0 & 0 & 36 \\
\hline 2787784 UBS J. SÃO JORGE & 1370 & 25 & 10 & 1 & 1 & 0 & 1 & 24 & 4 & 1 & 0 & 0 & 0 & 67 \\
\hline 2789256 UBS V. SONIA & 2014 & 51 & 16 & 5 & 4 & 1 & 3 & 32 & 9 & 0 & 1 & 0 & 0 & 122 \\
\hline Total Projeto Região Oeste & 8014 & 169 & 50 & 10 & 9 & 1 & 4 & 111 & 30 & 2 & 2 & 0 & 0 & 388 \\
\hline $\begin{array}{l}2065665 \text { Hosp/Mat. } \\
\text { INTERLAGOS }\end{array}$ & 8251 & 186 & 49 & 19 & 15 & 1 & 0 & 96 & 24 & 1 & 1 & 0 & 1 & 393 \\
\hline TOTAL GERAL & 16265 & 355 & 99 & 29 & 24 & 2 & 4 & 207 & 54 & 3 & 3 & 0 & 1 & 781 \\
\hline
\end{tabular}


Anexo 3- $\quad$ Nota explicativa incluída para as mulheres com resultados positivos para o teste do HPV

\section{Exame de Papanicolaou e Pesquisa de HPV}

O câncer do colo do útero é uma doença de evolução lenta que depende da infecção persistente pelo HPV (papilomavírus humano) por vários anos. Se forem diagnosticadas suas formas precursoras (lesões intraepiteliais) ou o câncer em fase inicial, é uma doença que pode ser curada. Nestas fases iniciais da doença, a mulher não sente nada e, por isso, deve realizar exames de rastreamento, como o exame de Papanicolaou.

Como a infecção pelo HPV é responsável pelo desenvolvimento do câncer de colo uterino, sua identificação também pode auxiliar no rastreamento e prevenção deste tipo de câncer.

O HPV é um vírus que passa de uma pessoa para outra, principalmente por relação sexual. A contaminação pode ocorrer em qualquer período da vida, em relacionamentos recentes ou de muitos anos atrás.

Existem os HPV de baixo e de alto risco, e o exame que você fez pesquisou apenas os HPV de alto risco que causam o câncer de colo uterino. No entanto, ter resultado positivo para HPV de alto risco não significa ter câncer, pois a maioria das mulheres, principalmente as com menos de 25 anos elimina o vírus naturalmente, sem tratamento.

Portanto, se seu resultado de Papanicolaou for negativo, mas a pesquisa de HPV for positiva, a conduta dependerá da sua idade:

- Se você tiver 25 anos ou mais será encaminhada para colposcopia, que é um exame complementar onde o médico avaliará se há, ou não, necessidade de outros exames e de tratamento.

- Se você tiver menos de 25 anos o teste para HPV e o Papanicolaou serão repetidos em 1 ano.

Em ambos os casos é muito importante cumprir as orientações dos profissionais da saúde. 
Anexo 4- Nomenclatura brasileira para laudos cervicais

\section{TIPO DE AMOSTRA}

- Esfregaço convencional (Papanicolaou)

- Citologia em meio líquido

\section{ADEQUAÇÃO DA AMOSTRA}

- Satisfatória para avaliação

- Insatisfatório para avaliação... (especificar o motivo)

Epitélios representados na amostra:

- Escamoso

- Glandular

- Metaplásico

\section{DIAGNÓSTICO DESCRITIVO}

- Dentro dos limites da normalidade, no material examinado;

- Alterações celulares benignas;

- Atipias celulares.

\section{Alterações celulares benignas}

- Inflamação

- Reparação

- Metaplasia escamosa imatura

- Atrofia com inflamação

- Radiação

- Outras (especificar)

\section{Atipias celulares}

- Células atípicas de significado indeterminado:

- Escamosas:

- Possivelmente não-neoplásicas;

- Não se pode afastar lesão intra-epitelial de alto grau.

- Glandulares:

- Possivelmente não-neoplásicas;

- Não se pode afastar lesão intra-epitelial de alto grau.

- De origem indefinida:

- Possivelmente não-neoplásicas;

- Não se pode afastar lesão intra-epitelial de alto grau. 


\section{Em células escamosas:}

- Lesão intra-epitelial de baixo grau (compreendendo efeito citopático pelo HPV e neoplasia intra-epitelial cervical grau I);

- Lesão intra-epitelial de alto grau (compreendendo neoplasias intra-epiteliais cervicais graus II e III);

- Lesão intra-epitelial de alto grau, não podendo excluir microinvasão;

- Carcinoma epidermóide invasor

\section{Em células glandulares:}

- Adenocarcinoma in situ

- Adenocarcinoma invasor: Cervical

\section{Endometrial}

Sem outras especificações

\section{MICROBIOLOGIA}

- Lactobacillus sp;

- Bacilos supracitoplasmáticos (sugestivos de Gardnerella/Mobiluncus);

- Outros bacilos;

- Cocos;

- Candida sp;

- Trichomonas vaginalis;

- Sugestivo de Chlamydia sp;

- Actinomyces sp;

- Efeito citopático compatível com vírus do grupo Herpes;

- Outros (especificar). 
Anexo 5- Requisição de Exame Citopatológico - Colo do Útero

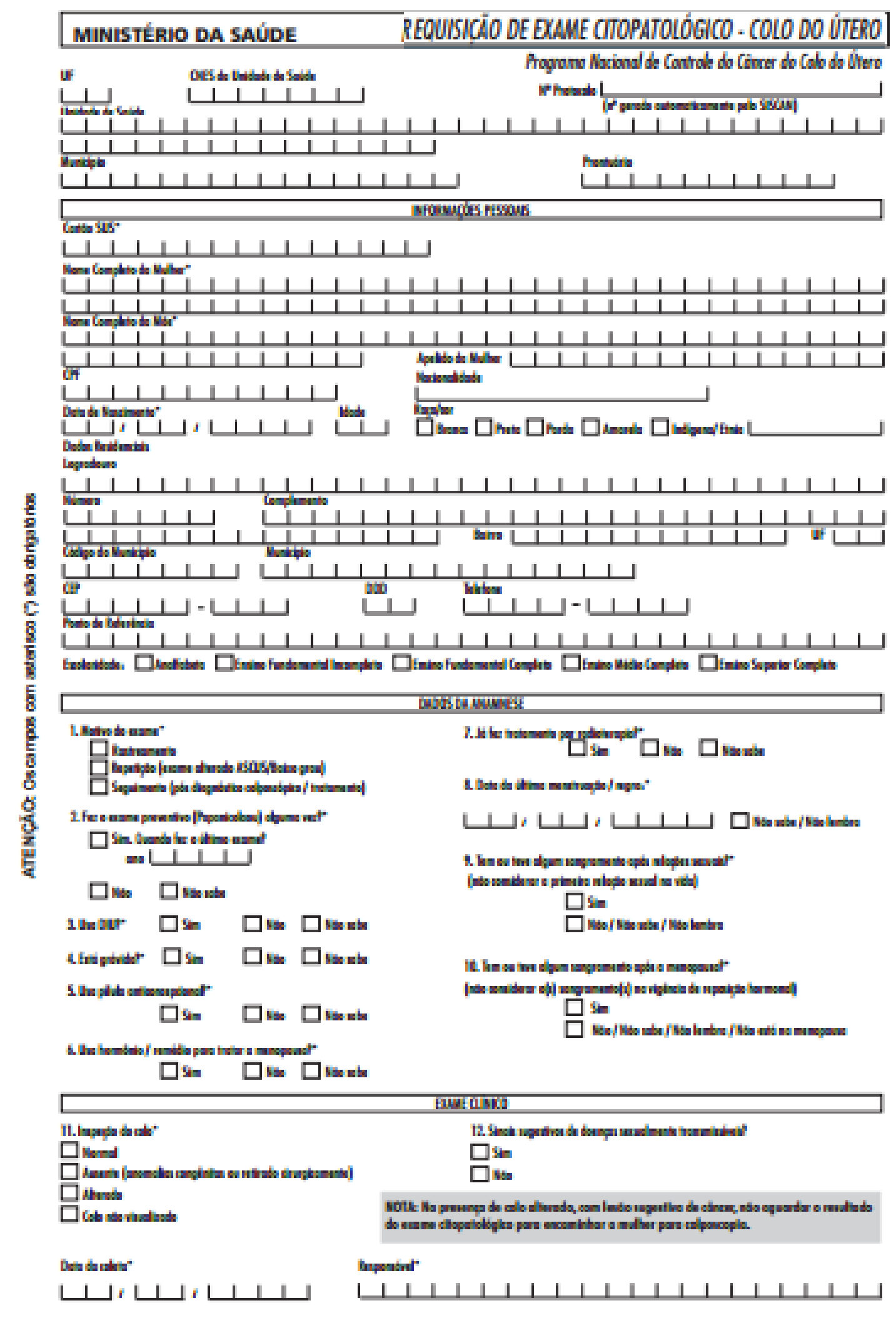




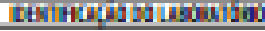

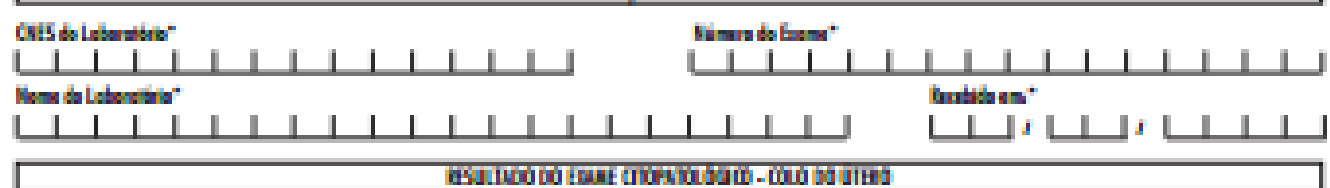

\begin{tabular}{|c|c|}
\hline muncio rel-awatina & \multirow{9}{*}{ 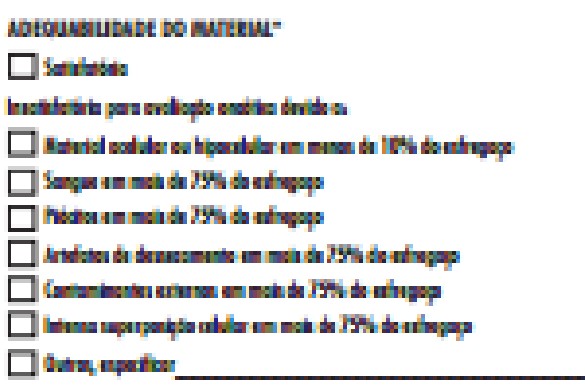 } \\
\hline vasha ieftearte. & \\
\hline 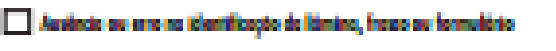 & \\
\hline 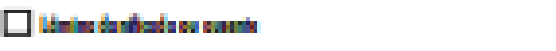 & \\
\hline 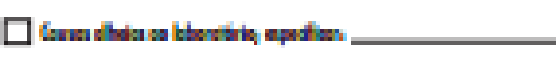 & \\
\hline D wha wasn wathen & \\
\hline Entenas erreseruces mu moste. & \\
\hline 口trason & \\
\hline$\square$ Glandur & \\
\hline \multicolumn{2}{|l|}{$\square$ Anteplatex } \\
\hline \multicolumn{2}{|l|}{ aucabsico tecaitros } \\
\hline \multirow{2}{*}{ 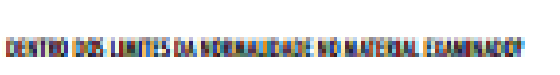 } & 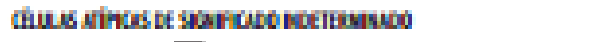 \\
\hline & 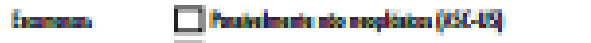 \\
\hline$\square^{\operatorname{sm}} \quad \square^{m}$ & 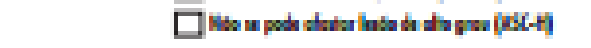 \\
\hline \multicolumn{2}{|l|}{ 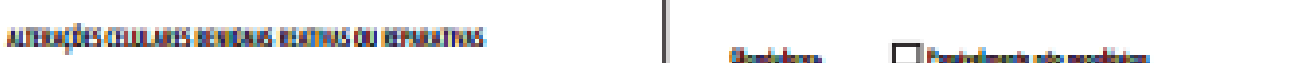 } \\
\hline Qullomate & 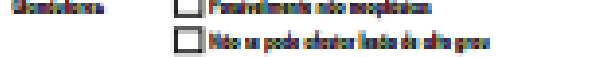 \\
\hline \multicolumn{2}{|l|}{ 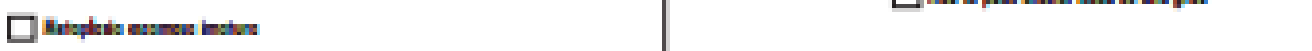 } \\
\hline$\square$ kepenqua & 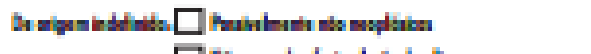 \\
\hline \multicolumn{2}{|r|}{ 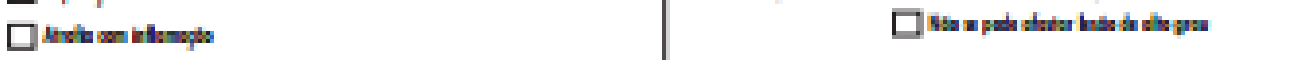 } \\
\hline \multicolumn{2}{|l|}{$\square^{\text {tothops }} \quad-$} \\
\hline \multicolumn{2}{|r|}{ 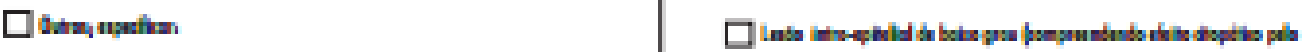 } \\
\hline \multicolumn{2}{|r|}{ 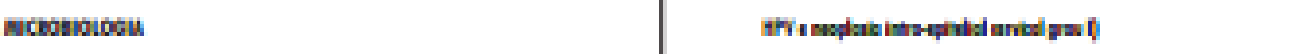 } \\
\hline \multicolumn{2}{|r|}{ 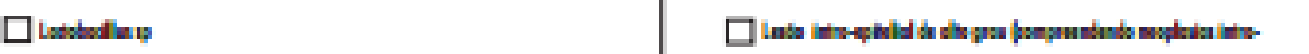 } \\
\hline \multicolumn{2}{|r|}{ 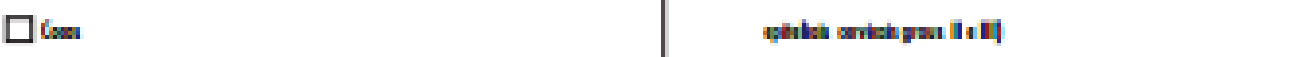 } \\
\hline \multicolumn{2}{|r|}{ 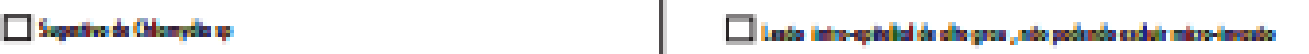 } \\
\hline \multicolumn{2}{|r|}{ 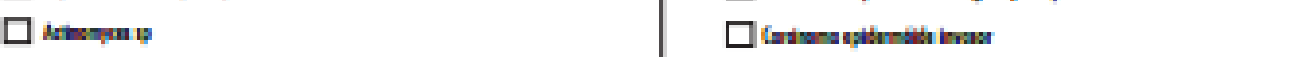 } \\
\hline \multicolumn{2}{|r|}{ arusenchusenstunis } \\
\hline \multicolumn{2}{|r|}{ 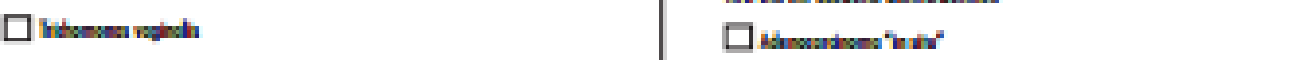 } \\
\hline \multicolumn{2}{|l|}{ 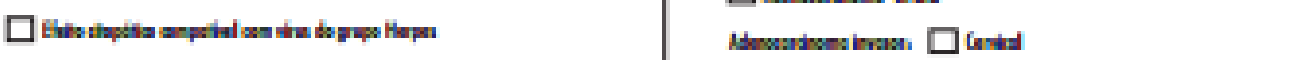 } \\
\hline \multicolumn{2}{|l|}{ 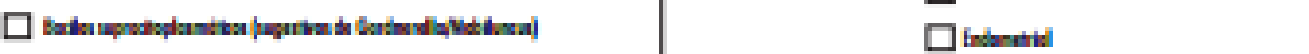 } \\
\hline \multicolumn{2}{|r|}{ 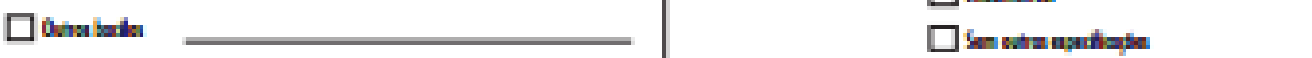 } \\
\hline \multirow[t]{2}{*}{ 口oman enpofan } & $\square$ antes eanusas wusus. \\
\hline & 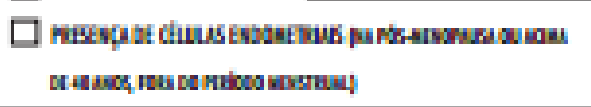 \\
\hline
\end{tabular}

Otourvaple fercta

Sauning ath dowates.

Derabollanatate

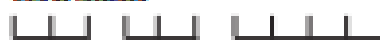

Bepenatur'

J

oft

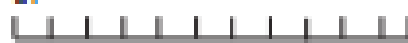


Anexo 6 - $\quad$ Produção científica do aluno relacionada a tese

- Artigos em colaboração publicados

1. Clinical characteristics of women diagnosed with carcinoma who tested positive for cervical and anal high-risk human papillomavirus DNA and E6 RNA

Tumor Biol.

DOI 10.1007/s13277-015-3205-9

RESEARCH ARTICLE

Clinical characteristics of women diagnosed with carcinoma who tested positive for cervical and anal high-risk human papillomavirus DNA and E6 RNA

Carlos A. R. Veo • Sarhan S. Saad - José Humberto T. G. Fregnani • Cristovam Scapulatempo-Neto •

Audrey Tieko Tsunoda · Júlio César Possati Resende - Adriana Tarlá Lorenzi • Allini Mafra • Claudia Cinti · Ismael Dale Cotrim - Luciana Albina Reis Rosa • Cristina Mendes de Oliveira - Toni Ricardo Martins *

Cristiane Centrone · José Eduardo Levi · Adhemar Longatto-Filho

2. Critical Analyses of the Introduction of Liquid-Based Cytology in a Public Health Service of the State of São Paulo, Brazil

Gynecologic Cytopathology

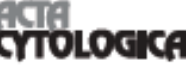

ActaCytobgica $201559: 273-277$

D이: $10.1159 / 000435801$

Receirod: Ipril 23, 2015

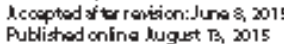

\section{Critical Analyses of the Introduction of Liquid-Based Cytology in a Public Health Service of the State of São Paulo, Brazil}

Adhemar Longatto-Filho ${ }^{\mathrm{a}}$ e tr-j JoséEduardo Levid,e Toni Ricardo Martins ${ }^{d}$

Diane Cohen ${ }^{\dagger}$ Lise Cury ${ }^{\dagger}$ Luisa Lina Villaceg José Eluf-Neto ${ }^{\text {b. f.g }}$ 


\title{
3. HPV genotype distribution in Brazilian women with and without cervical lesions: correlation to cytological data
}

\section{HPV genotype distribution in Brazilian women with and without cervical lesions: correlation to cytological data}

Toni Ricardo Martins ${ }^{1,22^{*}}$, Cristina Mendes de Oliveira', Luciana Reis Rosa', Cristiane de Campos Centrone', Célia Luiza Regina Rodrigues', Luisa Lina Villa ${ }^{3 / 4}$ and José Eduardo Levi ${ }^{1 / 4}$

\begin{abstract}
Background: Human Papillomavirus (HPV) genotype distribution varies according to the method of assessment and population groups. This study analyzed type-specific HPV infections among women ranging from 14-95 years old, displaying normal and abnormal cytology, from São Paulo and Barretos cities, Brazil.

Methods: Women found positive for High Risk-HPVs DNA by either the Hybrid Capture 2 (HC2) or Cobas HPV Test $(n=431)$ plus a random sample of 223 negative by both assays and 11 samples with indeterminate results, totalizing 665 samples, were submitted to HPV detection by the PapilloCheck test. Cytological distribution induded 499 women with a cytological result of Negative for Intraepithelial Lesion or Malignancy and 166 with some abnormality as follows: 54 Atypical Squamous Cells of Undetermined Significance; 66 Low-Grade Squamous Intraepithelial Lesion; 43 High-Grade Squamous Intraepithelial Lesion and $3(0.5 \%)$ Invasive Cervical Cancer.

Results: From the 323 samples (48.6 \%) that had detectable HPV-DNA by the Papillocheck assay, 31 were HPV negative by the cobas HPV and HC2 assays. Out of these 31 samples, 14 were associated with HR-HPVs types while the remaining 17 harbored exclusively low-risk HPVs. In contrast, 49 samples positive by cobas HPV and HC 2 methods tested negative by the PapilloCheck assay $(19.8 \%)$. Overall, the most frequent HR-HPV type was HPV 16 (23.2\%), followed by 56 (21.0\%), $52(8.7 \%)$ and 31 (7.7\%) and the most frequent LR-HPV type was HPV 42 (12.1\%) followed by 6 (6.2\%). Among the HR-HPV types, HPV 56 and 16 were the most frequent types in NILM, found in 19 1 and $17.7 \%$ of the patients respectively while in HSIL and ICC cases, HPV 16 was the predominant type, detected in 37.2 and $66.7 \%$ of these samples.

Conclusions: In the population studied, HPV 16 and 56 were the most frequently detected HR-HPV types. HPV 56 was found mainly in LSIL and NILM suggesting a low oncogenic potential. HPV 16 continues to be the most prevalent type in high-grade lesions whereas HPV 18 was found in a low frequency both in NILM and abnormal smears. Surveillance of HPV infections by molecular methods is an important tool for the development and improvement of prevention strategies.
\end{abstract}

Keywords: Cervical Cancer, Cytology, HPV, HPV types, PapilloCheck 
4. Influence of prior knowledge of HPV status on the performance of cytology screening performance.

Toni Ricardo Martins, Adhemar Longatto-Filho, Diane Dede Cohen, Juliana Yukari Kodaira Viscondi, Luiz Mario Santos_Fuza, Lise Cury, Luisa Lina Villa, José Eduardo Levi, José Eluf Neto.

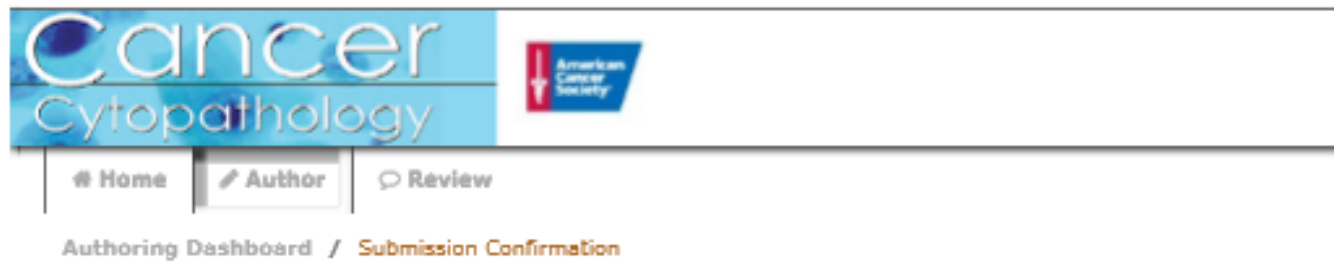

\section{Submission Confirmation}

Thank you for your submission

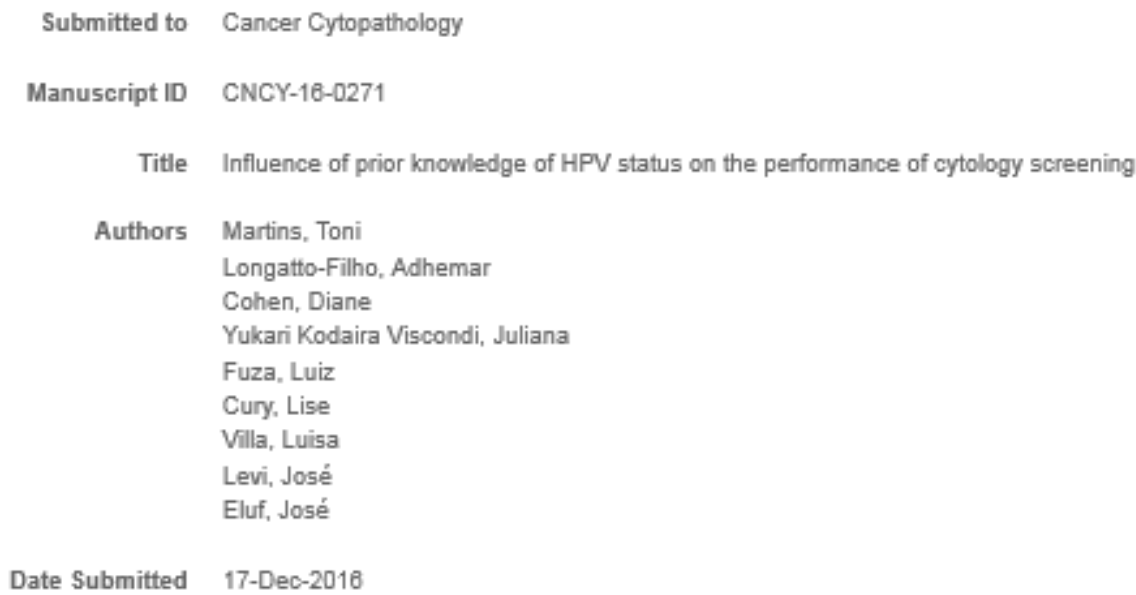




\section{Exploring new worlds in research HPV 2@15}

$30^{\text {TH }}$ INTERNATIONAL PAPILLOMAVIRUS CONFERENCE \&. CLINICAL AND PUBLIC HEALTH WORKSHOPS

September 17-21, 2015 Lisbon, Portugal

Abstract \#: HPV15-0543

EVALUATION OF THE BD ONCLARITYTM HPV ASSAY IN PRIMARY SCREENING FOR CERVICAL CANCER: PRELIMINARY RESULTS

Toni Ricardo Martins, Diane Dede Cohen, Luiz Mario Santos_Fuza, Lise Cury, Adhemar Longatto-Filho, Luisa Lina Villa, José Eduardo Levi, José Eluf Neto

Abstract \#: HPV15-0554

LARGE SCALE DISTRIBUTION OF HPV GENOTYPES IN BRAZILIAN WOMEN WITH AND WITHOUT CERVICAL LESIONS: CORRELATION WITH CYTOLOGICAL DATA

Toni Ricardo Martins, Luciana Reis Rosa, Cristiane de Campos Centrone, Célia Luiza da Silva, Cristina Mendes de Oliveira, José Eduardo Levi. 


\section{EUROGIN 2016}

Salzburg, Austria

June $15-18,2016$

\section{PARALLEL TESTING FOR HIGH-RISK HPV AND LIQUID BASED CYTOLOGY IN PRIMARY SCREENING FOR CERVICAL CANCER}

José Eduardo Levi, Toni Ricardo Martins, Adhemar Longatto-Filho, Diane Dede Cohen, Luiz Mario Santos Fuza, Lise Cury, Luisa Lina Villa, José Eluf Neto.

\section{FOCALPOINT COMPUTER-ASSISTED PAP TEST SCREENING: VALIDATION TECHNOLOGY STUDY FOR IMPLEMENTATION IN A PUBLIC HEALTH SERVICE.}

Toni Ricardo Martins, Adhemar Longatto-Filho, José Eduardo Levi, Diane Dede Cohen, Luiz Mario Fuza, Lise Cury, Luisa Lina Villa, José Eluf Neto.

\section{IMPACT OF HPV 16, 18 AND OTHER HR-HPV TYPES ON INVASIVE CERVICAL CANCER SURVIVAL IN BRAZIL}

Maria Luiza Nogueira Dias Genta, Jesus Paula Carvalho, Rossana Mendonza Lopez,

Toni Ricardo Martins, José Eduardo Levi.

Trabalhos apresentados em congresso

GOLFETTO, L., ALVES, E. V., MARTINS, T. R., SINCERO, T. M., OLIVEIRA, J. G., BAZZO, M. L. Detecção simultânea de HPV e Chlamydia Trachomatis em amostras de cérvice uterina em amostras de 325 mulheres sexualmente ativas. $X$ Congresso da Sociedade Brasileira de DST e VI Congresso Brasileiro de AIDS, 2015.

GOlfETtO, L., MARTINS, T. R., AlVES, E. V., CARMO, A. P., SinCERO, T. M., BAZZO, M. L. Detecção de HPV em amostras da cérvice uterina. IX Congresso da Sociedade Brasileira de DST e V Congresso Brasileiro de AIDS, 2013. 


\section{$3^{\circ}$ CONGRESSO PAN AMAZÔNICO DE ONCOLOGIA}

Detecção de HPV e Tipagem simultânea: novas ferramentas e algoritmos

(Palestrante).

Manaus, 11 a 14 de novembro de 2015.

HPV de "A a Z" (Palestrante). Jornada da Saúde: cuidados com a saúde da mulher. Universidade Paulista, maio de 2015.

HPV e o câncer de colo de útero (Palestrante). Curso Teórico-Prático para Profissionais de Saúde em Ações de Rastreamento do Câncer de Colo do Útero. Fundação Oncocentro de São Paulo, abril de 2015.

HPV de "A a Z" (Palestrante). IV SIPAT (Semana Interna de Prevenção de Acidentes). Fundação Oncocentro de São Paulo, dezembro de 2014.

HPV e o câncer de colo de útero (Palestrante). Curso Teórico-Prático para Profissionais de Saúde em Ações de Rastreamento do Câncer de Colo do Útero. Fundação Oncocentro de São Paulo, novembro de 2014.

HPV e o câncer de colo de útero (Palestrante). Curso Teórico-Prático para Profissionais de Saúde em Ações de Rastreamento do Câncer de Colo do Útero. Fundação Oncocentro de São Paulo, outubro de 2014.

Diagnóstico dos HPVs: da citologia oncótica aos testes moleculares (Palestrante). Semana de Estudos em Análises Clínicas (SEAC), Universidade Federal de Santa Catarina (UFSC), setembro de 2013. 
9. Referências Bibliográficas 
Almonte M, Sasieni P, Cuzick J. Incorporating human papillomavirus testing into cytological screening in the era of prophylactic vaccines. Best Pract Res Clin Obstet Gynaecol. 2011;(5):617-29.

Altiok, S. Molecular markers in cervical cytology. Clin Lab Med. 2003;(3):709-28.

Arbyn M, Paraskevaidis E, Martin-Hirsch P, Prendiville W, Dillner J. Clinical utility of HPV-DNA detection: Triage of minor cervical lesions, follow-up of women treated for high-grade CIN: An update of pooled evidence. Gynecol Oncol. 2005;99(3 Suppl 1):S7-11.

Arbyn M, Bergeron C, Klinkhamer P, Martin-Hirsch P, Siebers AG, Bulten J. Liquid compared with conventional cervical cytology: a systematic review and meta-analysis.

Obstet Gynecol. 2008;(1):167-77.

Arbyn M, Ronco G, Meijer CJ, Naucler P. Trials comparing cytology with human papillomavirus screening. Lancet Oncol. 2009;(10):935-6.

Ault KA. Cervical cancer prevention: better tests, better tools, and more equitable outcomes. J Natl Cancer Inst. 2011;103(18):1352-3.

Ayres, A R G.; Silva, G.A. Prevalência de infecção do colo do útero pelo HPV no Brasil: revisão sistemática Rev. Saúde Pública. 2010;44(5):963-74.

Baldez da Silva MF, Chagas BS, Guimaraes V, Katz LM, Felix PM, Miranda PM, et al. HPV31 and HPV33 incidence in cervical samples from women in Recife, Brazil. Genet Mol Res. 2009;8(4):1437-43.

Benoy IH, Vanden Broeck D, Ruymbeke MJ, Sahebali S, Arbyn M, Bogers JJ, et al. Prior knowledge of HPV status improves detection of CIN2+ by cytology screening. Am J Obstet Gynecol. 2011;205:569.e1-567.

Bergeron C, Ronco G, Reuschenbach M, Wentzensen N, Arbyn M, Stoler M. et al. The clinical impact of using p16INK4a immunochemistry in cervical histopathology and cytology: An update of recent developments. Int J Cancer. 2015a;136(12):2741-51.

Bergeron C, Giorgi-Rossi P, Cas F, Schiboni ML, Ghiringhello B, Dalla Palma P, et al. Informed cytology for triaging HPV-positive women: substudy nested in the NTCC randomized controlled trial. J Natl Cancer Inst. 2015b;107:dju423.

Bergeron, C; von Knebel Doeberitz, M. The Role of Cytology in the 21st Century: The Integration of Cells and Molecules. Acta Cytol. 2016;60(6):540-542.

Berkhof J, Coupé VM, Bogaards JA, van Kemenade FJ, Helmerhorst TJ, Snijders PJ, et al. The Health and Economic Effects of HPV DNA Screening in The Netherlands. Int J Cancer. 2010;127(9):2147-58. 
Bernard HU, Chan SY, Manos MM, Ong CK, Villa LL, Delius H, et al. Identification and assessment of know and novel human papillomaviruses by polymerase chain reaction amplification, restriction fragment length polymorphisms, nucleotide sequence, and phylogenetic algorithms. J Infect Dis.1994;170:1077-1085.

Bernard HU. The clinical importance of the nomenclature, evolution and taxonomy of human papillomaviruses. J Clin Virol. 2005; 32:1-6.

Bosch FX, Lorincz A, Munoz N, Meijer CJ, Shah KV. The causal relation between human papillomavirus and cervical cancer. J Clin Pathol. 2002;55(4):244-65.

Bosch FX, de SS. Chapter 1: Human papillomavirus and cervical cancer-burden and assessment of causality. J Natl Cancer Inst Monogr. 2003;(31):3-13.

Bottari F, Sideri M, Gulmini C, Igidbashian S, Tricca A, Casadio C, et al. Comparison of Onclarity human papillomavirus (HPV) assay with Hybrid Capture II HPV DNA assay for detection of cervical intraepithelial neoplasia grade 2 and 3 lesions. J Clin Microbiol. 2015;(7):2109-14.

Bruni L, Diaz M, Castellsagué X, Ferrer E, Bosch FX, de Sanjosé S. Cervical human papillomavirus prevalence in 5 continents: meta-analysis of 1 million women with normal cytological findings. J Infect Dis. 2010;202 (12):1789-99.

Bruno A, Serravalle K, Travassos AG, Lima BGC. Distribuição dos Genótipos de papillomavírus humano em mulheres do estado da Bahia, Brasil. Rev Bras Ginecol Obstet. 2014;36(9):416-22.

Bulkmans NWJ, Rozendaal L, Voorhorst FJ, Boeke A.J.P., Snijders P.J.F., Meijer C.J.L.M. POBASCAM, a populationbased randomised controlled trial for implementation of high-risk HPV testing in cervical screening. Int J Cancer. 2004;110(1):94-101.

Carozzi F, Gillio-Tos A, Confortini M, Del Mistro A, Sani C, De Marco L, et al. Risk of high-grade cervical intraepithelial neoplasia during follow-up in HPV- positive women according to baseline p16-INK4A results: a prospective analysis of a nested substudy of the NTCC randomised controlled trial. Lancet Oncol. 2013;14(2):168-76.

Castellsagué X. Natural history and epidemiology of HPV infection and cervical câncer. Gynecol Oncol. 2008;110(3 Suppl 2):S4-7.

Castilho JL, Levi JE, Luz PM, Cambou MC, Vanni T, de Andrade A, et al. A crosssectional study of high-risk human papillomavirus clustering and cervical outcomes in HIV-infected women in Rio de Janeiro, Brazil. BMC Cancer. 2015;15:478. 
Castle PE, Schiffman M, Herrero R, Hildesheim A, Rodriguez AC, Bratti MC, et al. A prospective study of age trends in cervical human papillomavirus acquisition and persistence in Guanacaste, Costa Rica. J Infect Dis. 2005;191(11):1808-16.

Castle PE, Cox JT, Jeronimo J, Solomon D, Wheeler CM, et al. An Analysis of HighRisk Human Papillomavirus DNA-Negative Cervical Precancers in the ASCUS-LSIL Triage Study (ALTS). Obstet Gynecol. 2008;111(4):847-56.

Castle PE, Fetterman B, Poitras N, Lorey T, Shaber R, Kinney W. Five year experience of human papillomavirus DNA and Papanicolaou test contesting. Obstet Gynecol 2009a; 113(3): 595-600.

Castle PE, Schiffman M, Wheeler CM, Solomon D. Evidence for frequent regression of cervical intraepithelial neoplasia-grade 2. Obstet Gynecol. 2009b ;113(1):18-25.

Castle PE, Stoler MH, Wright TC Jr, Sharma A, Wright TL, Behrens CM. Performance of carcinogenic human papillomavirus (HPV) testing and HPV16 or HPV18 genotyping for cervical cancer screening of women aged 25 years and older: a subanalysis of the ATHENA study. Lancet Oncol. 2011a;12(9):880-90.

Castle PE, Gutierrez EC, Leitch SV, Maus CE, McMillian RA, Nussbaumer WA, et al. Evaluation of a New DNA Test for Detection of Carcinogenic Human Papillomavirus. J Clin Microbiol. 2011b;49(8):3029-32.

Castle, PE. Gynaecological cancer: New standard of care HPV testing for cervical cancer screening . Nat Rev Clin Oncol. 2015;12(4):194-6.

Cavalcanti, S.M.B.; Carestiato, F.N. Infecções Causadas Pelos Papilomavírus Humanos: Atualização Sobre Aspectos Virológicos, Epidemiológicos e Diagnóstico Review. J. Bras. Doenças Sex. Transm. 2006;18(1): 73-79.

Chatterjeev, A. The next generation of HPV vaccines: nonavalent vaccine V503 on the horizon. Expert Rev Vaccines. 2014;13(11):1279-90.

Chen HC, Schiffman M, Lin CY, Pan MH, You SL, Chuang LC, et al. Persistence of Type-Specific Human Papillomavirus Infection and Increased Long-term Risk of Cervical Cancer. J Natl Cancer Inst. 2011;103(18):1387-96.

Cheung JLK, Cheung T-H, Yu MY, Chan PK. Virological characteristics of cervical cancers carrying pure episomal form of HPV16 genome. Gynecol Oncol. 2013;131(2):374-9.

Ciuffo G. Innesto positivo con filtrato di verruca volgare. G. Ital. Mal. Ven. Pelle.1907; 48:12-17.

Clarck GH. The charming of warts. J Invest Dermatol.1965;45:15-21. 
Clavel C, Masure M, Bory JP, Putaud I, Mangeonjean C, Lorenzato M, et al. Human papillomavirus testing in primary screening for the detection of high-grade cervical lesions: a study of 7932 women. Br J Cancer. 2001;84(12):1616-23.

Cox JT, Castle PE, Behrens CM, Sharma A, Wright TC Jr, Cuzick J; et al. Comparison of cervical cancer screening strategies incorporating different combinations of cytology, HPV testing, and genotyping for HPV 16/18: results from the ATHENA HPV study. Am J Obstet Gynecol. 2013;208(3):184.e1-184.e11.

Cuzick J, Mayrand MH, Ronco G, Snijders P, Wardle J. Chapter 10: New dimensions in cervical cancer screening. Vaccine. 2006;24 Suppl 3:S3/90-7.

Cuzick J, Szarewski A, MesherD,CadmanL,AustinJ,Perryman,Ketal. Long-term followup of cervical abnormalities among women screened by HPV testing and cytology. Results from the Hammer smith study. Int J Cancer. 2008a;122:2294-300.

Cuzick J, Arbyn M, Sankaranarayanan R, Tsu V, Ronco G, Mayrand MH. et al., Overview of human papillomavirus-based and other novel options for cervical cancer screening in developed and developing countries. Vaccine. 2008b;26 Suppl 10:K29-41.

Cuzick, J. Need for expanded HPV genotyping for cervical screening. Papillomavirus Research 2 (2016), 112-115.

Dalstein V, Merlin S, Bali C, Saunier M, Dachez R, Ronsin C. Analytical evaluation of the PapilloCheck test, a new commercial DNA chip for detection and genotyping of human papillomavirus. J Virol Methods. 2009;156:77-83.

de Cremoux P, Coste J, Sastre-Garau X, Thioux M, Bouillac C, et al. Efficiency of the Hybrid Capture 2 HPV DNA Test in Cervical Cancer Screening. A Study by the French Society of Clinical Cytology. Am J Clin Pathol. 2003 Oct;120(4):492-9.

de Oliveira CM, Fregnani JH, Carvalho JP, Longatto-Filho A, Levi JE. Human papillomavirus genotypes distribution in 175 invasive cervical cancer cases from Brazil. BMC Cancer. 2013;13:357.

de Oña M, Alvarez-Argüelles ME, Torrents M, Villa L, Rodriguez-Feijoo A, Palacio A. et al. Evolution, and Features of Infection with Human Papillomavirus: A 15-Year Longitudinal Study of Routine Screening of a Women Population in the North of Spain. J Med Virol. 2010;82(4):597-604.

de Roda Husman AM, Walboomers JM, van den Brule AJ, Meijer CJ, Snijders PJ. The use of general primers GP5 and GP6 elongated at their 3'ends with adjacent highly conserved sequences improves human papillomavirus detection by PCR. J Gen Virol. 1995;76 ( Pt 4):1057-62.

de Sanjosé S, Diaz M, Castellsagué X, Clifford G, Bruni L, Muñoz N. et al. Worldwide prevalence and genotype distribution of cervical human papillomavirus DNA in women with normal cytology: a meta-analysis. Lancet Infect Dis. 2007;7(7):453-9. 
de Sanjose S, Quint WG, Alemany L, Geraets DT, Klaustermeier JE, Lloveras B. et al. Retrospective International Survey and HPV Time Trends Study Group. Human Papillomavirus genotype attribution in invasive cervical cancer: a retrospective crosssectional worldwide study. Lancet Oncol. 2010;11(11):1048-56.

de Villiers EM, Fauquet C, Broker TR, Bernard HU, zur Hausen H. Classification of papillomaviruses. Virology. $2004 ; 324(1): 17-27$.

Dijkstra MG, van Niekerk D, Rijkaart DC, van Kemenade FJ, Heideman DA, Snijders PJ, et al. Primary hrHPV DNA testing in cervical cancer screening: how to manage screen-positive women? A POBASCAM trial substudy. Cancer Epidemiol Biomarkers Prev. 2014;23(1):55-63.

Dillner J, Rebolj M, Birembaut P, Petry KU, Szarewski A, Munk C. Long term predictive values of cytology and human papillomavirus testing in cervical cancer screening: joint European cohort study. BMJ. 2008;337:a1754.

Doorbar J1, Egawa N, Griffin H, Kranjec C, Murakami I. Human papillomavirus molecular biology and disease association. Rev Med Virol. 2015;25 Suppl 1:2-23.

Doorbar, J. The papillomavirus life cycle. J Clin Virol. 2005; 32:7-15.

Ejegod, D. M. Clinical Validation of the BD Onclarity ${ }^{\mathrm{TM}}$ HPV Assay Using a NonInferiority Test. J Med Microb Diagn. 2013; Suppl3.

Farthing A, Masterson P, Mason WP, Vousden KH. Human papillomavirus detection by hybrid capture and its possible clinical use. J Clin Pathol. 1994;47(7):649-52.

Fehrmann F, Laimins L. Human papillomaviruses: targeting differentiating epithelial cells for malignant transformation. Oncogene. 2003; 22:5201-7.

Ferenczy A, Franco E. Cervical-cancer screening beyond the year 2000. Lancet Oncol. 2001;2(1):27-32.

Ferlay J, Shin HR, Bray F, Forman D, Mathers C, Parkin DM. GLOBOCAN 2008, Cancer Incidence and Mortality Worldwide: IARC CancerBase $\mathrm{n}^{\circ} .10$ [Internet]. Lyon, France: International Agency for Research on Cancer; 2010. Available from: http://globocan.iarc.fr.

Fernandes JV, Meissner Rde V, de Carvalho MG, Fernandes TA, de Azevedo PR, et al. Prevalence of HPV infection by cervical cytologic status in Brazil. Int J Gynaecol Obstet. 2009;105(1):21-4.

Fernandes JV, Meissner RV, Carvvalho MGF, Fernandes TAAM, Azevedo PRM, Sobrinho SJ, et al. Prevalence of human papillomavirus in archival samples obtained from patients with cervical pre-malignant and malignant lesions from Northeast Brazil. BMC Research Notes.2010;3:96. 
Ferreccio C, Barriga MI, Lagos M, Ibáñez C, Poggi H, González F, et al. Screening trial of human papillomavirus for early detection of cervical cancer in Santiago, Chile. Int J Cancer. 2013;132(4):916-23.

Ferreira, A. W; Moraes, S.L. Diagnóstico Laboratorial das Principais Doenças Infecciosas e Autoimunes, Terceira Edição. Seção 2, Capítulo 8 - Infecção por HPV, Rio de Janeiro: Guanabara Koogan;2013:113-119

Flores YN, Bishai DM, Lorincz A, Shah KV, Lazcano-Ponce E, Hernández M, et al. HPV Testing for Cervical Cancer Screening Appears More Cost-Effective than Papanicolaou cytology in Mexico. Cancer Causes Control. 2011 Feb;22(2):261-72

Franco, EL. A new generation of studies of human papillomavirus DNA testing in cervical cancer screening. J Natl Cancer Inst. 2009;101(23):1600-1

Frazer, I. H. Prevention of cervical câncer through papillomavirus vaccination. Nat Rev Immunol. 2004;4(1):46-54.

Fuessel Haws AL, He Q, Rady PL, Zhang L, Grady J, Hughes TK. et al. Nested PCR with the PGMY09/11 and GP5+/6+ primer sets improves detection of HPV DNA in cervical samples. J Virol Methods. 2004;122(1):87-93.

Gage JC, Hanson VW, Abbey K, Dippery S, Gardner S, Kubota J, et al. Number of cervical biopsies and sensitivity of colposcopy. Obstet Gynecol 2006;108:264-272

Gompel, C. Koss, L. G. Citologia ginecológica e suas bases anatômicas. 1 ed. São Paulo: Manole, 1997.

Gravitt PE, Peyton CL, Alessi TQ, Wheeler CM, Coutlée F, Hildesheim A, et al. Improved Amplification of Genital Human Papillomaviruses. J Clin Microbiol. 2000;38:357-61.

Guo M, Hu L, Baliga M, He Z, Hughson MD. The predictive value of p16(INK4a) and hybrid capture 2 human papillomavirus testing for high-grade cervical intraepithelial neoplasia. Am J Clin Pathol. 2004;122(6):894-901.

Herbert A. Primary HPV testing: a proposal for co-testing in initial rounds of screening to optimise sensitivity of cervical cancer screening. Cytopathology. 2016 [Epub ahead of print].

Herrington, C. S. Do HPV-negative cervical carcinomas exist?-Revisited. Journal of Pathology. Editorial,1999;189:1-3.

Hubbard, RA. Human papillomavirus testing methods. Arch Pathol Lab Med. 2003 ;127(8):940-5. 
Huh WK, Ault KA, Chelmow D, Davey DD, Goulart RA, Garcia FA, et al. Use of primary high-risk human papillomavirus testing for cervical cancer screening: interim clinical guidance. Gynecol Oncol. 2015 ;136(2):178-82.

Ikenberg H, Bergeron C, Schmidt D, Griesser H, Alameda F, Angeloni C, et al. Screening for cervical cancer precursors with p16/Ki-67 dual-stained cytology: results of the PALMS study. J Natl Cancer Inst. 2013;105(20):1550-7.

Instituto Nacional do Câncer (Inca). $2^{\circ}$ Informativo detecção precoce 2012. Monitoramento das ações de controle dos cânceres do colo do útero e de mama. Boletim $\mathrm{n}^{\circ} 2$ - abril a julho / 2012. Coordenação Geral de Prevenção e Vigilância. Disponível em http:www.inca.gov.br.

Instituto Nacional do Câncer (Inca). Estimativa 2016. Disponível em: http://www.inca.gov.br. Acesso em 20 de julho de 2016.

International Agency for Research on Cancer (IARC). Chapter 2: An introduction to cervical intraepithelial neoplasia (CIN). Disponível em: http://screening.iarc.fr/colpochap.php?lang=4\&chap=2. Acesso em 20 de setembro de 2014.

Jeantet D, Schwarzmann F, Tromp J, Melchers WJ, van der Wurff AA, Oosterlaken T.et al. NucliSENS ${ }^{\circledR}$ EasyQ ${ }^{\circledR}$ HPV v1 test Testing for oncogenic activity of human papillomaviruses. J Clin Virol. 2009;45 Suppl 1:S29-37.

Joste N, Gober-Wilcox J. The modern cytology laboratory: moving beyond the Pap test. Obstet Gynecol Clin North Am. 2013;40(2):199-210.

Khan MJ, Castle PE, Lorincz AT, Wacholder S, Sherman M, Scott DR, et al. The elevated 10-year risk of cervical precancer and cancer in women with human papillomavirus (HPV) type 16 or 18 and the possible utility of type-specific HPV testing in clinical practice. J Natl Cancer Inst. 2005;97(14):1072-9.

Kisser A, Zechmeister-Koss I. A systematic review of p16/Ki-67 immuno-testing for triage of low grade cervical cytology. BJOG. 2015;122(1):64-70.

Kitchener HC, Almonte M, Wheeler P, Desai M, Gilham C, Bailey A. et al. HPV testing in routine cervical screening: cross sectional data from the ARTISTIC trial. Br J Cancer. 2006;95(1):56-61.

Kjaer SK, van den Brule AJ, Paull G, Svare EI, Sherman ME, Thomsen BL. et al. Type specific persistence of high risk human papillomavirus (HPV) as indicator of high grade cervical squamous intraepithelial lesions in young women: population based prospective follow up study. BMJ. 2002;325(7364):572.

Koss, L.G. The Papanicolaou test for cervical cancer detection. A triumph and a tragedy. JAMA. 1989;261(5):737-43. 
Lazcano-Ponce E, Lőrincz AT, Torres L, Salmerón J, Cruz A, Rojas R. et al. Specimen self-collection and HPV DNA screening in a pilot study of 100,242 women. Int J Cancer. 2014;135(1):109-16.

Leinonen M1, Nieminen P, Kotaniemi-Talonen L, Malila N, Tarkkanen J, Laurila P, et al. Age-specific evaluation of primary human papillomavirus screening vs conventional cytology in a randomized setting. J Natl Cancer Inst. 2009 ;101(23):1612-23.

Levi JE, Longatto-filho A, Eluf-neto J, Rodrigues CL, Oliveira CM, Carloni AC, et al. Evaluation of HPV molecular tests in primary screening for cervical cancer in Brazil. Open J Obstet Gynecol. 2014;4:470-8.

Li N, Franceschi S, Howell-Jones R, Snijders PJF, Clifford GM. Human Papillomavirus type distribution in 30,848 invasive cervical cancers worldwide: variation by geographical region, histological type and year of publication. Int J Cancer.2011; 128:927-35.

Lie AK, Kristensen G. Human Papillomavirus E6/E7 mRNA Testing as a Predictive Marker for Cervical Carcinoma. Expert Rev Mol Diagn. 2008 ;(4):405-15.

Longatto-Filho A, Schmitt FC. Gynecological cytology: too old to be a pop star but too young to die. Diagn Cytopathol. 2007;35(10):672-3.

Longatto-Filho A, Schmitt FC. Cytology education in the 21st century: living in the past or crossing the Rubicon? Acta Cytol. 2010 ;54(4):654-6.

Longatto-Filho A, Levi JE, Martins TR, Cohen D, Cury L, Villa LL, et al . Critical Analyses of the Introduction of Liquid-Based Cytology in a Public Health Service of the State of São Paulo, Brazil. Acta Cytol. 2015;59(3):273-7.

Lorenzi AT, Syrjänen KJ, Longatto-Filho A. Human papillomavirus (HPV) screening and cervical cancer burden. A Brazilian perspective. Virol J. 2015 25;12:112.

Manual de Gestão de Qualidade para Laboratório de Citopatologia (2016). http://www1.inca.gov.br/inca/Arquivos/livro_completo_manual_citopatologia.pdf.

Acesso em 20 de novembro de 2016.

Matsumoto K, Oki A, Furuta R, Maeda H, Yasugi T, Takatsuka N, Predicting the progression of cervical precursor lesions by human papillomavirus genot yping: a prospective cohort study. Int J Cancer. 2011;128(12):2898-910.

Mayrand MH, Duarte-Franco E, Rodrigues I, Walter SD, Hanley J, Ferenczy A, et al. Human papillomavirus DNA versus Papanicolaou screening tests for cervical cancer. $\mathbf{N}$ Engl J Med. 2007;357(16):1579-88. 
McGoogan E, Colgan TJ, Ramzy I, Cochand-Priollet B, Davey DD, Grohs HK, et al. Cell preparation methods and criteria for sample adequacy. International Academy of Cytology Task Force summary. Diagnostic Cytology Towards the 21st Century: An International Expert Conference and Tutorial. Acta Cytol. 1998;42(1):25-32.

Mclaughlin-Drubin, M.E.; Park, D; Munger, K. Tumor suppressor p16INK4A is necessary for survival of cervical carcinoma cell lines. Proc Natl Acad Sci U S A. 2013 ;110(40):16175-80.

Molijn A, Kleter B, Quint W, van Doorn LJ. Molecular diagnosis of human papillomavirus (HPV) infections. J Clin Virol. 2005 ;32 Suppl 1:S43-51.

Monsonego J, Hudgens MG, Zerat L, Zerat JC, Syrjänen K, Halfon P. et al. Evaluation of oncogenic human papillomavirus RNA and DNA tests with liquid based cytology in primary cervical cancer screening (the FASE study). Int J Cancer. 2011;129(3):691701.

Monsonego J, Hudgens MG, Zerat L, Zerat JC, Syrjänen K, Smith JS. Risk assessment and clinical impact of liquid-based cytology, oncogenic human papillomavirus (HPV) DNA and mRNA testing in primary cervical cancer screening (The FASE Study). Gynecol Oncol. 2012;125(1):175-80.

Monsonego J, Cox JT, Behrens C, Sandri M, Franco EL, Yap PS, et al. Prevalence of high-risk human papilloma virus genotypes and associated risk of cervical precancerous lesions in a large U.S. screening population: data from the ATHENA trial. Gynecol Oncol 2015;137:47-54.

Moody CA, Laimins LA. Human papillomavirus oncoproteins: pathways to transformation. Nat Rev Cancer. 2010;10(8):550-60.

Moscicki, AB. Impact of HPV infection in adolescent populations - J Adolesc Health. 2005;37(6 Suppl):S3-9.

Moyer VA; U.S. Preventive Services Task Force. Screening for Cervical Cancer: U.S. Preventive Services Task Force Recommendation Statement. Ann Intern Med. 2012 ;156(12):880-91

MS-Inca (Ministério da Saúde / Instituto Nacional do Câncer). Diretrizes Brasileiras para o rastreamento Do Câncer Do Colo Do Útero. Rio de Janeiro, 2011. Disponível em:http://www1.inca.gov.br/inca/Arquivos/Diretrizes_rastreamento_cancer_colo_utero. pdf. Acesso em 01 de setembro de 2015.

Nam K, Chung S, Kwak J, Cha S, Kim J, Jeon S, et al. Random biopsy after colposcopy-directed biopsy improves the diagnosis of cervical intraepithelial neoplasia grade 2 or worse. J Low Genit Tract Dis. 2010;14:346-351. 
Nanda K, McCrory DC, Myers ER, Bastian LA, Hasselblad V, Hickey JD. et al. Accuracy of the Papanicolaou test in screening for and follow-up of cervical cytologic abnormalities: a systematic review. Ann Intern Med. 2000;132(10):810-9.

Naucler P, Ryd W, Törnberg S, Strand A, Wadell G, Elfgren K, et al. Efficacy of HPV DNA Testing With Cytology Triage and/or Repeat HPV DNA Testing in Primary Cervical Cancer Screening. J Natl Cancer Inst. 2009;101(2):88-99.

Nayar, R; Wilbur, D.C. The Bethesda System for Reporting Cervical Citology Definitions, Criteria, and Explanatory Notes. Springer International Publishing Switzerland, 2015.

Noronha V, Mello W, Villa L, Brito A, Macedo R, Bisi F, et al. Papilomavírus humano associado a lesões de cérvice uterina. Rev. Soc. Bras. Med. Trop. 1999;32:235-40.

Otero-Motta AP, Ordonez JL, Gonzalez-Celador R, Rivas B, Macias Mdel C, Bullon A, et al. Prevalence of human papillomavirus genotypes in cytologic abnormalities from unvaccinated women living in north-western Spain. APMIS. 2011;119(3):204-15

Portal Brasil Ministério da Saúde 2015. Acesso em 22/11/2016. http://portalsaude.saude.gov.br/index.php/cidadao/principal/agencia-saude/19654ministerio-da-saude-habilita-laboratorios-de-exames-citopatologicos-no-rio-de-janeiro

Portal Brasil Ministério da Saúde 2016a. Acesso em 22/11/2016. http://www.brasil.gov.br/saude/2016/04/campanha-incentiva-meninas-a-procurarvacinacao-contra-hpvPortal saúde

Portal Brasil Ministério da Saúde 2016b. Acesso em 22/11/2016. http://www.brasil.gov.br/saude/2016/10/meninos-poderao-ser-vacinados-contra-hpv-apartir-de-2017

Porras C, Wentzensen N, Rodriguez AC, Morales J, Burk RD, Alfaro M, et al. Switch from cytology-based to human papillomavirus test-based cervical screening: implications for colposcopy. Int J Cancer 2012;130:1879-1887

Rabelo-Santos SH, Zeferino L, Villa LL, Sobrinho JP, Amaral RG, Magalhães AV. Human papillomavirus prevalence among women with cervical intraepithelial neoplasia III and invasive cervical cancer from Goiânia, Brazil. Mem Inst Oswaldo Cruz. 2003 Mar;98(2):181-4

Rama C, Roteli-Martins C, Derchain S, Longatto-Filho A, Gontijo R, Sarian L. et al. Rastreamento anterior para câncer de colo uterino em mulheres com alterações citológicas ou histológicas Rev Saude Publica. 2008;42(3):411-9.

Ratnam S, Coutlee F, Fontaine D, Bentley J, Escott N, Ghatage P. et al. Clinical Performance of the PreTect HPV-Proofer E6/E7 Mrna Assay in Comparison with That of the Hybrid Capture 2 Test for Identification of Women at Risk of Cervical Cancer. J Clin Microbiol. 2010;48(8):2779-85. 
Richardson LA, El-Zein M, Ramanakumar AV, Ratnam S, Sangwa-Lugoma G, Longatto-Filho A, et al. HPV DNA Testing With Cytology Triage in Cervical Cancer Screening: Influence of Revealing HPV Infection Status. Cancer Cytopathol. 2015;123(12):745-54.

Richart RM. The natural history of cervical intraepithelial neoplasia. Clin Obstet Gynecol. 1967;10(4):748 -784.

Rijkaart DC, Berkhof J, Rozendaal L, van Kemenade FJ, Bulkmans NW, Heideman DA, et al. Human Papillomavirus testing for the detection of high-grade cervical rodaintraepithelial neoplasia and cancer: final results of the POBASCAM randomised controlled trial. Lancet Oncol. 2012;13(1):78-88.

Ronco G, Segnan N, Giorgi-Rossi P, Zappa M, Casadei GP, Carozzi F et al. Human papillomavirus testing and liquid based cytology: results at recruitment from the new technologies for cervical cancer randomized controlled trial. J Natl Cancer Inst. 2006 ;98(11):765-74.

Ronco G, Cuzick J, Pierotti P, Cariaggi MP, Dalla Palma P, Naldoni C. et al. Accuracy of liquid based versus conventional cytology: overall results of new technologies for cervical cancer screening: randomised controlled trial. BMJ. 2007;335(7609):28.

Ronco G, Dillner J, Elfström KM, Tunesi S, Snijders PJ, Arbyn M. et al. Efficacy of HPV-based screening for prevention of invasive cervical cancer: follow-up of four European randomized controlled trials. Lancet. 2014;383(9916):524-32.

Rosenblatt C, Wroclawski ER, Lucon, AM, Pereyra EAG. HPV na prática clínica. São Paulo. Atheneu:2005.

Sankaranarayanan R, Nene BM, Shastri SS, Jayant K, Muwonge R, Budukh AM, et al. HPV Screening for Cervical Cancer in Rural India. N Engl J Med.2009;360:1385-94.

Saiki RK, Gelfand DH, Stoffel S, Scharf SJ, Higuchi R, Horn GT, et al. Primer-directed enzymatic amplification of DNA with a thermostable DNA polymerase. Science. 1988 ;239(4839):487-91

Santos, A L F,Derchain, SFM, Calvert, EB, Martins,MB, Dufloth,RM, Martinez, EZ. Desempenho do exame colpocitológico com revisão por diferentes observadores e da captura híbrida II no diagnóstico da neoplasia intra-epitelial cervical graus 2 e 3 . Cadernos de Saúde Pública, 2003;19(4):1029-1037.

Saslow, D, Solomon D, Lawson HW, Killackey M, Kulasingam SL, Cain J et al. Guidelines for the Prevention and Early Detection of Cervical Cancer. Am J Pathol 2012; $137: 516-542$.

Scapulatempo C, Fregnani JH, Campacci N, Possati-Resende JC, Longatto-Filho A; Rodeo Study Team. Rodeo Study Team. The significance of augmented high-grade 
squamous intraepithelial lesion detection on pap test examination: partial results from the RODEO study team. Acta Cytol. 2013;57(5):489-94.

Schiffman MH, Bauer HM, Hoover RN, Glass AG, Cadell DM, Rush BB. et al. Epidemiologic Evidence Showing That Human Papillomavirus Infection Causes Most Cervical Intraepithelial Neoplasia. J Natl Cancer Inst. 1993;85(12):958-64.

Schiffman, M, Wentzensen N, Wacholder S, Kinney W, Gage JC, Castle PE, et al. Human Papillomavirus Testing in the Prevention of Cervical Cancer (Review). J Natl Cancer Inst, 2011;103:368-383.

Schiffman M, Doorbar J, Wentzensen N, de Sanjosé S, Fakhry C, Bradley J. et al. Carcinogenic human papillomavirus infection. Nat Rev Dis Primers. 2016 ;2:16086

Schiller JT, Castellsagué X, Villa LL, Hildesheim A. An update of prophylactic human papillomavirus $\mathrm{L} 1$ virus-like particle vaccine clinical trial results. Vaccine.2008;26S:K53-K61.

Schlecht NF, Platt RW, Duarte-Franco E, Costa MC, Sobrinho JP, Prado JCM, Ferenczy A, Rohan TE, Villa LL, Franco EL. Human Papillomavirus Infection and Time to Progression and Regression of Cervical Intraepithelia Neoplasia. J Natl Cancer Inst. 2003;95:1336-43

Siebers AG, Klinkhamer PJ, Grefte JM, Massuger LF, Vedder JE, Beijers-Broos A. et al. Comparison of liquid-based cytology with conventional cytology for detection of cervical cancer precursors: a randomized controlled trial. JAMA. 2009;302(16):175764.

Snijders PJ1, Verhoef VM, Arbyn M, Ogilvie G, Minozzi S, Banzi R, et al. High-risk HPV testing on self-sampled versus clinician-collected specimens: a review on the clinical accuracy and impact on population attendance in cervical cancer screening. Int J Cancer. 2013;132(10):2223-36

Souza, N. S. T.; Melo, V. H.; Castro, L. P. F. Diagnóstico da infecção pelo HPV em lesões do colo do útero em mulheres HIV+: Acuidade da histopatologia. RBGO. 2001; 23(6):355-361, 2001.

Stanley M, Pinto LA, Trimble C. Human papillomavirus vaccines - immune responses. Vaccine. 2012;30 Suppl 5:F83-7

Steben, M.; Franco, E.D. Human papillomavirus infection: Epidemiology and pathophysiology. Gynecol Oncol. 2007;107(2 Suppl 1):S2-5.

Stoler MH, Castle PE, Solomon D, Schiffman M; et al. The expanded use of HPV testing ingynecologic practice per ASCCP-guided management requires the use of wellvalidated assays. Am J Clin Pathol. 2007;127(3):335-7. 
Stoler MH, Wright TC Jr, Sharma A, Zhang G, Apple R, Wright TL, et al.(Addressing THE Need for Advanced HPV Diagnostics) Study Group. The interplay of age stratification and HPV testing on the predictive value of ASC-US cytology. Results from the ATHENA HPV study. Am J Clin Pathol. 2012;137(2):295-303.

Strauss MJ, Shaw EV, Bunting H, Melnick JL. "Crystaline" virus-like particles form skin papillomas characterized by intranuclear inclusion bodies. Proc Soc Exp Biol Med.1949;72:46-52.

Thomison J 3rd, Thomas LK, Shroyer KR. Human papillomavirus: molecular and cytologic/histologic aspects related to cervical intraepithelial neoplasia and carcinoma. Hum Pathol. 2008;39(2):154-66.

Torres-Ibarra L, Lazcano-Ponce E, Franco EL, Cuzick J, Hernández-Ávila M, Lorincz A, et al. Triage strategies in cervical cancer detection in Mexico: methods of the FRIDA Study. Salud Publica Mex. 2016;58(2):197-210.

Tota JE, Ramana-Kumar AV, El-Khatib Z, Franco EL. The road ahead for cervical cancer prevention and control. Curr Oncol. 2014;21(2):e255-64.

Tozetti IA, Scapulatempo IDL, Kawski VL, Ferreira AW, Levi JE. Multiple types of human papillomavirus in cervical samples in women in Campo Grande, MS, Brazil. BJID. 2006;10(5):309-10.

Tsiodras S, Goegoulakis J, Chranioti A, Voulgaris Z, Psyrri A, Tsivilika A, Panayotides J, Karakitsos P. Hybrid capture vs. PCR screening of cervical human papilloma virus infections. Cytological and histological associations in 1270 women. BMC Cancer. 2010;10:53-60

van Rosmalen J, de Kok IM, van Ballegooijen M. Cost-effectiveness of cervical cancer screening: cytology versus human papillomavirus DNA testing. BJOG. 2012 ;119(6):699-709

Vijayaraghavan A, Efrusy M, Lindeque G, Dreyer G, Santas C . Cost effectiveness of high-risk HPV DNA testing for cervical cancer screening in South Africa. Gynecol Oncol. 2009;112(2):377-83

Villa, L. L.; Denny, L. Methods for detection of HPV infection and its clinical utility. Int J Gynaecol Obstet. 2006; 94: Suppl 1, (S71-S80).

von Knebel Doeberitz, M.; Syrjanen, K. J. Molecular markers: how to apply in practice. Gynecol Oncol. ,2006;103(1):18-20.

von Knebel Doeberitz M, Reuschenbach M, Schmidt D, Bergeron C. Biomarkers for cervical cancer screening: the role of p16(INK4a) to highlight transforming HPV infections. Expert Rev Proteomics. 2012;9(2):149-63. 
Walboomers JM, Jacobs MV, Manos MM, Bosch FX, Kummer JA, Shah KV et al. Human papillomavirus is a necessary cause of invasive cervical cancer worldwide. $\mathbf{J}$ Pathol 1999;189(1):12-9.

Waxman AG, Chelmow D, Darragh TM, Lawson $\quad H$, Moscicki AB. Revised terminology for cervical histopathology and its implications for management of high-grade squamous intraepithelial lesions of the cervix. Obstet Gynecol. 2012;120(6):1465-71

Wentzensen N, Fetterman B, Castle PE, Schiffman M, Wood SN, Stiemerling E. et al. p16/Ki-67 dual stain cytology for detection of cervical precancer in HPV-positive women. J Natl Cancer Inst. 2015;107(12):djv257

Whitlock EP, Vesco KK, Eder M, Lin JS, Senger CA, Burda BU. Liquid-based cytology and human papillomavirus testing to screen for cervical cancer: a systematic review for the U.S. Preventive Services Task Force. Ann Intern Med. 2011;155:687697.

Who - The World Health Organization - Information Centre on HPV and Cervical Cancer (HPV Information Centre). Human Papillomavirus and Related Diseases. Summary Report 2014. Acesso em 01/10/2014. Disponível em: www.who.int/ hpvcentre.

Wilbur DC, Black-Schaffer WS, Luff RD, Abraham KP, Kemper C, Molina JT. et al. The Becton Dickinson FocalPoint GS Imaging System: clinical trials demonstrate significantly improved sensitivity for the detection of important cervical lesions. Am J Clin Pathol. 2009;132(5):767-75.

Wright TC Jr, Stoler MH, Behrens CM, Apple R, Derion T, Wright TL. The ATHENA human papillomavirus study: design, methods, and baseline results.Am J Obstet Gynecol. 2012;206(1):46.e1-46.

Wright TC Jr, Stoler MH, Agreda PM, Beitman GH, Gutierrez EC, Harris JM- et al. Clinical performance of the BD Onclarity HPV assay using an adjudicated cohort of BD SurePath liquid-based cytology specimens. Am J Clin Pathol. 2014;142(1):43-50.

Wright TC Jr, Stoler MH, Aslam S, Behrens CM. Knowledge of Patients' Human Papillomavirus Status at the Time of Cytologic Review Significantly Affects the Performance of Cervical Cytology in the ATHENA Study. Am J Clin Pathol. 2016 ;146(3):391-8.

Zielinski GD, Bais AG, Helmerhorst TJ, Verheijen RH, de Schipper FA, Snijders PJ, et al. HPV testing and monitoring of women after treatment of CIN 3: review of the literature and meta-analysis. Obstet Gynecol Surv. 2004;59(7):543-53.

Zur Hausen H. Condyloma acuminate and human genital cancer. Cancer Research.1976;36: 530. 
10. Apêndice 
Apêndice 1 - Submissão do artigo

Scheluebon venutcripas

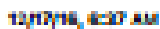

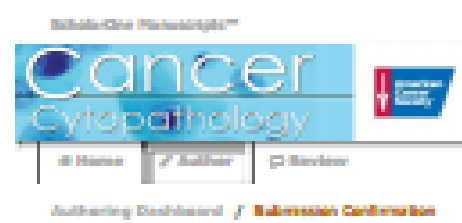

$|\min | \operatorname{mon}|=|$

Submission Confirmation

Thank you for your submission

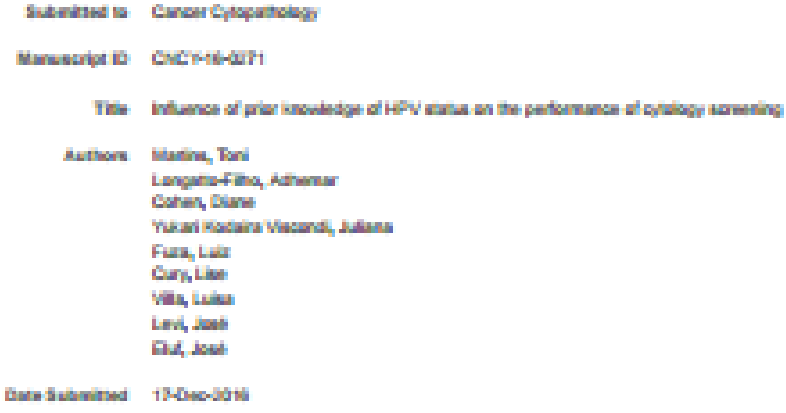

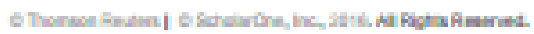

Menche

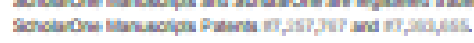

